\title{
A nobreza da República: notas sobre a formação da primeira elite senhorial do Rio de Janeiro (séculos XVI e XVII) ${ }^{1}$
}

\author{
João Fragoso
}

\begin{abstract}
A instalação da economia de plantations no recôncavo do Rio de Janeiro ocorreu sob os auspícios dos bons ventos do mercado internacional. ${ }^{2}$ Tomando por base o ano de 1550 , verifica-se que o preço do açúcar mais que duplica até o final do século. ${ }^{3}$ Segundo Ferlini, tal tendência altista, com algumas baixas eventuais, se manteria ainda na década de $1630 .{ }^{4} \mathrm{Tal}-$ vez seja esta seqüência de boas conjunturas que explique o rápido crescimento do número de engenhos no Brasil da época, e em particular no Rio. Em 1583, o Rio de Janeiro contava com somente três engenhos; em 1612 este número passaria para 14 e dezessete anos depois, para 60 (ver quadro 1). Caso consideremos que em 1680 existiam cerca de 130 fábricas de açúcar, $^{5}$ pode-se afirmar que entre 1612 e 1629 , portanto em apenas 17 anos, foram constituídos 35\% de todos engenhos existentes no recôncavo em finais do século XVII. Número que, se confirmado, apontaria para as primeiras décadas do Seiscentos como decisivas para a montagem da economia escravista e exportadora do Rio de Janeiro.
\end{abstract}

\section{Quadro 1:}

Número de engenhos em Pernambuco, Bahia e Rio de Janeiro, (1583-1629)

\begin{tabular}{lccccc}
\hline Capitanias & $1583(1)$ & $1612(2)$ & $1 / 2 \% *$ & $1629(3)$ & $2 / 3 \%^{*}$ \\
\hline Pernambuco & 66 & 90 & 1.0 & 150 & 3.1 \\
Bahia & 36 & 50 & 1.1 & 80 & 2.8 \\
Rio de Janeiro & 3 & 14 & 5.8 & 60 & 7.9 \\
\hline
\end{tabular}

Fonte: SCHWARTZ, Stuart. Segredos internos, São Paulo: Cia. das Letras/CNPq, 1988. p. 148.

obs.: * taxa de crescimento anual 
Este resultado pode ser confirmado por um outro conjunto de fontes: principalmente as genealogias de Rheingantz ${ }^{6}$ baseadas em registros paroquiais de batismos, casamentos e óbitos; escrituras públicas, e cartas de sesmarias (ver anexo 1). Através do cruzamento destas fontes, é possível identificar a existência de 197 famílias/genealogias que, em algum momento do século XVII, possuíram um ou mais engenhos de açúcar, das quais $61 \%$ tiveram o seu ponto de partida antes de 1620. Antes de continuar, entretanto, permitam-me fazer uma pequena nota para explicar como foi construída a noção de família senhorial.

Rheingnatz organiza as suas genealogias do século XVII a partir dos primeiros casais de povoadores que se tem notícia no Rio de Janeiro. Quando um dos membros destas genealogias — por descendência masculina foi dono de engenhos, considerei como uma família senhorial. Temos nesta situação 197 genealogias/famílias senhoriais. Há, entretanto, casos em que a esposa do casal fundador de uma genealogia é, na verdade, filha ou neta de uma outra família senhorial. Neste caso, e quando o marido não possui ascendentes na Conquista, considerei que tal família descende de uma família senhorial extensa. Portanto, uma família senhorial extensa conteria, em si, mais de uma família senhorial. Trocando em miúdos, em finais do século XVI, chegou ao Rio o casal Miguel Gomes Bravo e Isabel Pedrosa. Várias décadas depois, em uma escritura de dote, temos a grata notícia que Miguel, em algum momento de sua vida, teria sido um feliz proprietário de engenho de açúcar (Ver anexo 1). Esta informação, por conseguinte, transforma tal família em senhorial, já na sua primeira geração. Por seu turno, entre os seus seis filhos, um seria dono de moendas e uma de suas filhas teria se casado com João do Couto Carnide; um estrangeiro no Rio que, em 1632, aparece com uma outra fábrica de açúcar. Com isto, portanto, segundo os meus critérios, a família Gomes Bravo passaria a ser do tipo extensa; nela teríamos duas famílias com moendas. Passadas mais algumas décadas, duas das netas de Isabel voltariam a ter núpcias com pessoas sem parentesco ascendente no Rio (Pantaleão Duarte Velho e Manuel de Gouveia), mas que, igualmente, adquirem engenhos. Assim sendo, ao longo de três geraçôes, nota-se que a família extensa iniciada por Miguel e Isabel reúne quatro famílias senhoriais: além dos Gomes Bravo, 
os Couto Carnides, os Duarte Velho e os Gouveia. As três últimas estavam ligadas entre si pela linha feminina e através desta descendiam da primeira. Por último, utilizei a expressão família extensa senhorial sem nenhuma conotação antropológica, digamos, mais sofisticada. Ela não diz respeito à co-residência de várias gerações de parentes em um mesmo domicílio, às estratégias de casamentos endógenos entre consangüíneos ou às relações de solidariedade familiares. ${ }^{7} \mathrm{Na}$ verdade, com esta noção procurei principalmente identificar a continuidade temporal, via descendência, entre diferentes domicílios e, com isto, perceber um dos mecanismos de formação das fortunas senhoriais. Na verdade, a noção de família extensa para nós é profundamente pragmática, já que ela dá conta de uma situação onde mais de 1/3 das famílias senhoriais saíram de outras com o mesmo status. Dito isto, podemos voltar ao nosso ponto de partida.

Como se observa no quadro 2, ao longo do século XVII, trabalhei com um total de 197 famílias senhoriais. Destas, 32 são extensas e 73 são famílias vinculadas, por linha feminina, com as primeiras. As demais 92, a partir daqui denominadas de famílias senhoriais simples, não possuem vínculos de parentesco, seja do lado masculino ou feminino, com nenhum casal ascendente conhecido na Conquista e, da mesma maneira, também não deram origem, através do casamento de suas filhas ou netas com estrangeiros, a outras famílias senhoriais. Conseqüentemente, tendo em conta suas origens, ao invés de 197 famílias, na verdade, temos apenas 124 famílias.

Passando para o quadro 3, nota-se que destas 124, 52 famílias senhoriais (simples e extensas) ou 58\%, foram formadas até 1620. Entretanto, este resultado se altera completamente quando consideramos que entre aquelas 52 famílias, 27 eram extensas que, por seu turno, ao longo do Seiscentos, dariam origem a outras 68 famílias senhoriais. E, assim sendo, fazendo uma simples conta de somar, temos que, antes de 1621, as bases de 120 famílias senhoriais (ou 61\% de todas as 197 famílias) já estariam presentes no recôncavo do Rio de Janeiro. 


\section{Quadro 2:}

Tipos de famílias senhoriais

\begin{tabular}{lcc}
\hline Tíos & NúMEROS & $\%$ \\
\hline (1) Famílias extensas & 32 & 16.2 \\
(2) Famílias derivadas & 73 & 37.0 \\
por linha feminina das "extensas" & & \\
Famílias simples & 92 & 46.7 \\
$(1)+(2)$ & 105 & 53.2 \\
Totais & 197 & 100.0 \\
\hline
\end{tabular}

Fontes: Anexo 1.

\section{Quadro 3:}

Número de famílias senhoriais ligadas às famílias extensas: $1566-1700$.

\begin{tabular}{l|l|l|c|c|c|c|l}
\hline Períodos & $\begin{array}{l}\text { fam. } \\
\text { sim. (1) }\end{array}$ & $\begin{array}{c}\text { fam. } \\
\text { ext. (2) }\end{array}$ & $(1)+(2)$ & $\%$ & $\begin{array}{l}\text { fam. } \\
\text { der. (3) }\end{array}$ & $(1)+(2)+(3)$ & $\%$ \\
\hline $1566-1600$ & 12 & 14 & 26 & 21.0 & 44 & 70 & 35.5 \\
$1566-1620$ & 25 & 27 & 52 & 42.0 & 68 & 120 & 61.0 \\
$1621-1700$ & 67 & 5 & 72 & 58.0 & 5 & 77 & 39.0 \\
$1566-1700$ & 92 & 32 & 124 & 100.0 & 73 & 197 & 100 \\
\hline
\end{tabular}

Obs.: fam. sim. = familia senhorial simples; fam. ext. = familia senhorial extensa; fam. der. = familias senhoriais derivadas por linha feminina das "extensas".

Fonte: Anexo1.

Portanto, através dos quadros 1 e 3 , infere-se que àquilo que poderíamos chamar de acumulação primitiva, origem da economia de plantation do Rio de Janeiro e da sua elite senhorial, ocorreu entre 1566 e 1620. Numa época, portanto, em que dificilmente tal região poderia ser caracterizada como uma área açucareira, ou mesmo baseada na escravidão de africanos. Para tanto, basta recordar que, ainda em 1612, o recôncavo possuía somente 12 engenhos de açúcar. Diante de tais números, caberia perguntar em que 
cenário econômico ocorre tal acumulação, ou mais precisamente: quem pagou as suas contas?

Já vimos que os ventos que sopravam no mercado internacional para o açúcar eram bons. Contudo, só isto não bastava. Para se aproveitar as boas oportunidades, como se sabe, é necessário ter recursos e crédito. Neste sentido, as notícias que vinham de Lisboa e de seu império ultramarino não eram as melhores.

\section{As conjunturas do Império e do Atlântico}

O início da montagem da sociedade colonial no Rio de Janeiro, deuse em um ambiente caracterizado por Vitorino Magalhães Godinho como de viragem estrutural do império ultramarino português. A partir de meados do século XVI, o império luso passaria, com intensidade cada vez maior, a ser atacado nas suas diversas fronteiras: do Marrocos, passando por Ormuz, até a Insulíndia. ${ }^{8}$ De resto, em finais do século XVI, para o Estado da Índia, o futuro também não parecia nada promissor. Além da queda das receitas da rota do Cabo, da expansão dos Otomanos, dos mongóis e dos Safávidas do Irã, após a União Ibérica, teríamos o crescimento da presença dos holandeses na Ásia portuguesa. ${ }^{9}$

Diante de tal quadro, já em 1548, a Coroa decidiria fechar a sua feitoria em Antuérpia, marcando com isto o recuo do Estado na economia e o avanço de poderosos banqueiros-mercadores transnacionais, aliados à nobreza portuguesa. ${ }^{10}$

Os efeitos desta viragem sobre a sociedade portuguesa são facilmente entendidos quando lembramos que, desde o último quartel do século XV, o Estado tinha as suas bases no tráfico ultramarino. Em 1506, cerca de 65\% de suas receitas eram originárias destes tratos. Na verdade, toda a sociedade do Antigo Regime português dependia, direta ou indiretamente, do império comercial; cabe ainda recordar que a Coroa, através de diversas rubricas, passava para as principais casas senhoriais parte do rendimentos ultramarinos. ${ }^{11}$ Neste sentido, não é de se estranhar certa coincidência entre as desventuras do ultramar e de sua metrópole. Entre 1557 e 1607, a dívida interna do Estado cresceria em 250\%. ${ }^{12}$ Ao longo do século XVI, o preço 
do trigo vendido em Lisboa aumentaria em mais de $800 \%$, o que iria se traduzir em fomes freqüentes. ${ }^{13}$ Coroando estes cenários de penúrias, desde as últimas décadas do quinhentos, Portugal seria visitado por crises de mortalidade recorrentes. ${ }^{14}$

Contrabalançando tais azares, como já insinuei, temos os bons ventos do Atlântico Sul. Além da alta do açúcar, a população da América lusa passaria de 6.500 pessoas em $1546-48$ para 150.000 habitantes no final do século. ${ }^{15}$ Apesar do predomínio do gentio da terra nas plantações de Pernambuco e da Bahia, ${ }^{16}$ desde as últimas décadas do quinhentos o tráfico atlântico de escravos já está em franco funcionamento. Só no porto de Luanda, estima-se que as exportações de cativos tenham passado de uma média anual de 2.600 pessoas em 1575-1587, para 5.032 entre 1587 e $1591 .{ }^{17}$

A partir destas últimas informações não é de se estranhar, em meio ao reinado de D. Sebastião, a existência de discussões sobre em quais alicerces o império ultramarino deveria se basear prioritariamente: se na Índia ou no Atlântico (Brasil e África). Nas Cortes de 1562-63 já se considerava: "mais justa, e mais conveniente, a conquista de África, que a da Índia; e a razão era, porque esta estava muito longe, e não rendia coisa, que com ela se não tornasse a gastar, e aquela estava perto". Neste contexto, percebe-se uma atlantização cada vez maior da política ultramarina, e sob as ordens do Desejado, seriam tomadas medidas para aprofundar a presença lusa em Angola e na América portuguesa. ${ }^{18}$

Entretanto, apesar de tais projetos de atlantização do império e da decadência da Ásia portuguesa, esta última, mesmo em 1619, correspondia a mais de $40 \%$ das receitas da coroa portuguesa e o Atlântico apenas $11 \% .{ }^{19}$ Portanto, o Brasil ainda não cumpria o seu papel de base no ultramar, como o fará no século XVIII.

Em suma, mesmo considerando que aquela viragem estrutural significou também o boom do açúcar brasileiro, percebe-se que as três primeiras décadas coloniais do Rio de Janeiro foram marcadas por um império e uma metrópole às voltas com problemas militares e financeiros. Seria neste ambiente nada auspicioso que se daria a acumulação primitiva da economia da plantation e o ponto de partida de $60 \%$ da elite senhorial do Rio de Janeiro seiscentista (ver quadro 3). Ambiente que fica ainda mais angustiante quando passamos para as origens dos conquistares, cujos descendentes 
se transformaram nas melhores famílias da terra, ou seja, se converteram em senhores de engenhos.

Alguns destes conquistadores vieram do norte de Portugal e das Ilhas do Atlântico, como Jordão Homem da Costa e Belchior Pontes. Outros, como Antônio de Mariz e Antônio Sampaio, antes de chegarem ao Rio, passaram primeiro por São Vicente. No século XVI, as pressões demográficas, as dificuldades de acesso à terra e, conseqüentemente, a recorrência das crise de subsistência, transformaram a região de Entre Douro e Minho numa área assolada pela pobreza e, por conseguinte, caracterizada pela continua "fuga de gentes". Fugas, primeiro, em direção das ilhas do Atlântico, e, logo em seguida, para outras partes do império, em especial, o Brasil. ${ }^{20} \mathrm{Em}$ finais do quinhentos, Madeira e os Açores também já não eram as ilhas mais prósperas do além-mar. Para Vieira, a primeira ilha, desde a segunda década do século XVI, vinha perdendo "gentes" em função do definhamento da produção local de cana-de-açúcar, e a segunda, desde meados do mesmo século estava às voltas com a falta de cereais (menos intenso na ilha de São Miguel), ou seja, ambas "exportavam” seus habitantes em razão dos seus processos de penúria. ${ }^{21}$ Quanto a São Vicente, sabe-se que a capitania, em finais do quinhentos, não era o melhor exemplo de riqueza e prosperidade, ou ainda não tinha se transformado no "celeiro do Brasil", cultivado por vastos plantéis de gentios da terra. ${ }^{22}$

No que diz respeito à origem social dos conquistadores do Rio de Janeiro, antes de mais nada, é bom lembrar alguns fenômenos. Entre eles o fato de que, a princípio, a grande aristocracia titulada considerava que as suas obrigações militares paravam no Marrocos. Ao sul do Marrocos, os principais agentes da coroa eram da pequena nobreza. No Oriente, os fidalgos velhos e ricos se recusavam inicialmente a ir "porque a Índia fora descoberta para comércio e trato”. Este quadro só começaria a se alterar, principalmente em relação aos filhos segundos desta aristocracia (aqueles que, conforme o sistema de herança, seriam preteridos dos bens e direitos da casa) com a militarização crescente do Estado da Índia, como forma de assegurar o comércio asiático. ${ }^{23}$ Deste modo, é pouco provável que os Grandes de Portugal tenham, antes de 1620, conhecido a baía de Guanabara. É mais provável que os fidalgos conquistadores tivessem o perfil de João Pereira de Souza Botafogo ou do madeirense Diogo Lobo Teles. João era ori- 
ginário de uma casa nobre de Elvas (sul de Portugal), cujos bens e direitos foram confiscados por ordem régia. Em "desgraça”, João migrara da metrópole, beneficiado por uma determinação da rainha Catarina que "deixava passar em paz aos criminosos que vinham à conquista dos índios bárbaros do Brasil”. ${ }^{24}$ Já Diogo era neto, por parte de mãe, de Vasco Martins Moniz, que se transformara em fidalgo da casa do rei, em função de sua participação nas campanhas da África. ${ }^{25}$ Neste sentido, o avô de Diogo se tornara cavaleiro numa época em que a concessão deste título proliferava e, portanto, aos olhos da melhor aristocracia do reino, se aviltava. ${ }^{26}$

Curiosamente, somente São Vicente talvez tenha fornecido ao Rio um grupo de conquistadores cuja origem social era de uma elite social. Das primeiras 52 famílias originais do Rio de Janeiro (ver quadro 3), pelo menos oito vieram do planalto paulista. Entre elas temos genros e filhos de capitães-gerais daquela capitania, como Manuel Veloso Espinha, genro do capitão Braz Cubas, tendo também por titulares sertanistas como Roque Barreto e André de Leão. Oriundos, portanto, de algumas das "melhores famílias" vicentinas da época, todos também estavam ligados à procura de metais e ao comércio de gentios da terra. ${ }^{27}$ Este fenômeno insinua a possibilidade do negócio vicentino de apresamento de índios ter contribuído para o acúmulo de recursos para a primeira elite senhorial do Rio e, ainda, ter abastecido de escravos "da terra" os primeiros engenhos do Rio de Janeiro. Aquelas oito famílias, ao longo do Seiscentos, se transformariam em 48 famílias senhoriais, ou seja, cerca de $25 \%$ do total conhecido para o século. Cabe ainda destacar que tais ligaçóes ultrapassariam o ano de 1620. Mesmo depois desta data é, ainda, possível verificar casamentos entre filhos de "ministros" vicentinos com membros das famílias senhoriais do Rio.

Por conseguinte, seriam estes homens que fogem da pobreza, procedentes da pequena fidalguia ou egressos da elite de uma capitania pobre que dariam origem às melhores famílias do Rio de Janeiro. Neste sentido, persiste a pergunta inicial de como se pagou a conta da montagem da economia colonial do Rio de Janeiro.

\section{A primeira elite senhorial do Rio}

Segundo Celso Furtado, em texto publicado em 1959 e hoje um clássico da historiografia colonial brasileira, caberia aos holandeses o custeio 
da empresa açucareira. Afirma o autor: "Parte substancial dos capitais requeridos pela empresa açucareira viera dos Países Baixos. (...) Tudo indica que capitais flamengos participaram no financiamento das instalações produtivas no Brasil bem como no da importação da mão-de-obra escrava”. Cerca de trinta anos depois, Schwartz escreveria que, para a Bahia de 1580, cerca de 1/3 dos engenhos eram de propriedade de antigos comerciantes. Não tenho condiçôes e, nesse momento, nem interesse em verificar tais hipóteses para o Nordeste açucareiro. Contudo, em ambos os casos, algo me chama a atenção: para os dois autores, o financiamento da montagem das primeiras plantations seria originário de uma acumulação mercantil, ou seja, do comércio. ${ }^{28}$

Esta hipótese parece ser tentadora para o Rio de Janeiro, já que, na virada do século XVI para o XVII, esta cidade é, em geral, conhecida pela historiografia como uma área de ligação comercial para a Bacia do Prata. O Rio de Janeiro, nas primeiras décadas do século XVII, surgiria como uma região produtora de aguardente e farinha de mandioca, produtos que serviriam de escambo para a aquisição dos cativos africanos, parte dos quais enviados para o Prata. ${ }^{29}$

Entretanto, antes de comentar a hipótese de que os recursos para a montagem dos engenhos do Rio sairiam do comércio, permitam-me fazer um pequeno parênteses para discutir um outro tema: o Rio de Janeiro como região de engenhos de aguardente. ${ }^{30}$ Parece-me, a princípio, um pouco exagerada tal caraterização. Apesar de, ainda em 1695, numa carta do senado do Rio, afirmar-se que "o unico produto que contavam [os do Rio de Janeiro] para a compra de escravos em Angola era a aguardente da terra, cachaça", 31 há várias outras notícias indicando que, junto à cachaça, o açúcar era o principal gênero da região. Para tanto, basta lembrar, como ainda veremos, as várias e acirradas discussões entre senhores locais e comerciantes, sobre o preço do produto-rei, ou as lutas dentro da elite local pelo controle da balança que pesa "as caixas de asucar que se embarcam daqui para Portugall". Numa carta coeva pode-se ler que uma das razões para a baixa dos dízimos reais em 1657, era a queda do preço do açúcar que "é fruto da terra donde se tira o lucro que os que lançam no dito contrato [dizimos] pretendem"; 32 resumindo, o principal lucro dos arrematadores dos dízimos vinha do açú- 
car. De qualquer forma, aguardente ou açúcar, o fato é que, ao longo do século, temos senhores de engenho como Salvador Correia de Sá e Benevides que, em 1642, segundo os seus inimigos, teria mais de 700 negros da Guiné em suas propriedades; ${ }^{33} \mathrm{D}$. Feliciana de Pina que contaria com 91 cativos em 1656; Pedro de Souza Pereira, com 70 escravos em 1673; ou João Dique, com 90 cativos em 1712. Estes números insinuam que, ao longo do século XVII, teríamos uma elite à frente de uma economia de plantation. $^{34}$

Voltando à hipótese de que o comércio Rio do Prata-Rio de JaneiroAngola seria o ponto de partida da empresa açucareira do Rio de Janeiro, esta idéia poderia ser confirmada pela freqüência de contratos e procurações existentes no livro do primeiro oficio de notas para 1612-13, feito para negócios no Rio da Prata. Entretanto, apesar de tentadora deve-se ter alguns cuidados com tal idéia. Antes de mais nada, não se pode perder de vista o caráter incipiente do núcleo urbano e do grupo mercantil do Rio seiscentista, pelo menos em relação ao que a cidade será em princípios do século XIX. Façamos algumas comparações. Nos períodos 1610-13 e 163036, no primeiro ofício de notas da cidade, foram negociadas cerca de 75 escrituras de compra e venda, cujo valor total chegou até nós. Nestas, pouco mais de $70 \%$ dos valores transacionados, estavam ligados a negócios rurais (engenhos, terras, partidos de cana, entre outros). Este número indicaria a pequena expressão das operações urbanas e, mais precisamente, daquelas ligadas ao capital mercantil (navios, lojas, estoques de mercadorias e outros). Séculos mais tarde, quando o Rio já se apresentava como a principal praça mercantil do Atlântico Sul, possuindo uma forte comunidade de negociantes de grosso trato, tal número será bem diferente. Em dez anos, entre 1800 e 1816, nos quatro cartórios da praça, foram negociadas 3.562 escrituras. Nestas, os negócios mercantis representaram 37,8\% de seus valores, as operações com prédios urbanos $29 \%$ e os negócios rurais apenas $21 \%$. Parece-me, pois, desnecessário insistir muito sobre o significado desta comparação: tais números falam por si mesmos. ${ }^{35}$

Apesar do Rio, em princípios do século XVII, não poder ser caracterizado como um exemplo de uma típica cidade mercantil, não há por que deixar de lado as possibilidades do comércio. Afinal, como demonstra uma tese de doutoramento recente, no Portugal dos séculos XVI e XVII, o exercí- 
cio da mercancia não era o monopólio de um único grupo, no caso os mercadores. Ao lado destes, "a nobreza, os militares, os oficiais do rei e o próprio clero, para não falar dos marinheiros e capitães dos navios, exercem a mercancia" ${ }^{36}$ Não há razão para que isto tenha sido diferente em um império ultramarino que, por excelência, era mercantil. Como diria um membro do Conselho Ultramarino, em 1668, quem vai para as Conquistas vai para negociar.

Ao passar para o quadro 4, percebe-se que, além de comerciantes, lavradores, pecuaristas e outros, a primeira elite senhorial do Rio descendia de pessoas ligadas a outras esferas da vida pública, no caso à administração da própria vida pública. Pelo quadro 4 vê-se que 40 famílias, 1/3 de todas as que, ao longo do século XVII, se converteram em donas de engenhos de açúcar, tiveram por origem ministros ou oficiais do rei. Eram provedores da fazenda, escrivães da alfândega, capitães-de-infantaria ou governadores. Se eles eram também comerciantes ou não, no momento, é uma informação que me foge. O certo é que eles eram pessoas a serviço de sua Majestade, e como tal, tinham por função administrar a coisa pública nos trópicos. Mas vejamos um pouco mais o significado destes números.

\section{Quadro 4:}

\section{Períodos de instalação no Rio de Janeiro de famílias senhoriais formadas a partir de Ministros e Oficiais ${ }^{37} 1566-1700$.}

Cargos e número de famílias senhoriais

\begin{tabular}{lllllllllll}
\hline Períodos & A & B & C & D & E & F & A-F & \% TOT. & G & TOT. \\
\hline $1566-1600$ & 1 & 7 & 5 & 5 & 1 & & 19 & 70.8 & 7 & 26 \\
$1566-1620$ & 2 & 8 & 5 & 8 & 2 & & 25 & 48.1 & 27 & 52 \\
$1621-1700$ & & 1 & 3 & 1 & 6 & 4 & 15 & 26.3 & 57 & 72 \\
$1566-1700$ & 2 & 9 & 8 & 9 & 8 & 4 & 40 & 32.3 & 84 & 124 \\
\hline
\end{tabular}

Legenda:

a-Governador.

b-Provedor da Fazenda Real, Ouvidor, Provedor dos Defuntos e Ausentes e Juiz de

Orfãos.

c-Capitão-Mor, Sargento-Mor e Alcaide. 
d- Capitão de Infantaria.

e-Escrivão da Ouvidoria, Escrivão da Provedoria e Almoxarifes.

$f$-Tabelião.

g-Sem ascendência de Ministros e Oficiais.

tot. $=$ total

Fonte: Anexo 1.

No quadro 4, preocupado com a origem ou ponto de partida das famílias senhoriais, utilizei o mesmo procedimento visto no quadro 3. Isto é, as famílias senhoriais extensas, as que têm a capacidade de gerar no tempo outras com o mesmo estatuto, foram tratadas da mesma maneira que aquelas que não possuíram esta capacidade. Assim sendo, as famílias extensas (mesmo contendo em si outras famílias com engenhos) tiveram o mesmo peso numérico que as simples. Dito isto, temos que aquele total de 124 famílias senhoriais, em realidade, corresponde a 197 e as 40 derivadas de funcionários a 89. Explicando melhor: das 40 famílias descendentes de funcionários 24 são senhoriais "simples" e 16 extensas que contém, em si, outras 49 famílias com moendas - fazendo uma simples conta de soma $(24+16+49)$ temos 89 famílias cuja origem fora um ministro ou um oficial da coroa.

Tendo em conta tais informações, passemos para o quadro 5. Nele se verifica, antes de mais nada, que 45\% de todas as 197 famílias senhoriais seiscentistas têm como ponto de partida homens de sua Majestade. Além disso, é possível observar que mais da metade dos senhores de engenho do Seiscentos eram empregados da coroa, ou deles descendiam, ou ainda estavam casados com descendentes de ministros do Reino. Isto significa afirmar que este tipo de família é a que tem a maior capacidade de reproduzir donos de moendas na Colônia.

\section{Quadro 5:}

\section{Famílias senhoriais e senhores de engenho}

\begin{tabular}{lllll}
\hline FAM. SR. & $\begin{array}{l}\mathrm{N}^{\mathbf{0}} \text { DE FAMÍlIAS } \\
\text { SENHORIAIS }\end{array}$ & \% DE (A) & $\begin{array}{l}\mathrm{N}^{\mathbf{0}} \text { DE } \\
\text { SENHORES }\end{array}$ & \% DE (A) \\
\hline Ministros & 89 & 45.2 & 155 & 52.5 \\
Outras & 108 & 58.2 & 140 & 47.5 \\
Totais (a) & 197 & 100 & 295 & 100 \\
\hline
\end{tabular}

Fonte: Anexo 1. 
Passando para o quadro 6, constata-se também que este mesmo tipo de família é mais estável no tempo. Para isto, considerei o número de gerações com senhores de engenho que uma família é capaz de ter, a partir de seu casal fundador. Entre 1565 e 1600, desembarcam no Rio 26 futuras famílias senhoriais. Destas, mais da metade só teria uma ou duas gerações de donos de moendas até 1700 e menos de $1 / 4$ com quatro gerações. Para aquelas que não descendem de ministros, os resultados são mais precários. De um total de sete famílias, quatro só conseguem conviver com engenhos em uma geração, e apenas uma família chega à marca de três vidas. Algo bem diferente ocorre quando passamos para os descendentes dos "filhos dos homens do rei”. Para estes, de uma amostragem de 19 casos, mais da metade consegue ultrapassar a marca de 3 gerações. Na verdade, durante o período considerado, estas últimas famílias são as únicas com quatro gerações de senhores. Considerando que encontramos resultados semelhantes para todo o século XVII, pode-se afirmar que as famílias que descendem dos ministros e oficiais constituem o esteio da elite senhorial do Rio de Janeiro, ou seja, elas materializam a continuidade temporal do grupo de senhores de engenho.

\section{Quadro 6:}

\section{Número de gerações de senhores de engenho nas famílias com ministros}

\begin{tabular}{|c|c|c|c|c|c|c|c|c|c|c|}
\hline & $\begin{array}{l}\# \\
4\end{array}$ & $\%$ (a) & 3 & $\begin{array}{l}\text { e } \\
\%(a)\end{array}$ & $\begin{array}{l}\mathrm{g} \\
2\end{array}$ & $\begin{array}{l}\text { e r } \\
\%(a)\end{array}$ & $1^{a}$ & $\begin{array}{c}\text { ç } \\
\%(a)\end{array}$ & о & $\begin{array}{l}\text { e } \quad \begin{array}{l}\text { s } \\
\%(a)\end{array}\end{array}$ \\
\hline Ministros & 6 & 31.6 & 4 & 21.0 & 4 & 21.0 & 5 & 26.3 & 19 & 99.9 \\
\hline Outros & 0 & & 1 & 14.3 & 2 & 28.6 & 4 & 57.1 & 7 & 100.0 \\
\hline $1566-1600$ (a) & 6 & 23.1 & 5 & 19.2 & 6 & 23.1 & 9 & 34.6 & 26 & 100.0 \\
\hline Ministros & 6 & 15.0 & 6 & 15.0 & 8 & 20.0 & 20 & 50.0 & 40 & 100.0 \\
\hline Outros & 0 & 0 & 4 & 4.8 & 22 & 26.2 & 58 & 69.0 & 84 & 100.0 \\
\hline $1566-1700(a)$ & 6 & 4.8 & 10 & 8.1 & 30 & 24.2 & 78 & 62.9 & 124 & 100.0 \\
\hline
\end{tabular}

Fonte: Anexo 1.

Observa-se no quadro 7 que metade das 32 famílias extensas existentes no Rio são oriundas de funcionários do rei. Sendo que estas últimas 
teriam a capacidade de produzir outras 49 unidades senhoriais, o que significa $2 / 3$ do total das 73 famílias criadas nestas condições.

\section{Quadro 7:}

Número de famílias senhoriais criadas a partir de famílias extensas com fundador ministro ou oficial do rei; (1566-1700)

\begin{tabular}{lcccc}
\hline & FAM. EXTENSAS & \% DE (A) & FAM. SR. & \% DE (A) \\
\hline Ministros & 16 & 50.0 & 49 & 67.1 \\
Outros & 16 & 50.0 & 24 & 32.9 \\
Totais (a) & 32 & 100.0 & 73 & 100.0 \\
\hline
\end{tabular}

Fonte: Anexo 1.

Esta última informação ganha especial relevo quando recordamos (quadro 2) que, das 197 famílias senhoriais conhecidas no Seiscentos, 73 ou $37 \%$ derivavam por linha feminina de outras 32 famílias. Assim, temos um conjunto de 105 famílias senhoriais $(32+73)$, onde cada uma estava ligada por relações de parentesco com, pelo menos, outra família. Este último número, por representar mais da metade das 197 famílias conhecidas, enfatiza as relações de parentesco existentes no interior da elite e, além disso, evidencia que uma das vias de acesso a este grupo era através do casamento, com moças de famílias senhoriais já estabelecidas. $\mathrm{O}$ casamento para o noivo-estrangeiro representava não só a possibilidade de ter acesso a um dote, mas também a todo um sistema de alianças e solidariedades presente na elite colonial.

Sendo isto verdade, pelo quadro 7 , parece que as meninas das famílias descendentes de ministros eram as que tinham maior sucesso entre os pretendentes a senhor no Rio de Janeiro. Afinal, daqueles 73 casos 49 foram casamentos com noivas filhas ou netas de oficiais do rei. Por seu turno, interpretando este mesmo número do lado dos pais e/ou avós das referidas noivas, infere-se que os ministros e descendentes controlavam o acesso dos cadetes à elite. 
Em resumo, as famílias senhoriais derivadas de ministros e oficiais do rei são as que possuem, no correr do Seiscentos, o maior número de senhores de engenho, a maior estabilidade no tempo, a maior capacidade de gerar outras famílias senhoriais e, portanto, são as que têm maior capacidade de absorção de estrangeiros. Este conjunto de traços transforma, a meu ver, tais famílias no núcleo principal da primeira elite senhorial do Rio de Janeiro. Dito isto, recuperemos rapidamente o quadro 3. Nele se viu que entre 1566 e 1620 já estavam devidamente presentes no Rio de Janeiro, no recôncavo, as bases de 120 ou 61\%, das 197 famílias conhecidas no século XVII. Através do quadro 8, percebe-se que daquelas 120 famílias, 73 tiveram por origens ministros do rei. A partir de tal constatação, podemos nos aproximar mais do cenário da montagem da economia de plantations e de sua elite e começar a identificar melhor os mecanismos pelos quais tal sociedade fora articulada.

\section{Quadro 8:}

\section{Famílias extensas de ministros e suas famílias senhoriais: 1566-1700}

\begin{tabular}{l|c|c|c|c|c|c|c|c}
\hline & $\begin{array}{c}\text { fam. } \\
\text { sim (1) }\end{array}$ & $\begin{array}{c}\text { fam. } \\
\text { ext. (2) }\end{array}$ & $\begin{array}{c}\text { fam. } \\
\text { der (3) }\end{array}$ & $\begin{array}{c}(1+2 \\
+3)\end{array}$ & $\%$ de (a) & $\%$ de (b) & $\begin{array}{c}\text { outras } \\
\text { fam. }\end{array}$ & Totais (b) \\
\hline $1566-1620$ & 10 & 15 & 48 & 73 & 82.0 & 60.8 & 47 & 120 \\
$1621-1670$ & 14 & 1 & 1 & 16 & 18.0 & 20.8 & 61 & 77 \\
$1566-1700(a)$ & 24 & 16 & 49 & 89 & 100.0 & 45.2 & 108 & 197 \\
\hline
\end{tabular}

obs: ver quadro 3.

Fonte: Anexo 1.

Em outras palavras, se é certo que a acumulação primitiva — ou algo que o valha - da economia colonial do Rio acontece no cenário da virada do século XVI para o XVII, talvez também seja certo que a formação da primeira elite senhorial se identifique com a posse dos cargos da administração pública — aí se incluem também os postos no senado da câmara nas mãos de determinadas famílias. Na administração da coisa pública, terse-ia também administrado a construção da referida elite. 
Vejamos como tudo começou, e um pouco mais sobre as famílias que ocupariam os cargos de sua Majestade.

"Fundada pois a cidade [Rio de Janeiro em 1565] pelo governador Mem de Sá em o dito outeiro, ordenou logo que houvesse nela oficiais e ministro da milícia, justiça e fazenda" ${ }^{38}$ Como se percebe por esta passagem de Frei Vicente do Salvador, uma das primeiras medidas tomadas por Mem de Sá, após a efetiva conquista do Recôncavo do Rio de Janeiro, foi a instalação de uma administração civil e militar, de modo a viabilizar a ocupação e a colonização da região.

Conforme o organograma administrativo-político da época, a autoridade máxima militar e civil da capitania estava nas mãos do Governador. Designado pelo rei, entre os seus atributos estava a possibilidade de distribuir sesmarias e indicar pessoas para outros postos da administração, embora a confirmação coubesse à coroa. O poder do governador do Rio, em 1608, seria ampliado através da criação da Repartição Sul. Por esta medida, o Rio adquiria maior autonomia frente ao Governo Geral e ainda recebia a jurisdição das capitanias de São Vicente e do Espírito Santo. ${ }^{39}$ Após a retirada de Mem de Sá, o escolhido para tal cargo, em 1568, foi o seu sobrinho, Salvador Correia de Sá. A família Correia de Sá dispensa maiores comentários; basta lembrar que ela ocuparia aquele cargo, com alguns intervalos, por 55 anos entre 1568 e 1700. Ao longo deste período, ela teria, entre efetivos e interinos, seis governadores ${ }^{40}$ e pelo menos 12 senhores de engenho, o que a transforma numa das poucas famílias com, pelo menos, um dono de moendas em todas as suas gerações seiscentistas.

Abaixo do governador na hierarquia de mando da capitania, encontramos o ouvidor, o alcaide-mor e os provedores da fazenda real, postos que eram ocupados por nomeaçôes do rei. Cabia ao primeiro "ministrar a justiça”. Com a criação da Repartição Sul, o ouvidor-geral do Rio passava a ser a instância imediatamente superior aos demais ouvidores e dos juizes ordinários das capitanias pertencentes a dita Repartição. Em 1568, este cargo seria dado em serventia por três anos a Cristóvão Monteiro, genro de Jorge Ferreira Bulhões, capitão-mor vicentino. Terminada esta serventia, em 1572, o posto de ouvidor passaria, nos três anos seguintes, para Francisco Dias Pinto, antigo capitão da capitania de Porto Seguro e, desde 1565, 
proprietário do ofício de alcaide-mor do Rio de Janeiro e, como tal, encarregado da defesa militar da cidade. Dos casamentos dos descendentes de Jorge Ferreira e Francisco Dias sairia, no Rio, a família senhorial extensa Castilho Pinto. ${ }^{41}$

Quanto ao posto de provedor da fazenda, ele era exercido em conjunto com o de juiz da alfândega. A pessoa que ocupasse esta posição teria a responsabilidade de resguardar os interesses da fazenda real e, em particular, supervisionar a arrecadação dos dízimos reais e a alfândega. ${ }^{42}$ No ano de 1568, estas funções estavam sob a guarda de Antônio de Mariz Loureiro. Como os demais acima, em meio às lutas de conquista da América lusa, Antônio fora armado cavaleiro fidalgo da Casa Real e, também como outros fundadores de famílias senhoriais de sua geração, ocuparia diversos postos na administração colonial. ${ }^{43}$ Do casal formado por Antônio e sua esposa Isabel, até o final do século XVII, sairiam 10 famílias senhoriais e 18 senhores de engenho.

Subordinados a estes ministros temos, entre outros, diversos tipos de escrivães e meirinhos; e, na área militar, os capitães-de-fortaleza, de infantaria e os alferes.

Havia, entretanto, alguns postos estratégicos que controlavam as chaves daquilo que poderíamos chamar, mesmo caindo em anacronismo, de poupança social. Refiro-me ao conjunto de funçôes que davam acesso à cobrança e guarda dos impostos e aos bens dos órfãos da capitania. Neste caso, além do provedor da fazenda, figuravam o escrivão da fazenda, o almoxarife, o escrivão do almoxarife e alfândega e o juiz dos órfãos. Entre os primeiros escrivães da fazenda da capitania, em 1596, encontramos Baltazar da Costa, genro do capitão dos descobrimentos, João Pereira de Souza Botafogo. Ao que parece, este ofício logo se transformaria em propriedade desta família. Em 1655, o filho de Baltazar, Francisco da Costa Barros, afirmava que, desde 1630 , exercia aquele ofício. ${ }^{44} \mathrm{Da}$ família extensa Botafogo sairiam outras três famílias senhoriais. Quanto ao juizado de órfãos, este posto, em 1584, era ocupado por Antônio de Mariz e, anos mais tarde voltaria a ser encabeçado por seu filho Diogo de Mariz. ${ }^{45}$ Depois de 1644, tal ofício passaria como propriedade para a família Telles de Menezes. Cabia ao titular do juizado a responsabilidade de olhar pelos órfãos 
e, em especial, a arca dos órfãos, o cofre onde era guardado todo o dinheiro, as dívidas ativas e os rendimentos das fazendas herdados dos pais falecidos. ${ }^{46}$

Entre os capitães-de-infantaria que chegaram ao recôncavo do Rio de Janeiro com Mem de Sá, encontrava-se Antônio Sampaio. ${ }^{47}$ Ele, juntamente com sua esposa, Maria Coelha, dariam origem a quatro gerações de senhores de engenho até finais do Seiscentos.

Os exemplos acima ilustram o que já podia ser visto no quadro 4, ou seja, uma parte significativa da primeira elite senhorial do Rio de Janeiro eram os conquistadores e, por conseguinte, pertenciam às expedições comandadas por Mem de Sá nas lutas contra os franceses e tamoios. Em um segundo momento, estes mesmos homens seriam investidos na condição de primeira elite administrativa e militar da capitania. Isto é, passariam a ocupar postos cuja função era viabilizar a presença lusa no recôncavo ou, o que é o mesmo, montar a sociedade colonial na região. Desde já, cabe lembrar que tal metamorfose de conquistadores em administradores e na primeira elite colonial, em si, não é muita novidade na história da conquista ibérica do Novo Mundo. Em realidade, o mesmo fenômeno é presenciado no México de Cortez, e no Peru, com Pizarro. ${ }^{48}$

No caso do Rio de Janeiro, esta metamorfose é ainda mais reforçada, quando se percebe que ela é acompanhada de dois outros movimentos. $\mathrm{O}$ primeiro diz respeito às alianças políticas, via casamentos, que desde cedo vão existir entre estes conquistadores/ministros. Antônio de Mariz teve cinco filhos que chegaram à idade de casamento: três rapazes e duas moças. Todos se casaram, sendo que quatro dos rebentos com pessoas especiais. O mais velho, por exemplo, o senhor de engenho e provedor da fazenda (em 1606) Diogo Mariz, contrai bodas com Paula de Rangel, filha de Julião Rangel, membro da expedição de Mem de Sá, antigo Ouvidor da Cidade e escrivão dos órfãos. Além disso, o irmão de Paula, desde 1620, era alferes da fortaleza de Santa Cruz e guarda dos navios. ${ }^{49}$ A família extensa de Julião contou com quatro famílias senhoriais. Dois outros filhos de Antônio casaram-se com famílias que teriam ocupado a provedoria da fazenda real e uma de suas filhas com o ouvidor da cidade, Tomé de Alvarenga, em 1603. Deste último matrimônio, uma das netas de Antônio, Maria de Alvarenga, tempos depois tornar-se-ia esposa de Manuel 
Correia, irmão do governador Salvador Correia de Sá. Manuel e Maria seriam os pais do futuro governador da cidade, Tomé Correia de Alvarenga. Algo semelhante pode ser encontrado em outras famílias extensas.

O segundo movimento acima referido diz respeito ao fato destes conquistadores e seus filhos, entre o exercício de um e outro posto na administração imperial, também teream ocupado postos no senado da câmara. Isto é, eles também estavam presentes em outro cenário da administração pública do poder, o senado da câmara. Cabia ao senado garantir o bem estar da República e isto, entre outras coisas, significava fiscalizar o abastecimento da cidade (preços e qualidade dos gêneros), intervir na fixação dos preços, administrar impostos etc. Em suma, cabia a ele, em nome dos interesses da República, intervir no mercado.

Através do quadro 9, nota-se que entre 1565 e 1620, de um total de 107 oficiais da câmara, 62, ou quase 60,0\% eram antigos ministros da administração imperial — alguns inclusive acumulavam os dois cargos. Este foi o caso, por exemplo, de Crispim da Cunha Tenreiro, genro de Antônio de Mariz. Entre 1587 e 1588, ele ocupa simultaneamente os postos de oficial da câmara e de feitor almoxarife da fazenda real. Anos mais tarde, receberia a serventia do posto de provedor da fazenda real e, já no século XVII, voltaria a ser eleito para o senado da cidade..$^{50}$

\section{Quadro 9:}

\section{Oficiais da câmara, ministros e membros de famílias senhoriais: $1565-1620$.}

\begin{tabular}{l|c|c|c|c|c|c|l}
\hline & of. (a) & min./of.(b) & \% de a & of.- sr. & \% de a & min/of/sr & \% de b \\
\hline $1565-70(5)$ & 17 & 11 & 64.7 & 4 & 23.5 & 4 & 36.4 \\
$1571-80(6)$ & 19 & 11 & 57.9 & 5 & 26.3 & 5 & 45.5 \\
$1581-1600(9)$ & 50 & 30 & 60.0 & 24 & 48.0 & 18 & 60.0 \\
$1601-1620(4)$ & 21 & 10 & 47.6 & 13 & 61.9 & 10 & 100.0 \\
$1565-1620(24)$ & 107 & 62 & 57.9 & 46 & 43.0 & 37 & 60.0 \\
\hline
\end{tabular}

Fontes: Anexo 1; Belchior 1965, 511 e 512; AHU, av, cx. 1, doc. 8; IHGB, t. 88, v. 142, p.396; IHGB, t. 93, v. 147, p. 261; IHGB, t. 95, v. 149, p. 347; RUDGE, R. As Sesmarias de Jacarepaguá, São Paulo, Liv. Ed. Kosmos, 1983, pp. 79 e 101. 
Obs.: 1)of. — oficiais da câmara; min - ministros; sr - famílias senhoriais. 2) Um mesmo oficial pode aparecer em diversas legislaturas/anos. 3) Entre parênteses \# de anos com informação.

O quadro 9 ilustra a possibilidade de um conjunto de conquistadores circularem entre as duas instâncias máximas da governança do Rio de Janeiro: a administração imperial e o senado da câmara. A primeira, nomeada e/ou confirmada por Lisboa, e a segunda, eleita pelo povo (leia-se homens bons) da Conquista. Mas, apesar destas diferenças, ambas com a responsabilidade de gerir os negócios da República. Curiosamente, entre as pessoas que circulavam de um posto para outro da administração pública, encontramos aquelas famílias que, ao longo do Seiscentos, se tornariam donas de engenhos de açúcar.

Dos 107 oficiais do senado que verifiquei para o período 1565 e 1620, 46 , ou $43 \%$, deram origem a famílias senhoriais (ver quadro 9). Mais do que isto, entre estes mesmos 46 oficiais temos 37 que, no período considerado, exerceram postos na administração imperial. Isto significa afirmar que, entre os 62 oficiais da câmara que foram ou ainda eram ministros do rei, mais da metade também seria fundadora de famílias senhoriais. Com isto, começa a se configurar um quadro em que o núcleo da primeira elite senhorial do Rio é gerada por um conjunto de pessoas que são, simultaneamente, conquistadores, homens do rei e representantes do povo. Este é o caso, por exemplo, de Antônio de Mariz e de João de Bastos. Ambos, em tempos diferentes da segunda metade do século XVI, ocuparam o posto de provedor da fazenda real, cargo que lhes dava ascendência sobre os dízimos reais e a alfândega da cidade. $\mathrm{Na}$ mesma época em que exerciam tais funçóes, eles eram eleitos pelos homens bons da cidade para o senado, o que os obrigava a opinar sobre os preços dos gêneros de abastecimento e os fretes da cidade. Não é difícil perceber que tal situação lhes conferia um extraordinário poder na montagem e funcionamento da economia colonial. Fato que é mais reforçado, ainda, quando nos lembramos da delicada teia de relaçôes de parentesco, via casamentos, que desde cedo eles começariam a tecer. Em suma, a combinação de todas estas circunstâncias daria àqueles homens uma posição bastante confortável no mando e, portanto, nos destinos da nova Colônia. 
Entretanto, tenhamos certa cautela em tirar conclusões apressadas. Voltando aos quadros 5 e 9, nota-se que, com o passar do tempo, a capacidade dos funcionários de sua Majestade constituírem famílias originais e, portanto, sem ligações de parentesco pretéritas com antigos domicílios senhoriais, se reduziu razoavelmente. De um total de 40 famílias (extensas e simples) geradas pelos homens do rei até 1700 , somente 15 surgiram após 1621. É desnecessário dizer que depois de 1621 chegariam ao Rio novos ministros, capitães de infantaria etc. Contudo, estes não formariam "linhagens" senhoriais com a mesma facilidade de antes. Ao mesmo tempo, verifica-se nos mesmos quadros que este último período fora a época das famílias senhoriais não oriundas de ministros. Entre 1621 e 1700, temos a formação de 72 famílias originais, das quais 57 , ou $79 \%$, não tiveram como ponto de partida um posto na administração pública. Por conseguinte, neste último período, aparentemente, tais postos perderiam um pouco da sua importância na produção de novas e originais descendências senhoriais, outros mecanismos de acumulação de riqueza, inclusive o comércio, iriam adquirir mais força.

Desta constatação infere-se que um posto da administração da coroa, em si mesmo, não tem o dom de criar domicílios senhoriais. No caso da elite seiscentista do Rio de Janeiro, além dos cargos de sua Majestade, outras circunstâncias também agiriam em sua formação, como por exemplo as próprias possibilidades abertas pela Conquista. ${ }^{51}$ Afinal, uma coisa é ser representante da coroa numa época em que a sociedade colonial está ainda engatinhando, onde a guerra é uma constante e não existem ainda fortes grupos sociais locais constituídos. Outra coisa é ser funcionário em circunstâncias de uma sociedade já estabelecida e, portanto, com grupos sociais e interesses setoriais bem definidos.

No caso do Rio de Janeiro, o que é interessante sublinhar é que os conquistadores/funcionários (suas famílias) conseguiram ultrapassar o período da Conquista e se converteram no núcleo da elite senhorial do Seiscentos, como os quadros 6 a 8 demonstraram e como ainda veremos. Na verdade, no após 1620, os descendentes daqueles funcionários, através do domínio do senado, do sistema de mercês, de estratégia de parentesco e da formação de clientelas, se converteriam naquilo que chamo de "nobreza da República" e com isso dominariam os cenários da sociedade colonial seiscentista. ${ }^{52}$ 
Neste sentido, foi emblemática a trajetória de Ignácio da Silveira Villalobos. Bisneto de um dos primeiros povoadores (família extensa Pontes), se casaria em 1654 com Paula da Costa, filha de Francisco da Costa Barros, bisneta do capitão quinhentista João de Souza Pereira Botafogo e tetraneta de Antônio de Mariz. De seu sogro, Ignácio herdaria a propriedade do ofício de escrivão da fazenda real. ${ }^{53}$ Uma vez viúvo, Ignácio voltaria a se casar, desta vez com Francisca de Araújo de Andrade, ex-mulher de Salvador Correia Vasques, irmão do governador Tomé Correia de Alvarenga (1657-1659) e primo de Salvador Correia de Sá e Benevides. Através destes casamentos, percebe-se a formação de uma vasta e poderosa rede de parentesco formada por três diferentes famílias descendentes de conquistadores. Ao longo de sua vida Ignácio seria dono de um engenho de açúcar e ainda ocuparia, por diversas vezes, um assento no senado da cidade.

Por seu turno, a rede de influência de Ignácio seria ainda mais alargada através do encontro com outros personagens seiscentistas: os Frazão de Souza. Pedro de Souza Pereira, desde pelo menos 1644, possuía o cargo de provedor da fazenda real e de juiz da alfândega. ${ }^{54}$ Pedro, além de senhor de engenho, desde 1648 estava casado com Ana Correia, bisneta de Antônio de Mariz e descendente de Salvador Correia de Sá. Assim sendo, Ignácio e Pedro, através dos Correia e Mariz, participavam do mesmo "círculo de conhecimentos", o que seria ainda mais reforçado com o casamento dos seus "sobrinhos", em 1688, Maria Barbosa e João do Zouro.

Através desta engenharia de alianças e matrimônios teríamos os seguintes resultados práticos: o controle sobre aquilo que chamei de "poupança colonial”, por meio dos ofícios de provedor da fazenda real, de escrivão da fazenda e mais o de juiz de orfãos (propriedade de um dos tios de Ignácio - Diogo Lobo Teles); a proximidade com os governadores da cidade (os Correia); 34 senhores de engenho, no decorrer do século, somando os Pontes, Frazão de Souza e os Correia.

Diante de tudo o que já foi dito, ainda permanece a pergunta: quem pagou a conta da instalação da plantation açucareira, que agora sabemos ter pertencido, em grande parte, aos homens do rei? Para responder a esta pergunta, comecemos por onde tudo começou. 


\section{A conquista, as mercês e a formação de um "mercado imperfeito"}

Alcançada a vitória e curados os feridos, armou Cristóvão de Barros alguns cavaleiros, como fazem na África, por provisōes de el-rei que pera isso tinha, e fez repartição dos cativos e das terras, ficando-lhe de uma coisa e outra muita boa porção, com que fez ali uma grande fazenda de gado, e outros a seu exemplo fizeram o mesmo, com que veio a crescer tanto pela bondade dos pastos que dali se provêm de bois e engenhos da Bahia e Pernambuco e os açougues de carne. ${ }^{55}$

Esta longa passagem é a descrição feita, por frei Vicente de Salvador, dos acontecimentos depois da vitória de Cristóvão de Barros contra os gentios de Cerigipe (Bahia) na passagem de 1590 para 1591. Uma vez vitorioso, o capitão português, a exemplo do que ocorria em outras paragens do Ultramar, "criou” fidalgos e distribuiu as presas de guerra: terras e homens. Com estas terras e homens conquistados, os recém cavaleiros fizeram fazendas de gados. Provavelmente, a mesma seqüência medieval de fenômenos deve ter ocorrido no século XII, em meio à Reconquista cristã, na Península Ibérica, assim como deve ter se repetido no recôncavo do Rio de Janeiro, nas guerras contra os tamoios e franceses nos anos de 1565-67 e em 1575.

$\mathrm{Na}$ segunda metade do século XVI, as pretensões de Lisboa para com a América já eram claras. Antes de mais nada, garantir domínio efetivo das novas terras diante das investidas estrangeiras e das hostilidades dos gentios. Feito isto, em meio à "viragem para o atlântico", o passo seguinte seria viabilizar a economia de plantations aproveitando assim o trend de alta do açúcar. Com esta última medida, pretendia-se, provavelmente, "compensar" o recuo econômico-militar do Estado da Índia, e ainda minimizar as dificuldades financeiras da metrópole. Daí se entende a construção, pelo governador Antônio Salema (1576-77), de um engenho de açúcar às custas da fazenda real no Rio de Janeiro, ${ }^{56}$ ou ainda a possibilidade dada pelo rei ao governador do Maranhão de receber a propriedade do ofício de provedor da fazenda, contanto que ele construísse no prazo de seis anos dois engenhos de açúcar (Frei Vicente Salvador 1982, 355). Entretanto, só projetos não bastavam. Para a montagem, não de um ou dois engenhos, mas 
de uma economia de plantations, seriam necessários recursos. Algo que, como já vimos, andava escasso em Portugal. Neste sentido, a química da conquista começa a adquirir um novo significado. Isto é, ela surge como a possibilidade de montagem da economia exportadora. Aquela química fornecerá, a baixos custos, os dois elementos fundamentais para a instalação da nova estrutura produtiva: terras e mão de obra.

Não é inteiramente sem motivo que tanto no regimento de Tomé de Souza (1548), como no “instrumento dos serviços” de Mem de Sá (1570), ambos Governadores do Brasil, a guerra e domínio dos indígenas ocupem a maior parte das preocupações listadas por Lisboa. E daí não ser surpresa que, em Pernambuco, entre 1570 e 1583 , cerca de 2/3 da população escrava dos engenhos de açúcar fosse formada por índios. ${ }^{57}$ Voltando para o Rio quinhentista, somente na expedição punitiva comandada por Antônio Salema, que contou com o mesmo Cristóvão de Barros, contra os tamoios de Cabo Frio em 1575, foram capturados 4.000 prisioneiros convertidos em escravos. Da mesma forma, não é de se estranhar que, ainda na terceira década do século XVII, na correspondência mantida entre o governador do Rio de Janeiro Martim de Sá e Lisboa, se encontre passagens como "a gente do Brasil não pode fazer suas fazendas senão com estes indios que são todo o seu remédio". Na mesma época, em uma carta anônima do Rio, pede-se armas e panos para o combate de inimigos e "sobretudo para o resgate do gentio". 58

Como conquistadores, os companheiros de Mem de Sá e Antônio Salema receberiam as maiores sesmarias de terras. Segundo Teixeira da Silva, a distribuição de sesmarias no Rio não foi presidida pela pressão demográfica. Na verdade, a malha fundiária inicial da capitania parece ter acontecido independentemente do crescimento demográfico. Uma das razões para isto foi a intenção do Estado de pagar, com terras, a burocracia que procurava instalar na Colônia. Entre as conseqüências de tal medida, teríamos uma primeira estrutura fundiária caracterizada pela concentração de terras em poucas mãos. ${ }^{59}$

Entretanto, na montagem de uma economia de plantations não basta apenas terras e mão-de-obra. Além do que, nem todos os cativos das primeiras gerações de senhores eram índios. Com o avanço do século, uma parte cada vez maior de tais planteis seria constituído por africanos e, por- 
tanto, comprados ao tráfico atlântico de escravos, o que significa a necessidade de recursos monetários. Por seu turno, a tomada do recôncavo do Rio de Janeiro não só facultaria a seus conquistadores terras e índios, mas também mercês na forma de privilégios no comércio, e ainda de postos na administração pública com as suas respectivas remunerações.

O sistema de mercês tem as suas origens nas guerras de Reconquista contra os muçulmanos na Península Ibérica da Baixa Idade Média. Em meio a estas guerras, o rei luso concede, principalmente à aristocracia, terras e privilégios (arrecadação dos direitos régios) como recompensa de serviços prestados. ${ }^{60}$ Uma das conseqüências de tais práticas seria a formação, em Portugal, de uma aristocracia não tanto constituída por grandes proprietários, como ocorre na Inglaterra e França, mas sim, principalmente, por beneficiários dos favores do rei; ou melhor, por aqueles cujas rendas dependiam dos dízimos, dos direitos de foral e dos foros enfitêuticos; rendimentos, em grande parte, sujeitos à confirmação régia. Entre 1750 e 1792, por exemplo, 30 das 52 casas da alta nobreza do país tinham mais de 50\% dos seus rendimentos retirados dos bens concedidos pela Coroa. Através deste sistema, a Coroa criava e recriava uma hierarquia social fortemente desigual, baseada em privilégios, ou, o que é o mesmo, dava vida para uma sociedade aristocrática. ${ }^{61}$

A partir de 1415, com a tomada de Ceuta, aquelas práticas tenderiam a ser transmitidas para o ultramar. Nas Conquistas, a Coroa concedia postos administrativos ou militares (governador, provedor da fazenda etc.) que podiam proporcionar, além dos vencimentos, privilégios mercantis, viagens marítimas em regime de exclusividade ou isenção de taxas e direitos alfandegários. Por exemplo, na Ásia, existiam as "liberdades da Índia”, ou seja, o direito de transportar gratuitamente, nas embarcaçóes da Coroa, as mercadorias privadas. ${ }^{62}$ Já em Angola, o governador Henrique Jacques Magalhães, em 1695, solicitava o mesmo privilégio já usufruído por seus antecessores — o de retirar sem ônus 600 "cabeças" (escravos) e, mais, navegar marfim sem o constrangimento dos contratadores. ${ }^{63}$ Tais mercês eram concedidas conforme a química de dois critérios: a posição social do postulante ao benefício e a importância dos serviços prestados. 
Para os de origem nobre, os benefícios concedidos no além-mar eram a chance de manter/ampliar terras, rendas e prestígio na metrópole. Através destas idas ao ultramar, famílias fidalgas acumulavam fortunas com as quais instituíam ou aumentavam morgados. São exemplos deste fenômeno os Albuquerque e Saldanha, que estiveram à frente, respectivamente, do governo da Índia e Angola/Rio de Janeiro, ou ainda o caso de Duarte Sodré Pereira, antigo governador de Pernambuco. Não é difícil perceber que tais movimentos ajudam a explicar a preservação da estrutura social aristocrática em Portugal. ${ }^{64}$

Por seu turno, a prática de concessão de postos no ultramar não era um privilégio apenas concedido aos extratos da aristocracia, pois ela também se estendia a outros mortais. Antigos soldados ou pessoas de origem social não-nobre também podiam receber cargos e ofícios nas Conquistas como forma de remuneração de seus préstimos ao rei. E, da mesma maneira que os fidalgos, aqueles também tinham em tais funções a possibilidade de enriquecerem.

Conforme Boxer narra, caso tivesse sobrevivido às campanhas militares e misérias do Oriente, um soldado depois de servir alguns anos pedia ao rei, por intermédio do governo vice-real de Goa, pensões ou recompensas. Uma vez que a coroa decidia que o solicitante era digno de recompensa, que, em geral, assumia a forma de doação de um cargo (capitão-de-fortaleza, escrivão da fazenda real etc.), de uma concessão de viagem comercial, ou ainda de um posto de agente em uma obscura feitoria. Na maioria dos casos, estas doações revestiam a condição de serventia por três anos e, por serem freqüentes, muitas vezes geravam situações em que seus pretendentes deviam esperar por décadas até ocuparem o posto pretendido. Em determinadas circunstâncias, tais benefícios reais podiam ser doados e mesmo vendidos a terceiros. ${ }^{65}$

Em 1607, discutiu-se em Lisboa quais seriam os meios para sanear as finanças públicas e uma das soluções cogitadas foi a venda dos ofícios de escrivães do judicial, da almotaçaria, das ordenanças e de tabeliães de notas. Nas primeiras décadas do século XVII, e também para resolver problemas de caixa, vários cargos públicos no Estado da Índia seriam postos à venda, fato que geraria forte descontentamento entre os soldados que ser- 
viam nesta parte do império português. ${ }^{66}$ Apesar de prevista nas Ordenaçôes do Reino, a venda de cargos feitas por Lisboa, pelo menos no Rio de Janeiro quinhentista e seiscentista, parece não ter tomado as mesmas proporções que na América espanhola. Madri, desde meados do século XVI, começaria a abandonar o sistema de mercês e a adotar a prática de negociar os postos da administração municipal e, a partir de 1633, o mesmo ocorreria com os postos da fazenda. ${ }^{67}$

Uma das primeiras formas de benefício solicitada pelos conquistadores e seus descendentes, no Rio de Janeiro, diz respeito às presas de guerras. Nesta condição, além das terras e do gentio, temos as fazendas capturadas dos inimigos europeus. Em 1616, Martim de Sá, alegando os baixos salários de capitão da cidade e o grande ônus de andar sempre embarcado para vigiar as costas do sul, solicita ao rei parte das mercadorias tomadas nas naus dos inimigos e para isto pede, ainda, que os oficiais da fazenda não interferissem em tais naus. ${ }^{68}$

Por sua vez, a exemplo do que acontecia em outras paragens do império português, no Rio de Janeiro seriam concedidas mercês que afetavam diretamente o comércio da economia da Conquista. Em 1653, Salvador Correia de Sá e Benevides envia ao Conselho Ultramarino uma carta onde escreve que

elle tem no reconcavo daquela cidade cinco engenhos de fazer açúcar, quarenta curraes de gado, casas e foros que se lhe pagam, que é a renda com que se sustenta neste reino (...) e não será justo que sendo ele Alcaide-mor daquela cidade e a pessoa que mais fazendas tem nella, lhe falte donde carregar os ditos açucares (...) Pede a vmagestade lhe faça merce mandar passar provisão para que todos os navios que navegarem no Rio de Janeiro, lhe tragam dez porcento do que poderem trazer neles, pelo frete ordinário que trouxerem aos mais ministros. [grifos, JF]. ${ }^{69}$

O contexto desta carta é o do sistema de frotas que, instituído desde 1644, determinava que toda navegação do Brasil para Portugal deveria ser feita em comboios dirigidos pela coroa. ${ }^{70}$ Apesar de garantir uma maior segurança para o transporte do açúcar numa época de conflitos - em particular contra os holandeses — tal sistema teria forte resistência dos coloniais, entre outras razões, pela falta de navios para o transporte da produ- 
ção colonial. ${ }^{71}$ Por conseguinte, a concessão da mercê solicitada por Salvador significava um nítido desequilíbrio entre os senhores de engenho. Com tal benefício, fica claro que nem todos os produtores de açúcar eram iguais diante do mercado e, com isto, Salvador, "a pessoa que mais fazendas tem", destaca-se ainda mais entre os "afazendados" da Colônia.

Anos mais tarde, o mesmo Salvador, alegando novamente os serviços prestados por sua família ao rei, voltaria a solicitar mais privilégios à Lisboa. Desta vez, o objeto do pedido foi o mercado de carnes. Diante da existência de vários pecuaristas e da obrigação de abaterem seus rebanhos apenas no açougue público, Salvador solicita a mercê para que, diariamente, 6 a 8 reses de seus currais fossem abatidas. ${ }^{72}$ Mais uma vez ele seria agraciado por sua Majestade.

Através destes exemplos do Rio, percebe-se que uma das conseqüências da transmissão do sistema de mercês para o ultramar seria a constituição de um mercado "imperfeito". Ou seja, de um mercado não totalmente regulado pela oferta e procura, e onde a ação dos agentes não dependia apenas de seus recursos econômicos. Uma pessoa que tinha o posto de governador de Angola, e com isto a possibilidade de retirar de Luanda escravos sem pagar impostos, evidentemente possuía maiores condições de auferir lucros do que um simples traficante. O mesmo ocorria com os Capitães de Malaca que, com seus monopólios comerciais concedidos pelo Estado, possuíam maiores vantagens do que os demais mortais. Nestes casos e em outros, portanto, nota-se a constituição de mecanismos de acumulação que, mesmo realizados no mercado, são mediados pela política. E isto fica mais claro quando lembramos que a concessão de mercês e, portanto, a possibilidade de adquirir vantagens no comércio, obedecia também a critérios sociais. Um fidalgo tinha mais chances de receber o posto de capitão de Malaca, por exemplo, do que um antigo soldado oriundo do braço popular. Cabe ainda sublinhar que o sistema de privilégios, uma vez que estabelecia capacidades diferenciadas de acumulação entre os negociantes, inevitavelmente imprimia tonalidades especiais às cores do mercado do além-mar. Tonalidades estas desenhadas a partir da política e, por conseguinte, de fora para dentro do mercado. Enfim, tal fenômeno retirava do mercado parte de sua capacidade de se auto-regular, já que esta regulação 
em parte era feita por relaçôes sociais estranhas à economia mercantil, mas compatíveis com a economia política do Antigo Regime português. ${ }^{73}$

Retornando ao Rio de Janeiro seiscentista, deve-se destacar que aqui os efeitos do sistema de "benefícios" sobre a economia e sociedade coloniais seriam, em tese, mais duradouros. Ao contrário de outras partes do ultramar, na cidade de São Sebastião, as fortunas constituídas através das mercês não necessariamente eram transferidas para Portugal e convertidas em morgados. Aqui o que se nota, também, é que tal prática de acumulação servia de meio para a montagem de patrimônios escravistas, inclusive, na forma de engenhos. Ao mesmo tempo, verifica-se que no Rio de Janeiro, a constituição de um "mercado imperfeito" não só será o resultado do tipo de mercês acima visto, mas também da remuneração regular dada aos ministros e oficiais da administração.

Infelizmente, para os primeiros beneficiados com postos administrativos, no Rio de Janeiro, pouco sei. Ou melhor, além de serem os conquistadores do recôncavo, e por isto terem recebidos cargos administrativos e militares que lhes davam a chance de montar e comandar a sociedade colonial local no século XVI, disponho de poucas informações sobre o tempo de duração e a natureza da remuneração de tais mercês. Em vista disto, parti do pressuposto que os ofícios seriam dados, principalmente, em serventia por três anos. Sendo isto verdade, tal caráter temporário dos postos podia e foi perfeitamente contrabalançado, na época estudada, pelas possibilidades de uma mesma pessoa, ao longo de sua vida, ocupar diversos cargos e com isto não sair da administração da coroa. Além disto, como também já vimos, as estratégias de casamento fariam com que alguns conquistadores e parentes, de uma maneira direta ou indireta, sempre estivessem presentes na administração da coisa pública.

Passando para meados do Seiscentos disponho de um maior número de cartas de patentes e de provisóes, o que me permite informaçóes mais seguras. Alguns dos ofícios não recebiam ordenados, e deste modo, não representavam despesas para a fazenda real. Esta era a situação dos ofícios da ouvidoria e da correição (com exceção do ouvidor) e também do juízo de órfãos. A renda de tais oficiais era em emolumentos e o seu pagamento feito pelo "público" a quem servia. O rendimento de um escrivão de notas dependia, por exemplo, das escrituraçôes e diligências que faziam. 
Enquanto isso, existiam ofícios, como os da fazenda real, cuja renda era composta por três rubricas: ordenados, emolumentos e propinas retiradas da arrematação dos contratos de impostos. Entre 1640 e 1697 o ordenado destes ministros e oficiais, ou aquilo que o rei lhes pagava, permaneceria praticamente congelado. Para 1697, ano em que é possível se ter uma idéia do peso de cada uma daquelas rubricas no rendimento total para o conjunto dos oficiais da fazenda, observa-se que os ordenados correspondiam a apenas 9,1\%. Em contrapartida, os emolumentos e vistorias dos navios respondiam por $78,6 \%$ da renda total $(2: 021 \$ 200)$ destes funcionários. ${ }^{74}$ Em outras palavras, sua Majestade arcava com a menor parte da remuneração de seus funcionários da fazenda, e estes eram pagos principalmente pelo comércio e os arrematantes de impostos. Neste momento, caberia indagar o significado de tais fenômenos para os ministros e oficiais.

Ao longo dos mais de cinqüenta anos considerados, o escrivão da fazenda real e da matrícula de guerra recebe o salário “congelado" de $17 \$ 400$. Com esta quantia, segundo os preços de 1697, ele teria que esperar por quase cinco anos para comprar um escravo homem com cerca de 25 anos, no valor de $85 \$ 000$. Em situação um pouco melhor estaria o provedor da fazenda que com os ordenados de pouco mais de um ano poderia adquirir o mesmo cativo. Entretanto, este quadro se modifica por completo quando consideramos, além daqueles vencimentos, o que eles recebiam com os emolumentos retirados da alfândega e das propinas. Somando todas estas parcelas temos que a remuneração do provedor da fazenda, por exemplo, chega a $800 \$ 000$. Quantia que lhe permitiria, em uma ano, adquirir um plantel de quase 10 cativos ou comprar, depois de três anos, a metade do engenho de Francisco Ferreira Drumond, vendido em 1697, com 12 escravos, 73 bovinos, duas moendas etc., pelo preço de 2:400\$000. ${ }^{75}$ Feito isto, o nosso provedor poderia pensar seriamente em entrar no restrito clube dos senhores de engenho que, em finais do século XVII, contava com um número de sócios correspondente aos proprietários dos 130 engenhos existentes na capitania.

Em suma, nota-se que frente aos baixos e "congelados" ordenados contrapõem-se os emolumentos e as propinas. Rubricas que, por estarem ligadas ao desempenho anual da produção social, no caso dos oficiais da fa- 
zenda, dependia do movimento dos navios no porto e da arrematação dos dízimos. Fenômeno que transformava tais postos em objetos de disputas não tanto em razão dos ordenados pagos pelo Estado, mas sim em função do que sua Majestade lhes permitia retirar do "público" ou, o que é o mesmo, diretamente da riqueza social. Partindo da experiência do Rio de Janeiro seiscentista, aquilo que era retirado do público dependia de circunstâncias não necessariamente regulamentadas pela lei, mas sim por outras variáveis, políticas e sociais. Vejamos isto mais devagar.

A natureza emolumentar de parte das receitas dos oficiais e ministros era uma prática vinda do Reino ${ }^{76} \mathrm{e}$, portanto, presente no Rio desde "priscas épocas". Neste sentido, não é de estranhar que em uma carta enviada pelo senado da câmara à Lisboa, em 1643, fale-se em "costumes antigos" do provedor e demais oficiais da fazenda em "cobrar percalços sobre as entradas e saídas das embarcações” do porto. Nas circunstâncias coloniais, estes costumes antigos assumiam um significado mais preciso quando se lê mais adiante, na mesma carta, "não haver na alfândega da dita capitania regimento que se limitasse o que se deve levar dos despachos, entradas, e saidas das embarcaçôes" ${ }^{77}$ Isto é, até 1643, não existiam na fazenda real normas claras quanto aos limites dos emolumentos que os seus oficiais poderiam cobrar sobre o comércio marítimo da cidade.

Ao que parece, algo semelhante também ocorria em outro setor estratégico da "riqueza colonial", no caso, na remuneração dos serviços do juizado de órfãos. Numa correspondência da câmara para o rei, datada de 1651, eram denunciados vários abusos do juiz e escrivães de órfãos, entre eles o de cobrar taxas diárias excessivas para a feitura de inventários post mortem cujos bens estivessem fora da cidade. A mesma carta lembra que no Rio de Janeiro da época, por ser uma região fundamentalmente rural, a maior parte de seus bens se encontravam distantes do centro urbano. ${ }^{78} \mathrm{O}$ fato dos juizes de órfãos poderem cobrar taxas abusivas sugere que, até aquela data, não existia no juizado normas que regulassem claramente os seus emolumentos. A presença do mesmo fenômeno, tanto na fazenda real como no juizado, adquire aspectos especiais quando lembramos algumas coisas:

1- O Rio de Janeiro, no período considerado, estava vivendo a montagem e expansão de uma economia exportadora. Portanto, o porto era uma 
de suas principais artérias de circulação de mercadorias, por ele passando parte expressiva de todas as vendas e compras desta economia. Quanto aos inventários, por eles transitava a própria riqueza social. Assim sendo, pelo porto e o juizado passaria, se não toda, parte significativa do total da riqueza produzida e acumulada na Colônia, e é sobre ela que incidiriam os rendimentos e emolumentos dos ministros.

2- Diante do público (comércio e lavoura), os titulares da provedoria da fazenda, do juizado de órfãos e de outros postos administrativos eram a própria autoridade colonial, portanto, a quem se devia obedecer.

A inexistência de regimentos, que legislassem rigorosamente os emolumentos, transferia para a elite político-administrativa a possibilidade de regular a principal fatia de seus próprios rendimentos. Na verdade, tal regulação passaria a depender das negociações entre tal elite e a sociedade colonial em gestação, ou melhor, passa a depender das alianças políticas que eles conseguem tecer na sociedade.

A partir destas informações não há por que se espantar com o tom de lamúria contida na carta de 1643: "até o ano de 1628 levaram os provedores da fazenda direitos e percalços moderados (...) de despacho de hum navio 4 mil réis e de hum barco 1 pataca. Ede 1628 até hoje levam por o dito despacho 16 a 20 mil reis e de hum barco da costa 12 e 14 patacas". 79 Em que pese o possível subregistro de tais números para antes de 1628, ou o seu exagero para depois, eles indicam a possibilidade dos provedores e outros oficiais da fazenda se apropriarem de parte da riqueza social. E, mais uma vez, o mesmo pode ser dito para os titulares do juizado de órfãos. Para tanto basta lembrar que, segundo a carta-denúncia de 1651, neste ano um dia de trabalho de um juiz de órfãos fora da cidade custava $4 \$ 000$ e de seu escrivão $3 \$ 000$. Com a primeira quantia, se correta, um juiz, ao fim de vinte dias de serviços no campo, poderia comprar um escravo com a qualificação profissional de oleiro que, na época, custava $80 \$ 000$.

Entretanto, o quadro ainda não está completo. Além dos governadores, ouvidores e provedores, outros serviços à República eram também pagos em emolumentos, prós e percalços. Este era o caso dos capitães-de-fortaleza e os tabeliães. Em 1636, Antônio de Faria recebia a mercê do cargo de capitão-da-fortaleza de Santa Cruz, um dos dois fortes situados na entrada 
da baía de Guanabara. Na sua carta patente pode-se ler que ele gozaria, além do ordenado, de "todos os proes, e percalços, que lhe pertencerem [ao cargo], e levaram vossos antecessores". Entre os seus antecessores encontramos Gonçalo Correia de Sá, e antes dele Pedro Gago da Câmara. O primeiro, era irmão de Martim de Sá e, desde 1610, possuía um engenho de açúcar. O segundo teria uma passagem pela câmara municipal em 1614 e entre os seus filhos há um senhor de moendas, e um casamento na família Pontes (juizado de órfãos e fazenda real), fenômeno que voltaria a se repetir mais duas vezes com os seus netos. ${ }^{80}$

Quanto à outra fortaleza da barra, a de São João, até 1634, pela sua capitania passariam Duarte Correia Vasqueanes, e antes João Gomes da Silva. Duarte era senhor de engenho, tio de Martim de Sá e, em 1632-33, serviria interinamente no posto de governador. ${ }^{81}$ Quanto a João, era genro de Diogo de Mariz com quem tinha, desde 1610, uma fábrica de açúcar, e como seu sogro fora provedor da fazenda, a exemplo de Pedro Gago da Câmara, em 1614 ocupara um lugar no senado.

Percebe-se, portanto, que entre os responsáveis pela primeira linha de defesa do recôncavo repete-se, no período considerado, o padrão antes visto para outros ministros e oficiais, qual seja, laços de parentesco com famílias da administração imperial e assento no senado. Na verdade, parece que em determinados momentos, os postos de governador, da provedoria da fazenda, de juizado de órfãos, e agora os da capitania de algumas fortalezas, circularam entre pessoas, direta ou indiretamente, aparentadas.

As possibilidades de ganhos materiais com tais capitanias são "insinuadas" através do cruzamento de algumas cartas patentes, com as biografias de seus capitães. João Rodrigues Bravo, em 1635, recebia por cinco anos a fortaleza de S. Bento, cuja construção fora feita "as suas custas". Apesar de tais gastos em sua fazenda, sublinha a carta real que ele não receberá ordenado, podendo entretanto, retirar emolumentos deste seu ofício. Coincidentemente, João era comerciante, e em 1637 arremataria os dízimos reais da capitania. ${ }^{82}$ Décadas mais tarde, a mesma coincidência voltaria a se repetir com outros capitães de fortaleza. Ignácio Francisco de Araújo, em 1698, é capitão da fortaleza de S. Sebastião, e na mesma época, aparece como um dos implicados nas irregularidades do contrato das Baleias. 
Ignácio, por casamento, estava ligado a uma das mais tradicionais famílias de comerciantes e dizimeiros da cidade. Entre os parentes de sua mulher temos os contratadores dos dízimos de 1686 e de $1698 .^{83}$

Esta coincidência entre capitania de fortalezas e comércio talvez possa ser esclarecida por Diogo Couto, cronista do Oriente português do século XVI. Segundo ele, nos soldados da Índia é corrente a "mecânica e vil subtileza de adquirir dinheiro", sendo os capitães das fortalezas tanto mercadores como militares. ${ }^{84}$ Não seria de espantar que o mesmo ocorresse no Rio de Janeiro.

Por conseguinte, o que chamei antes de "mercado imperfeito" não decorreria apenas dos benefícios reais concedidos a uma ou outra pessoa sobre um determinado setor do comércio. O predomínio dos emolumentos nos rendimentos dos ministros/oficiais e ainda, provavelmente, os prós e percalços das capitanias teriam o mesmo efeito, qual seja, diferentes e melhores oportunidades destes ministros e capitães, diante dos demais mortais, na formação das fortunas coloniais. Sendo que aqui impõe-se um novo condicionante. Ao contrário de outras mercês, o quantum dos percalços não era, necessariamente, regulamentado ou somente fixado por sua Majestade, mas também dependia das relaçōes políticas e de parentela presentes na própria Conquista. Por outro lado, os mesmos fenômenos que atuavam na maior flexibilidade dos emolumentos, podiam servir também como pano de fundo para outras "práticas" dos ministros e oficiais em relação aos assuntos da república.

Em princípios do século XVII, os jesuítas acusavam os capitães seculares do Rio de possuírem imensas escravarias formadas pelo gentio da terra. Entre os principais acusados temos Salvador Correia de Sá e Tomé de Alvarenga, respectivamente, antigo governador e ouvidor da cidade. Além disso eram aparentados, através do casamento do irmão de Salvador, Manuel Correia, com uma das filhas de Tomé. Tempos depois, o governador da cidade, em 1645, Francisco Soutomaior, relatava o desaparecimento de um aldeamento de índios formado, provavelmente nos anos de 1610, pelo então governador Martim de Sá, mas às custas da fazenda real. A razão para este desaparecimento teria sido a transferência de tais índios para as "fazendas e engenhos do dito Martim de Sá". Curiosamente, Martim exercera o 
posto de "administrador geral dos índios e aldeias destas costas" na mesma época. ${ }^{85}$

Ainda nas primeiras décadas, pode-se ler na correspondência para Lisboa, denúncias de "roubos que por estas partes se fazem a Real Fazenda". Em 1619, o governador Constantino Menelau e o capitão de Cabo Frio Estevão Gomes foram acusados de negócios ilícitos com o pau-brasil e de desvios do almoxarifado real. Como resultado de tais atividades, Constantino "deixou comprado um engenho para se agasalhar". ${ }^{86}$ Quanto a Estevão Gomes, coincidentemente, já em 1610, tinha comprado um engenho de açúcar.

Depois das denúncias contra os governadores, nenhum outro posto foi alvo de tantas críticas como o dos ocupantes da provedoria da fazenda. De 1639 a 1687, este cargo fora ocupado, com alguns intervalos, pela família Frazão de Souza ou, mais precisamente, por um pai e seus dois filhos, Pedro de Souza Pereira, Tomé de Souza Correia e Pedro de Souza Correia. Ao longo destes 48 anos, as denúncias contra progenitor e rebentos se repetem quase que de uma maneira monótona. Eles foram acusados da cobrança de direitos excessivos sobre o comércio marítimo, de ação ilícita na arrematação dos dízimos reais, de fraudes no contrato do imposto da baleia, de mandos e desmandos na cidade. Na revolta de 1660-61, Pedro, o pai, seria preso pelos rebelados e contra ele foram arrolados 40 capítulos denunciando o seu comportamento frente à provedoria. Segundo tais capítulos, de 1645 a 1660, o provedor teria subtraído parte dos rendimentos dos dízimos reais. Mais de quinze anos depois, o governador da cidade, Mathias da Cunha, acusaria Tomé de Souza Correia de ter arrematado o contrato das baleias através de um de seus criados, o que era proibido por lei, já que cabia ao provedor da fazenda real conduzir a arrematação dos impostos. No mesmo ano, um estudo feito no Conselho Ultramarino concluía que a fazenda real do Rio tinha poucos ganhos com o contrato das baleias. Uma das razões para isto seria o aluguel pago pelo uso da fábrica das baleias, cuja propriedade pertencia à família Frazão. Um dos proprietários de tal fábrica era Pedro de Souza Correia. ${ }^{87}$

Mas não só os Frazão de Souza foram denunciados por corrupção. No final do século XVII, ocorria uma denúncia de irregularidade no contrato 
das baleias envolvendo outras melhores familias da terra. Numa carta enviada a Lisboa no ano de 1696, o governador da cidade, Sebastiāo de Castro e Caldas, acusou o provedor da fazenda real, Francisco de Brito Meireles, e o escrivão da fazenda, o senhor de engenho Inácio da Silveira Villalobos, de terem favorecido o também dono de moendas, Manuel Correia de Araújo, na arrematação daquele contrato. Francisco e Inácio seriam, respectivamente, sogro e padrasto de Manuel que, por sua vez, descendia de antigos governadores da cidade, como Tomé Correia de Alvarenga e Salvador Correia de Sá e Benevides. Ao fazer tal acusação Sebastião Caldas temia sofrer represálias pois, segundo ele, os denunciados eram poderosos para se ter como inimigos e "cada hum deles [Francisco e Inácio] tem mais de 100 mil cruzados e são dos principais e mais aparentados nesta terra" ${ }^{8}$

Por último, um dos melhores resumos das oportunidades de acumulação de riquezas que os cargos da administração da coroa poderiam encerrar é encontrado numa correspondência enviada, em 1669, pela câmara do Rio de Janeiro à Lisboa. Neste ano, o Frei Mauro da Assunção, Abade do Mosteiro de S. Bento, como procurador da cidade do Rio de Janeiro, enviou à Lisboa uma carta

apontando ao rei as causas da ruina daquela cidade e os remédios que lhe pareciam convenientes. Para este procurador, "os augúrios da Conquista não estariam identificados com a perda do comércio com Buenos Aires [o que implicou no fim do acesso à prata de Potosi] e nem com as más colheitas, mas sim com o comportamento dos oficiais e ministros daquele povo". [Estes estariam] roubando os vassalos de V.A. fazendo estanque dos gêneros os quais lhes vendem como refinados mercadores por preços tão excessivos e exorbitantes.

Ao mesmo tempo, para que a situação do Rio de Janeiro melhorasse, seriam necessárias algumas medidas, e entre elas:

que os ministros se não aproveitem do dinheiro do donativo que ha e poderá haver ou que por qualquer outra via pertença a V.A. (...) que tais ministros se não aproveitem dos seus cargos, do dinheiro do juizo de órfãos, e da Provedoria dos defuntos e ausentes; que [os ministros] não comprem dividas a huns moradores para cobrar de outros; que não mandem lançar aos leilôes por seus criados e arrematar bens dos moradores por pessoas de sua casa; que não mandem cobrar as suas dividas, ou as alheias extrajudicialmente por ajudantes e sargentos... etc. ${ }^{89}$ 
Assim sendo, o poder de tais cargos poderia permitir exercício das seguintes práticas:

1- Monopólios no mercado. Cabe lembrar, mais uma vez, que desde os anos de 1640, todo o comércio com Portugal era feito pelo sistema de frotas, sendo isto supervisionado pelos ministros. É neste contexto, previamente monopolizado pelas medidas metropolitanas, que os ministros encontravam o ambiente ótimo para atuarem como "refinados mercadores".

2- Usura. Em um mercado inconstante como o colonial, caracterizado por bruscas flutuações de preços e colheitas, por especulações e pela falta de liquidez, era comum o endividamento e a arrematação de bens por dívidas. Nestas circunstâncias, os ministros, valendo-se de seus postos, negociavam com tais dívidas e arrematações.

3- Apropriação da "poupança" colonial. Como já vimos, parte das fortunas do público colonial era depositada na arca dos órfãos, uma outra parte ia para a guarda da provedoria dos defuntos e ausentes, ou ainda era transferida para os cofres públicos na condição de impostos; neste último caso, temos os donativos feitos ao rei. Por conseguinte, tal arca, provedoria e cofre, na prática, teriam o papel de caixas econômicas que concentravam parte da riqueza produzida pela sociedade. Em um ambiente pré-industrial, como o colonial, onde prevaleciam as dificuldades de crédito, os ministros teriam acesso privilegiado a tal caixa, ou melhor, tomariam "empréstimos" desta poupança colonial.

Em suma, segundo o quadro desenhado pelo frei Mauro, a economia de plantations do Rio de Janeiro seiscentista configuraria um cenário de "mercado imperfeito", onde as oportunidades econômicas dos coloniais eram nitidamente diferenciadas. Estas diferentes oportunidades não seriam resultado do monopólio de alguns sobre os meios de produção, mas sim do acesso aos cargos de mando da administração de sua Majestade. Na verdade, teríamos processos de enriquecimentos feitos no mercado (monopólios de mercadorias, usura etc.) ou não, mas mediados pela política. Com isto se configura uma espécie de acumulação excludente, onde a elite que detém o controle da coisa pública exclui os demais mortais: o público.

Entretanto, isto não significa que o cargo de ministro tivesse em si algum atributo mágico que lhe conferisse autoridade absoluta e sem limi- 
tes sobre a sociedade. Pelo menos, não é isto o que sugerem algumas passagens da vida de certos governadores, ou seja, do principal ministro do rei na cidade. Neste sentido, basta lembrar os temores do governador Sebastião de Castro e Caldas ao denunciar dois de seus subordinados, o provedor e o escrivão da fazenda, por pertencerem às famílias principais e mais aparentadas da terra. Da mesma forma, os limites do poder dos ministros pode ser percebido nos relatos do governador Francisco Soutomaior quando desembarca no Rio em 1645. Por esta época, segundo o governador, o cenário da cidade seria dominado por "bandos", "tão bárbaro e tão inculta nas materias de milicia, fazenda e justiça”. Para concluir, Francisco afirma que só pudera assumir o seu cargo por ter em sua companhia mais de cem mosqueteiros. ${ }^{90}$

De fato, os ministros só exerciam plenamente aquilo que chamei de acumulação excludente quando, além das prerrogativas de seus postos, eram aparentados na terra ou, que é o mesmo, estavam próximos a um dos bandos da cidade. Muitos dos ministros e oficiais eram descendentes dos conquistadores e pertenciam às melhores familias da terra, ou melhor, a uma nobreza da República.

Pela cronologia dos exemplos acima, percebe-se que a interferência da política (sistema de mercês e alianças) sobre a economia, ultrapassa os tempos da conquista e mesmo aquele período (até 1620) que considerei como chave na montagem da economia de plantations e de sua elite. Mesmo após esta época a economia colonial continuaria sendo feita em condiçôes de "mercado imperfeito" ou de "antigo regime", onde privilégios formados na política condicionariam as taxas de acumulação de riquezas. Fenômeno que traria para o centro dos mecanismos de reprodução da economia colonial seiscentista o controle sobre os postos da administração colonial e, conseqüentemente, as alianças políticas. Destes fenômenos decorreriam possibilidades maiores de hegemonia e enriquecimento. É desnecessário dizer que tais características, por sua vez, geravam contínuos conflitos dentro da elite senhorial. Um destes palcos era o senado da câmara.

\section{Senado da Câmara e a economia da República}

O senado, segundo os seus camaristas em 1678, era "a cabeça da República para o bem comum”. Como tal, e a exemplo do que ocorria na Eu- 
ropa pré-industrial, cabia a esta assembléia interferir em setores vitais da economia da República, como o abastecimento da cidade e mesmo a administração de certos impostos. ${ }^{91}$

Entre as práticas mais constantes da câmara, temos o estabelecimento de preços máximos para os gêneros alimentícios considerados essenciais. Em 1642, "na dita Câmara acordaram os ditos oficiais que (...) a carne se venda de hoje em diante a vinte o arretel". Dois anos depois, algo semelhante ocorreria com a farinha. Esta não poderia ser vendida "por mais preço que por doze vinteis com pena que quê a vender por mais ser preso". Caberia perguntar quem eram estes homens que determinavam os preços e que, com isso, interferiam no funcionamento do mercado colonial. ${ }^{22}$

No quadro 10, apresento todos os vereadores, juizes ordinários e procuradores que conheço entre 1567 e 1700. Dos 449 oficiais arrolados para o período, nota-se que pouco mais de $2 / 3$ deram origem ou pertenciam a famílias senhoriais. Por conseguinte, os senhores de engenho tinham a capacidade de interferir em um item fundamental na montagem e custeio de suas fábricas e escravarias, qual seja, o preço dos produtos que formavam a cesta básica de seus cativos e empregados. Mais do que isto, observase que, daqueles $449,38,7 \%$ eram conquistadores ou seus descendentes e ainda que, dos 289 oficiais da elite senhorial, 60,2\% vinham do período da Conquista. Assim sendo, percebe-se que, ao longo de quase 150 anos, os conquistadores e seus rebentos controlaram a "cabeça da República para o bem comum", o que, sem dúvida, deve ter facilitado a constituição e a manutenção de seus engenhos. Neste sentido, vale lembrar que famílias como os Mariz ou os Castilho Pinto, mesmo antes de se tornarem donas de moendas, já tinham assentos no senado. ${ }^{93}$

Por estes números, não era de estranhar que os membros do senado da câmara se intitulassem, a exemplo do que ocorria em Portugal, a nobreza da terra e da governança. Da mesma maneira, não é de surpreender que, numa provisão lida em plenário, no ano de 1640, se determine "que nomeem para almocateis senão pessoas das mais nobres da terra e do governo della e que não fossem nem eles nem seus pais oficiais mecânicos". ${ }^{4}$ 


\section{Quadro 10:}

Famílias senhoriais e de conquistadores no senado da câmara (1567-1700)

\begin{tabular}{lc|c|c|c|c|c|c|c|c|c|c|c}
\hline Fam. & $\begin{array}{l}1567- \\
1620\end{array}$ & $\% \mathbf{a}$ & $\% \mathbf{b}$ & $\begin{array}{l}1621- \\
1661\end{array}$ & $\% \mathbf{a}$ & $\% \mathbf{b}$ & $\begin{array}{l}1662- \\
1700\end{array}$ & $\% \mathbf{a}$ & $\% \mathbf{b}$ & $\begin{array}{l}1567- \\
1700\end{array}$ & $\% \mathbf{a}$ & $\% \mathbf{b}$ \\
\hline Conq. & 39 & 73.6 & 36.4 & 62 & 60 & 35 & 73 & 55.3 & 44.2 & 174 & 60.2 & 38.7 \\
Fam. Sr.(a) & 53 & 100 & 49.5 & 104 & 100 & 58.7 & 132 & 100 & 80 & 289 & 100 & 64.4 \\
Totais (b) & 107 & & 100 & 177 & & 100 & 165 & & 100 & 449 & & 100 \\
\hline
\end{tabular}

Obs.: Fam. Sr - familia senhorial; Conq. - Conquistadores

Fontes: Anexo 1; Belchior, op. cit., pp. 511 e 512; AHU, av, cx.1, doc. 8; IHGB, t. 88, v. 142, p.396; IHGB, t. 93, v. 147, p. 261; IHGB, t. 95, v. 149, p. 347; RUDGE, R, op. cit.; TOURINHO, E. 1929, Autos de Correiçōes dos Ouvidores do Rio de Janeiro, vol.1, Rio de Janeiro, Prefeitura do Distrito Federal, 1929; RIO DE JANEIRO, op. cit., 1935.

Tais facilidades da elite não se limitavam à fixação dos preços dos produtos da terra. $\mathrm{O}$ mesmo ocorria com aqueles gêneros vindos do além-mar e que, a princípio, pertenciam ao exclusivo colonial e, portanto, cujas vendas na Colônia deveriam resguardar os interesses e lucros do capital mercantil reinol. Nesta rubrica incluem-se os tradicionais vinhos portugueses. Desconhecendo ou não tais princípios gerais do pacto colonial, em 1642, "acordarão os oficiais da câmara que o vinho (...) de Lisboa [se venda a] dois cruzados e dai para baixo e do porto de Viana e mais partes o bom a duas patacas para baixo". ${ }^{95}$

Da mesma forma, o senado interferia numa área ainda mais delicada da tradicional transferência do excedente colonial para a Metrópole: o preço do açúcar e dos fretes. Reunidos em vereança, no ano de 1642, os oficiais narram os acontecimentos que afligiam a cidade e seu distrito:

(...) nesta cidade se havia feito e ordenado entre os homens mercantis, capitães e mestres de navios e os mais que tratarão de comprar açúcares para carregarem para o Reino um monopólio (...) combinando-se de comum conformidade a não quererem comprar os ditos açúcares nem recebê-los em pagamentos das dívidas dos que (...) lhes deviam e estavam obrigados a pagar (...) senão por um preço tão baixo e diminuto que não era possível sendo 
que se continua-se deixarem de se perder e ficarem destruídos os engenhos, partidos e mais lavouras dos moradores.

Como resposta a esta situação, os oficiais da câmara e "demais pessoas nobres do governo desta República" decidiram tabelar o preço do açúcar e "pelo dito preço serão obrigados os acredores a toma-lo em pagamento de suas dividas". ${ }^{96}$ Deste modo, além dos interesses de Amsterdã e de Lisboa, os coloniais, ou melhor, os senhores de engenho, interferiam também nos preços da economia das plantations através de seu senado. Assim sendo, o chamado pacto colonial, ao que parece, não era tão poderoso na determinação da vida dos coloniais. Os preços do pacto poderiam ser negociados. Ainda em finais do século XVII, o senado reivindicava o direito de continuar interferindo no preço do açúcar. Numa carta datada de 1698, os oficiais defendem a "antiga" prerrogativa da câmara como fórum de negociação de tal preço entre os homens de negócio e os lavradores. ${ }^{97}$

Com a instalação da Companhia Geral do Comércio, em 1649, as relações entre o senado e o capital mercantil ultramarino tonaram-se mais tensas. Além de receber o privilégio de transportar o açúcar para Portugal, ela adquire o monopólio para o fornecimento de farinha, vinho, bacalhau e azeite ao Brasil, a preços por ela mesma estabelecidos, ${ }^{98}$ e ainda consegue a proibição do fabrico da aguardente da terra, produto concorrente do vinho luso. Neste mesmo ano, a câmara voltaria a fixar, contra a opinião do governador geral do Brasil, o Conde Castello Melhor, os preços dos gêneros. Desta vez, eram os quatros mantimentos negociados pela Companhia. A razão alegada para isto fora o estado de miséria da praça e a arbitrariedade da Companhia. ${ }^{99}$ Dois anos depois, numa carta datada de 1651, o governador do Rio e sua câmara insistiam em relatar a falta de navios para o açúcar e o estanque dos quatro produtos como as razóes para a miséria do povo e do presídio. Na mesma carta foi alegado que não tinha sentido o estanque da farinha, já que o Rio era abastecido por São Paulo. Entre os signatários pela câmara temos Francisco da Costa Barros e Aleixo Manuel, ambos membros de famílias senhoriais e descendentes de conquistadores. Em 1654, o senado enviaria várias reivindicaçōes, entre elas, a volta do comércio livre e o fim dos estanques daqueles produtos. Nesta correspondência, a câmara lembra ao rei que "esta cidade que a respeito de todo Reino he 
hum ponto invisivel, concorreu para empreza de Angola com oitenta mil cruzados, não emprestados mas dados por donativo, com muita boa vontade e liberal animo, com os quaes se prestára a Armada que vinha desfabricada de tudo, e conseguiu mediante Deos, a restauração daquelle Reino". ${ }^{100}$

Como resultado das pressóes dos colonos brasileiros e das comunidades de comerciantes dos pequenos portos portugueses, em um alvará datado de 1658 , o rei abolia o estanque dos quatros gêneros e, na década seguinte, a Companhia. perderia parte de sua força. ${ }^{101}$

Por estes acontecimentos, percebe-se a capacidade de enfrentamento da elite senhorial diante das pretensões metropolitanas de imporem certos traços do pacto colonial. Além disso, nota-se também um fenômeno nem sempre comum, uma certa unidade de interesses entre os diferentes segmentos desta mesma elite. Nas reivindicações da década de 1650, Pedro de Souza Pereira apareceria lado a lado a pessoas de "bandos" inimigos seus como João de Castilho Pinto e Aleixo Manuel.

As tensões entre os interesses metropolitanos e da elite, por seu turno, continuariam nas décadas posteriores. Numa carta de 1678, o senado da câmara relata ao rei que mandara prender, por seu juiz ordinário, o capitão Ignácio da Silveira Soutomaior, além dos mestres, parentes e procuradores dos senhorios dos navios das frotas. Estes últimos, não teriam procedido de forma correta no estabelecimento dos preços das mercadorias desembarcadas no porto. Na mesma correspondência, os oficiais da câmara solicitam que os fretes sejam estabelecidos na câmara, "como cabeça da república para o bem comum para proteger os moradores da capitania contra pressôes". ${ }^{102}$ Para evitar qualquer ilusão quanto às intenções dos referidos camaristas, deve-se lembrar duas coisas: no ano de 1678, dos cinco membros do senado que conheço, todos pertenciam a famílias senhoriais, das quais três descendiam de conquistadores e havia o mesmo número de donos de engenho. Portanto, eles legislavam em causa própria. Como donos de moendas, seriam os "moradores" mais interessados no controle sobre os fretes, entre os ditos oficiais.

Além dos preços do açúcar e dos fretes adstritos à elite senhorial, através do senado procurava-se também decidir sobre outro setor delicado da reprodução da economia da plantation, a saber, o tráfico atlântico de escra- 
vos. Entre as queixas enviadas à Lisboa no ano de 1669, encontramos denúncias contra os traficantes que preferiam enviar cativos angolanos para a Bahia e Pernambuco, em detrimento do Rio. Diante deste quadro, solicitava-se ao rei a possibilidade dos moradores do Rio enviarem, todos os anos, três navios negreiros para Angola, sendo este comércio feito sem a interferência dos ministros desta última Conquista. Talvez mais interessante que a parte final de tal pedido, seja o fato de que a Câmara reivindicava para si o direito de escolher os moradores donos de navios que teriam tal privilégio. Em outras palavras, a elite senhorial arrogava para si o direito de escolha e, portanto, de controle dos mercadores que teriam a chance de monopolizar parte do abastecimento de escravos. Como resposta, o Conselho Ultramarino determinou que dois navios do Rio poderiam realizar tal tráfico. ${ }^{103}$

Uma outra área de interferência do Senado era a administração de impostos. Até 1690, nesta condição, existiam pelo menos três impostos, todos criados para a defesa militar da cidade: do subsídio grande dos vinhos, instituído desde 1641; o do subsídio pequeno dos vinhos, formado em 1656 e o da aguardente da terra, votado em 1661. Pela administração destes impostos, os camaristas recebiam propinas e, além disso, há denúncias de pactos com comerciantes que resultavam em prejuízo para a arrecadação. ${ }^{104}$

Existindo ou não tais pactos, o fato é que a administração sobre determinados impostos possibilitava ao Senado ter uma ascendência direta sobre parte da riqueza da cidade, na forma de seu erário. Em 1686, os rendimentos da fazenda foram da ordem de 16:876 $\$ 666$, dos quais 2:930\$000 ou $17,4 \%$ estariam sob a tutela direta do senado. ${ }^{105}$ Repare-se que neste ano como em outros, o provedor da fazenda real e os escrivães da fazenda eram senhores de engenho, descendentes de conquistadores e, tiveram assentos na governança da cidade. Como ministros e oficiais da fazenda, estes senhores controlavam a arrecadação dos impostos devidos ao rei e, como membros ou aparentados de membros do Senado, administravam os outros impostos da cidade. Por conseguinte, isto ilustra mais uma vez a possibilidade dos descendentes de conquistadores, transformados em senhores, de terem o domínio das chaves do tesouro colonial.

Há ainda outros aspectos da vida econômica colonial tutelados pelos homens da governança da terra, para os quias gostaria de chamar a aten- 
ção. Trata-se dos bens e de setores da economia da República concedidos em arrendamento pela câmara. Em 1614, "os oficiais da câmara da dita cidade por entenderem que convinha ao prol do bem comum dela e aos mercadores e passageiros que a ela iam carregar açúcares e outras mercadorias ordenaram que houvesse na dita cidade uma casa de peso onde se pesassem todas as ditas mercadorias". Esta licença foi concedida a Aleixo Manuel, o Moço, "por tempo de tres nove anos dentro dos quais não poderá pessoa alguma fazer outro Passo nem ter peso nelle". ${ }^{106}$ Tal contrato demonstra que, da mesma maneira que em outras sociedades do Antigo Regime, o senado controlava, e portanto tinha a chance de arrendar, segmentos vitais para o funcionamento da vida econômica pública. Na prática, licenças como esta colocavam, nas mãos de determinados grupos de cidadãos, aspectos fundamentais da vida de toda a República. No caso específico, uma parte respeitável do comércio do recôncavo, inclusive o seu principal produto, teria que passar, obrigatoriamente, pelas dependências de Aleixo Manuel. Não é necessário insistir muito no que isto representava em termos de enriquecimento para o felizardo.

Aleixo Manuel pertencia à família extensa de conquistadores dos Homem da Costa, uma das que mais tiveram assento no Senado. Ao longo do século XVII, num documento de 1645, o capitão-mor da frota do Rio de Janeiro e contratador dos dízimos, Gaspar Dias de Mesquita, queixa-se da soberba dos membros de tal "bando" e afirma que Aleixo Manuel é o "mais aparentado homem que nela há" ${ }^{107}$ Entre os oficiais que deram aquele privilégio em 1614, voltamos a encontrar outras pessoas também muito aparentadas na terra: os capitães-de-fortalezas João Gomes da Silva e Pedro Gago da Câmara.

Em 1635, o domínio do Passo (sic) e da balança da cidade (trapiche) seria arrendado ao Alcaide Salvador Correia de Sá e Benevides. Neste contrato entre a Câmara e Salvador era estipulado: primeiro, que "não haverá outro paço nem peso desta cidade senão o sobredito"; segundo, "que querendo elle alcaider mor acabado o dito tempo aforar de novo o dito pezo e paso se the dara a elle tanto por tanto antes que a outrem". Ao que parece, Salvador e herdeiros quiseram renovar o dito aforamento. É isso que pelo menos se depreende de um escrito da Viscondessa de Asseca, datado de 1692, onde protesta contra a construção de um outro trapiche, e lembra que a sua fa- 
mília é a única que possui o privilégio de pesar o açúcar da cidade, ou seja, o seu principal produto de exportação. Em outras palavras, por mais de 50 anos, os Sá tiveram a chance de lucrar com cada caixa de açúcar que saía do porto do Rio. ${ }^{108}$

Tempos depois do contrato com Salvador Correia de Sá e Benevides, em uma das vereanças de 1643, ficava determinado que primeiro Baltazar de Leitão e depois Manuel Ribeiro Pasteleiro poderiam "dar a este povo toda a carne de vaqua que for necessaria para o sustento do dito povo". A exemplo dos contratos acima "nenhuma outra pesoa se lhe dara lisensa nê se consentira cortar carne se não os sobreditos sob as penas conteudas nas leis de sua mag. de o que tudo asi ordenarão por bem desta Republiqua". ${ }^{109}$

Sobre Manuel Ribeiro, Pasteleiro, nada sei. Contudo, o mesmo não ocorre com Baltazar Leitão. Casado com Feliciana de Pina, ele pertencia à família extensa fundada por Francisco de Pina, que fora provedor da fazenda real nas primeiras décadas do século XVII. Por duas vezes, pelo menos, Baltazar arrematara os dízimos reais. A primeira vez, em 1637, e a segunda, com seu genro, o dono de moendas Manuel Fernandez Franco, em 1649. ${ }^{110}$ Em seu inventário post mortem, de 1656, ele deixava um engenho de açúcar com 91 escravos de origem africana e 7 do gentio da terra. Este é um dos poucos inventários que tenho notícias para o Seiscentos e talvez, através dele, talvez se possa ilustrar a carreira de um membro da primeira elite senhorial do Rio de Janeiro. A família de Baltazar esteve ligada à administração da coroa e, portanto, às oportunidades dadas por uma economia do Antigo Regime para sua elite ou, mais precisamente, ao exercício de monopólios sobre setores básicos da República, no caso, o recolhimento de impostos e o abastecimento de carne. Provavelmente, tais oportunidades expliquem o tamanho do plantel de cativos no final de sua vida. Este plantel transformava Baltazar em um grande senhor de plantations para qualquer época da história da escravidão brasileira.

Os exemplos acima sugerem que não apenas o controle sobre os cargos da administração da coroa poderiam permitir a constituição de fortunas senhoriais. O Senado da Câmara encerrava a mesma possibilidade. Vimos no início deste artigo que a maioria das famílias senhoriais do século XVII foram constituídas até 1620 e que teriam sido inauguradas por ministros ou oficiais de sua Majestade. Mais adiante, no quadro 10, obser- 
vou-se que 60\% dos oficiais da câmara conhecidos entre 1565 e 1620 eram conquistadores e, ao mesmo tempo, ocupavam ou tinham exercido cargos da administração da coroa. Estas informações indicam que um contingente respeitável da futura elite senhorial, antes de ser dona de engenhos de açúcar, teria ocupado os postos de mando da sociedade colonial. Em outras palavras, aqueles postos teriam aberto oportunidades de enriquecimento. Em finais da primeira metade do Seiscentos, contudo, tal quadro sofreria certas mudanças. Constituída a elite senhorial com seus engenhos, apenas algumas famílias descendentes de conquistadores continuariam a ocupar postos estratégicos na administração real. Entretanto, o mesmo não ocorreria no senado.

No quadro 10, pode-se observar que determinadas famílias extensas originárias de conquistadores permaneciam na assembléia municipal ainda em finais do século XVII. Mais do que isto, no mesmo quadro, verificase que, com o passar do tempo, o Senado tenderia a se transformar de fato em fórum da elite senhorial — entendida como dona de engenhos de açúcar. Até 1620, pouco menos da metade dos oficiais da Câmara eram da elite e, depois de 1662, este número passaria para $80 \%$. Neste mesmo movimento, nota-se um crescimento da representação daquelas famílias oriundas de conquistadores. No primeiro período, eles correspondiam a um pouco mais de 35\% do total dos oficiais. No segundo, eles passariam para cerca de $45 \%$. Estes números demonstram a existência de um conjunto de famílias que, dentro da elite senhorial, persistiriam e insistiriam no controle de setores vitais da política e, portanto, da economia da República. Ao mesmo tempo, tal fenômeno dá consistência a expressões caras para estas pessoas, como o de nobreza da terra, de governança da República ou ainda de principais da terra.

\section{As melhores famílias da terra}

Era com este título, ou de nobreza e principais da terra, que tais descendentes de conquistadores gostavam de ser reconhecidos pela sociedade colonial. Tais expressões, como se sabe, não foram uma invenção das melhores famílias do Rio. Elas podiam ser encontradas no Portugal do Antigo Regime designando os homens bons que ocupavam os cargos concelhios, 
ou em Pernambuco seiscentista para identificar os senhores de engenho, principalmente aqueles que se envolveram nas lutas contra os holandeses e exerceram os "cargos honrados da República". ${ }^{111}$ Em ambos casos, portanto, nota-se que nobreza da terra aparece ligada ao poder político do município ou, ainda, aos "homens bons da terra". Entretanto, devemos ter alguns cuidados com estas expressões.

Antes de mais nada, se vamos às Ordenaçôes Filipinas, verifica-se que não há uma clara definição para esta designação. Segundo Cândido Mendes de Almeida, nestas leis, os homens bons eram considerados "os cidadãos que haviam ocupado os cargos das Municipalidades, ou governança", contudo, não explica como se "recorria a tais homens, no começo ou criação de uma vila”. Ao mesmo tempo, segundo Gonçalo Monteiro, a noção jurídica de nobreza em Portugal do Antigo Regime era extremamente fluida. Fenômeno que decorria, em parte, da relativa facilidade com que se processava o acesso às distinções nobiliárquicas. Como reação a isto, principalmente depois da Restauração (1640), notar-se-ia uma progressiva delimitação do núcleo restrito dos Grandes (alta aristocracia). Em finais do século XVII, as expressões de nobreza ou de fidalguia como grupo passariam a designar fundamentalmente os titulares do Reino. Acompanhando o mesmo processo, conforme ainda Monteiro, a noção de "principais da terra" e de "nobreza da terra" deixaria de se identificar com os senhores de terras com jurisdição. Isto ocorreria até porque os "Grandes da terra", ou o que é o mesmo, as casas aristocráticas mais antigas e ricas da província, furtavam-se do exercício dos cargos municipais. O horizonte social e político de tal grupo não se situava na província, mas sim na Corte, no serviço da monarquia. ${ }^{112}$

Ao que parece, no Rio de Janeiro, a expressão nobreza da terra estaria ligada à antigüidade da família no exercício do poder político-administrativo da cidade, e à descendência dos conquistadores. ${ }^{113}$ Vejamos alguns exemplos:

Em 1628, um dos membros destas famílias, João Castilho Pinto, fora definido pelos oficiais da Câmara como "uma das pessoas mais nobres da dita cidade e da governança dela”. Ou seja, João tinha condições de ter assento na assembléia municipal e de fato, pelo menos por três vezes, seria vereador ou juiz ordinário: em 1635, 1645 e 1651. Anos depois, o então gover- 
nador da cidade, Duarte Correia Vasqueanes, afirmava que João era "uma das mais nobres pessoas dela [Rio de Janeiro] mostrando sempre muito zelo do serviço de sua magestade". Na continuação da mesma carta, o governador esclarece que João era "bisneto legitimo de Francisco Dias Pinto primeiro Alcaide-mór proprietário que teve esta cidade (...) e bisneto legitimo de Jorge Ferreira Bulhóes capitão e ouvidor que foi dezoito anos da capitania de São Vicente e (...) filho legitimo de Manuel de Castilho, almoxarife que foi desta cidade". ${ }^{114}$ Por conseguinte, João era a terceira geração de uma linhagem de pessoas acostumadas com o poder.

No ano de 1643, alguns oficiais da câmara justificaram a concessão de chãos da marinha da cidade à Salvador Correia de Sá e Benevides alegando que ele "he hum homem fidalgo e alcaide mor desta cidade cujos avos pay e parentes a povoaram conquistaram e governaram desde seu principio" ${ }^{115} \mathrm{O}$ confronto entre estes dois senhores torna-se interessante, já que João Castilho Pinto e Salvador Correia de Sá eram inimigos capitais no início da década de 1640. Contudo, ambos foram identificados naquela época, da mesma forma, ou seja, ambos pertenciam a famílias originárias da conquista e ocuparam, por gerações, o mando da cidade e portanto, são nobres.

Em 1664, em meio a disputas no interior da elite senhorial, os oficiais da câmara lembravam que os candidatos à assembléia deveriam ser "das principais da terra e qualificados (...) se excluir delas todo homem mecânico e de baixa sorte e que só se admita na governança homens fidalgos". ${ }^{116}$ Dos seis camaristas que escrevem estas exigências, dois descendiam dos nossos conhecidos Pedro Gago da Câmara (ex-capitão de fortaleza e vereador em 1614), um do conquistador e ex-provedor da fazenda Antônio Mariz, e um outro pertencia à família extensa dos Homem da Costa. Portanto, no ano considerado, a maioria absoluta da Câmara era formada por famílias que dominavam a cena política da cidade, com passagens pelos postos de ministros e de capitães-da-infantaria paga, desde os primeiros tempos coloniais. Além disso, pelo mesmo documento, percebe-se que elas não estavam dispostas a abandonar tal cena. Portanto, não é difícil de se inferir o que eles entendiam por "principais da terra".

Pelo que escrevemos há pouco, percebe-se que a noção de nobreza da República não tem uma existência legal, no sentido de uma posição hierárquica superior referendada pela lei, como ocorre na sociedade estamental 
européia. Na verdade, no Rio de Janeiro, os "fidalgos" pagam impostos como outro qualquer mortal e da mesma forma, ao contrário de Portugal, não são senhores de terras com jurisdição. O que permite àquelas famílias senhoriais se arrogarem o título de nobreza no Recôncavo seria um sentimento que combina, pelo menos três ingredientes:

- Eles seriam descendentes de conquistadores, de um grupo de pessoas (ou de uma "raça") que, às custas de suas fazendas, guerrearam e submeteram terras e outros povos (gentio da terra e os inimigos europeus);

— Uma vez feito isto, desde esta época, exerciam os postos de mando da República.

- A conquista e o mando político lhes davam um sentimento de superioridade sobre os demais mortais/moradores da Colônia. Fenômeno este que era referendado pelas mercês dadas por Sua Majestade, pelos casamentos com pessoas do mesmo status e, talvez, principalmente, pelo contínuo reconhecimento dado pelos coloniais através da reiterada eleição destas famílias para os principais postos do Senado. Neste momento é importante lembrar que muitos dos acusados de corrupção não sofreriam punição do rei e nem o desrespeito da sociedade colonial (de alguns de seus setores, pelo menos). Este é o caso de Tomé de Souza Correia, acusado pelo governador da cidade de corrupto, em 1676, e que seria elogiado mais tarde, pelos seus bons serviços, pelo Senado. ${ }^{117}$

Aqui, talvez, tenhamos o pulo do gato, qual seja, a apropriação, para fins privados, dos bens e serviços públicos administrados pela coroa e o Senado. O "sentimento" de conquistadores (ou de seus descendentes), de mandatários da República e o reconhecimento social destas qualidades, justificaria o uso e apropriação dos bens e serviços públicos como coisa sua, isto é, como algo da nobreza da República. Isto fica mais claro, por exemplo, quando lembramos que, entre 1650 e 1700 , mais de $40 \%$ dos sesmeiros eram descendentes (direta ou indiretamente) dos conquistadores. No mesmo período, $60 \%$ dos senhores de engenho descendiam ou estavam casados com moças daquele grupo. Ou seja, ainda na segunda metade do século XVII, ingressar na elite senhorial passava, majoritariamente, pela descendência ou casamento com netas ou bisnetas dos primeiros povoadores e, nesta condição, se teria mais facilmente o acesso às terras da coroa. Em 
suma, a noção de nobreza da República se completa quando temos em conta que tal categoria se apropria e distribui entre si "os bens materiais" da mesma República.

\section{A economia do bem comum}

Para o bom governo da República, o Senado da Câmara do Rio de Janeiro concedeu monopólios sobre o corte da carne e o peso do açúcar, assim como tentou fornecer privilégios no tráfico atlântico de escravos. Antes, durante e depois de tais concessões concelhias o rei, também no interesse do bem comum, concedeu mercês para pessoas (ou seus descendentes) que incidiam sobre áreas essenciais do Reino e do Ultramar. Quando sua majestade nomeava um provedor da fazenda ou um capitão de infantaria, estava assegurando o comércio e a defesa militar dos seus súditos nas Conquistas, e por conseguinte, estava garantindo o bem estar de seus vassalos na República. Raciocínio semelhante poderia ser utilizado, quando da concessão de uma mercê na forma de privilégios comerciais. Estas eram dadas para aquelas pessoas cujos serviços, ou de seus antepassados, teriam defendido os interesses da coroa, e portanto do bem comum.

Um outro lado desta questão, é que tanto o Senado da Câmara e a Coroa (como cabeças da República) retiravam do mercado e da livre concorrência bens e serviços indispensáveis ao público, passando a ter sobre eles o exercício da gestão. Em outras palavras, entremeando e interferindo nas lavouras, comércio e artesanato dos moradores dos conselhos/súditos do rei teríamos, no Antigo Regime português, um conjunto de bens e serviços que poderiam ser identificados pelo nome de economia do bem comum, ou de economia da República.

Entretanto, para efeito deste artigo, a noção de economia do bem comum só fica completa quando consideramos que ela encerrava também uma forma particular de apropriação do excedente social. Os bens e serviços da República eram concedidos, pelo Senado e/ou pelo rei, para apenas alguns eleitos e tal privilégio era exercido na condição de monopólio ou de semi-monopólio. Os demais moradores/súditos que ousassem interferir em tais monopólios, seriam punidos pela lei. Um outro cenário era dos privilégios sobre certos setores do mercado: franquias fiscais no comércio, ou 
garantias legais no transporte de mercadorias. Somente alguns recebiam tais mercês e os que não as tinham, estariam sujeitos à lei e ao mercado. Desta situação de monopólio decorre a possibilidade daqueles eleitos se apropriarem, em regime de exclusividade ou com menor concorrência, dos rendimentos de segmentos da produção social. Trata-se de uma situação onde o "conjunto da população livre" (entendida no interior de uma sociedade hierarquizada de Antigo Regime) ou, o que é o mesmo, o público da República, deposita nas mãos dos escolhidos parte de seu rendimento. Era o público que, de uma maneira direta ou indireta, sustentava os eleitos da República.

Deste modo, além da acumulação de riquezas decorrente da produção camponesa em Portugal ou da escravidão das plantations, havia outro circuito de acumulação de rendas. Este último identificado com a República, e onde o produtor e fornecedor de rendas não era apenas o lavrador, ou comerciante ou o artífice, mas sim o conjunto de lavradores, de comerciantes e de artífices. Numa palavra, o público.

A partir dos últimos parágrafos, torna-se mais fácil o entendimento de noções que antes utilizei, como mercado imperfeito ou de acumulação excludente. Por outro lado, o uso da expressão de economia do bem comum merece certo cuidado. Como empreguei, ela diz respeito ao Antigo Regime português. Isto é, ela estaria presente em sociedades com estruturas sociais e econômicas distintas, como Portugal continental e o Recôncavo do Rio de Janeiro seiscentista.

Segundo A. Hespanha, o sistema de mercês reforçaria o caráter corporativo da monarquia portuguesa, de um tipo de "monarquia cujos encargos correspondem basicamente à estrutura feudal-corporativa do benefício". Para isto, basta lembrar que, em 1607, os gastos do Reino somente com tenças e moradias (pensóes dadas por serviços prestados) era de 190 contos, quantia bem superior aos 167 contos arrecadados pelo Estado, na mesma época, no império atlântico. ${ }^{118}$

Por sua vez, conforme Gonçalo Monteiro, em Portugal do Antigo Regime, e principalmente com os Bragança, teríamos uma aristocracia, no caso os Grandes, cujo ethos identificava-se com os serviços à monarquia. Ela não vivia principalmente da propriedade da terra ou de outros negócios particulares, mas vivia e retirava seus rendimentos dos serviços presta- 
dos à República, ou melhor, das mercês concedidas por tais serviços. Segundo o autor, tratar-se-ia de uma economia de serviços circular, onde a elite cortesã monopolizava os principais cargos e ofícios no paço, no exército e nas colônias. Como remuneração por tais serviços, ela recebia novas concessões régias que poderiam ser acumuladas e que também poderiam adquirir a forma de novos serviços, como a administração de mais bens da coroa ou de postos com mais prestígio. ${ }^{119}$

No Recôncavo do Rio de Janeiro, a distribuição de mercês, e posteriormente as concessões do senado entre os conquistadores e seus descendentes, viabilizaria uma acumulação de riquezas que mais adiante se transformaria em engenhos de açúcar, na própria economia das plantations. Estas mercês e concessões concelhias reforçariam as desigualdades econômicas e sociais, presentes na montagem da sociedade colonial. Além das desigualdades imprimidas pela Conquista através da escravidão do gentio da terra, teríamos aquelas introduzidas, entre os colonos europeus, pelo sistema de mercês. Deste modo, seria em meio à uma hierarquia social e econômica fortemente diferenciada que teríamos a produção dos recursos necessários à "acumulação primitiva" da economia da plantation. Em outras palavras, é o público colonial (seus lavradores, comerciantes, mamelucos, gentio da terra, escravos de origem africana etc.) que paga parte das contas da instalação dos engenhos, e o faz tendo parte de sua produção social apropriada, via acumulação excludente, por uma elite de conquistadores.

Uma vez concluída a instalação da produção colonial em meio aos engenhos, lavouras de alimentos e currais de gado, os mecanismos da economia do bem comum continuariam agindo. $\mathrm{O}$ controle da elite senhorial sobre a política, ou mais especificamente, sobre o Senado e parte da administração da coroa, facultar-lhe-ia o contínuo exercício de uma acumulação excludente. Para isto, basta lembrar a insistência das famílias senhoriais descendentes dos conquistadores no domínio sobre o Senado, ou ainda recordar a permanência dos Correia, dos Pontes e dos Frazão de Souza a frente dos postos da administração da coroa. A elite senhorial não era uma nobreza no sentido europeu como vimos, entretanto, ela foi capaz de articular, na prática e através da política, privilégios que lhe garantiam a apropriação de segmentos da riqueza social, sendo estes privilégios passados de 
geração para geração. Na verdade, no Rio de Janeiro seiscentista percebese uma inversão da máxima de Weber sobre a administração tradicional, segundo a qual os administradores viviam para a política sem dela ter de viver. No Rio de Janeiro do século XVII, os administradores vivem da política, e através do controle da economia da República se apropriam de parte da produção social.

O fato do domínio sobre a economia do bem comum se fazer na política, invariavelmente gerava disputas políticas. Segundo Gonçalo Monteiro, a distribuição de ofícios superiores e de mercês, portanto de instrumentos que possibilitavam o aumento do prestígio social e da acumulação de riquezas, geralmente era acompanhada por conflitos entre os Grandes da aristocracia lusa. ${ }^{120}$ Algo semelhante também ocorria no Rio de Janeiro seiscentista, nas eleições para o Senado, na distribuição dos privilégios concelhios, e no acesso aos cargos da administração real. Estas esferas eram espaços, por excelência, das disputas no interior da elite senhorial. Isto ocorre até porque nem todas as antigas famílias senhoriais permanecem, simultaneamente, nas duas principais esferas de poder da sociedade colonial, a administração periférica da coroa e o Senado.

Algumas famílias permaneceriam, majoritariamente, na primeira esfera enquanto que outras tenderam a ter mais presença no Senado. Isto, entretanto, não significa que a cena política da cidade tenha sido marcada, a partir de uma determinada data, pelo conflito Câmara versus ministros. Em realidade, o que se observou foi a transformação da capitania num cenário de disputas intra elite senhorial pelo controle político da República e, conseqüentemente, dos "bens" e benefícios que ela representava.

Um dos exemplos destas disputas são as contínuas denúncias contra a interferência dos ministros do rei nas eleições do Senado (1648, 1655, 1660 61, 1668, 1686 etc. — ver AHU, ca). Curiosamente, denunciantes e denunciados, quase sempre pertenciam ao mesmo grupo social. Tal é o caso da revolta de 1660-61. Os ministros acusados eram da família Correia (inclui-se aqui Pedro de Souza Pereira e setores dos Pontes) e dois dos lideres da rebeliāo, o capitão Diogo Lobo Pereira e Jorge Ferreira Bulhões, descendiam de conquistadores, e um terceiro (Jerônimo Bezerra Barbalho) era filho de ex-governador da cidade. Trata-se, portanto, de desavenças no interior da elite local. 
O pano de fundo destas rivalidades pode ser insinuado na carta levada pelo procurador da Câmara, e também provedor dos defuntos e ausentes, João Castilho Pinto à Lisboa na década de 1640. Após ter relatado ao rei os abusos de Salvador Correia de Sá e Benevides, do provedor da fazenda Pedro de Souza Pereira e dos demais oficiais da alfândega de desvios na fazenda e alfândega reais, o mesmo denunciante solicita a sua majestade a capitania da fortaleza de São Sebastião e, em especial, o cargo de juiz da balança, cargo já ocupado por Salvador Correia de Sá e Benevides desde 1635. ${ }^{121}$ Portanto, um dos pontos de tal desavença era o controle do trapiche e da balança do açúcar, um dos "bens" mais preciosos da República.

Se o controle sobre a administração real periférica (e de suas benesses) muitas vezes fugia das mãos da elite senhorial (já que na nomeação para os cargos a última palavra dependia de Lisboa), o mesmo não ocorria com o Senado. O que, como já vimos, em termos da economia do bem comum, não era pouca coisa. Afinal, o controle sobre a assembléia municipal significava poder interferir nos preços, no açougue, na balança do açúcar etc. Daí se entende a constatação do governador Francisco Soutomaior, em 1645, de que "as eleiçôes do senado eram dominadas por pessoas da facção dos Correias [Salvador Correia de Sá e Benevides] e dos Manoes [Aleixo Manuel, o moço] que são dois Bandos e parcialidades de que nesta resultam tantas monstruosidades tão prejudiciais ao serviço de Deus e de sua Magestade". ${ }^{122}$

Por seu turno, as observações do assustado governador Soutomaior apresentam um componente essencial para o domínio sobre a economia da República: as redes de alianças políticas (parentesco, clientelas etc.).

A presença destas redes nas disputas do mando colonial pode ser ilustrada através dos acontecimentos de 1642, que resultaram no afastamento temporário de Salvador Correia de Sá e Benevides do posto de governador. Entre os que defenderam Salvador em juízo, encontramos o senhor de engenho Jorge Fernandes da Fonseca, membro da família extensa Homem da Costa, e Diogo Sá da Rocha, também dono de moendas, antigo ouvidor-geral e genro dos Rangel. Do lado oposto, voltamos a achar velhos inimigos: Aleixo Manuel e os Pinto Castilho.

Ao mesmo tempo, os acontecimentos de 1642 apresentam um outro aspecto das alianças políticas: a fluidez. Os dois envolvidos diretamente na 
disputa pelo governo da cidade, Salvador e Duarte Correia Vasqueanes, eram respectivamente sobrinho e tio. Jorge Fernandes da Fonseca e Aleixo Manuel, neste momento em lados opostos, eram cunhados. Por conseguinte, não só as alianças poderiam mudar conjunturalmente, como também podiam existir interesses divergentes dentro de uma mesma família. Quanto a este último ponto, não parece ter sido a regra geral. Ao que tudo indica, pelo menos os parentes mais próximos tendiam a agir em comum e da mesma maneira. O casamento selava alianças entre famílias. Um bom exemplo disto foi o assassinato de Pedro de Souza Correia. Segundo a devassa feita na época os culpados seriam os "Amaraes [família senhorial] e seus aliados" encabeçados por Francisco do Amaral. Entre os suspeitos teríamos, além dos tios, irmãos e primos de Francisco, dois genros da família que eram também senhores de engenho. ${ }^{123}$

Um exemplo do envolvimento de tais redes nos negócios da República pode ser dado pela narrativa feita por Antônio Mendes de Almeida, nas suas palavras, "um homem forasteiro e sem parentes na terra". Segundo Antônio, no ano de 1686, ele fora preterido do contrato dos dízimos, devido às armaçôes do provedor da fazenda real, Pedro de Souza Correia e de "seus amigos". Antes de mais nada, Antônio acusava ter sido impedido de participar de tal arrematação, através de artifícios montados pelo provedor da fazenda, o ouvidor-geral da cidade, e do juiz ordinário Baltazar de Abreu Cardoso. Uma vez feito isto, o mesmo provedor, por meio de um criado seu, arremataria os dízimos, e nisto fora auxiliado por Manuel Fernandez Franco, Antônio de Abreu de Lima e Francisco Gomes Ribeiro. O primeiro teria adquirido o contrato para depois passá-lo para a criatura do provedor, e os dois últimos serviram como fiadores do mesmo criado. ${ }^{124}$ Vejamos quem eram alguns destes "amigos". O juiz ordinário era senhor de engenhos e neto de Jorge Fernandes da Fonseca, o mesmo que tempos antes fora procurador de Salvador Correia de Sá e Benevides. Manuel Fernandez Franco, que já tivemos o prazer de conhecer, pertencia à família extensa Pina e, por diversas vezes, esteve envolvido na arrematação de impostos. Antônio de Abreu de Lima e Francisco Gomes Ribeiro também pertenciam à elite senhorial. O primeiro, com auxílio de Pedro de Souza Correia, tivera a serventia do juizado de órfãos, e o segundo, em 1678, chegaria ao 
posto de capitão-mor de Cabo Frio. Deste modo, percebe-se que, nestes acontecimentos, a família Frazão de Souza aparece escudada por uma aliança formada com mais quatro famílias senhoriais.

Um dos mecanismos geradores de alianças era a constituição de clientelas. Os governadores tinham a possibilidade de nomear, mesmo que provisoriamente, pessoas para cargos da administração civil e militar da colônia. Neste sentido, foram exemplares as carreiras de Pedro de Souza Pereira e de Diogo Lobo Teles antes de se tornarem, respectivamente, proprietários dos ofícios de provedor da fazenda e de juiz de órfãos. Ambos foram capitães de infantaria e depois, sempre por nomeações dos Correia, seriam capitães-da-fortaleza de Santiago e capitães-mores das frotas do Rio para Lisboa. ${ }^{125}$ Como já vimos, ao longo de sua carreira, Pedro se casaria com uma Correia e o mesmo ocorreria com um dos sobrinhos de Diogo. Algo semelhante talvez, possa ser dito para outros capitães-de-fortaleza e da infantaria paga. Manuel da Costa Cabral, capitão-da-fortaleza de Santa Cruz em 1669, teve uma de suas filhas casada com Martim Correia de Sá. Alexandre de Castro, capitão-da-infantaria paga desde 1644, tornou-se esposo, em 1639, de Felipa de Sá, membro da casa de Salvador Correia de Sá e Benevides. Ascenso Gonçalves de Matoso, capitão da fortaleza de São João e membro de uma família senhorial, desde 1655 estava casado com Serafina Correia de Sá.

Não era inteiramente sem motivo que os "Manoeis", Correias e depois os Pontes fossem considerados poderosos por serem os "mais aparentados nesta terra”. Através das suas clientelas e estratégias de casamento estas famílias ampliavam as suas esferas de influência. ${ }^{126}$

$\mathrm{Na}$ verdade, a importância das redes de parentesco no funcionamento da economia e sociedade coloniais ultrapassava em muito o que chamei de economia do bem comum. ${ }^{127}$ Para tanto, basta lembrar seu impacto sobre o mercado colonial. Entre 1650 e 1669, 1/4 das vendas e compras de engenhos, em cartório, foram feitas entre parentes (sogro/genro, pai/filho, irmão/irmão etc.). No meio de tais compras, a concretização de dotes, ou seja, de alianças familiares. Caso comparemos, em 1665, os valores de todos os dotes do ano com aqueles totais negociados nas compras e vendas em cartório, verificaremos que a soma dos primeiros corresponderam a $42 \%$ 
de todas as vendas. Portanto, nesse ano, os dotes tiveram um peso equivalente do mercado na transferência da propriedade (terras, engenhos, casas etc.) de uma família para outra. ${ }^{128}$

\section{Conclusão: a exclusão como pecado original}

Em suma, a montagem da economia das plantations no Rio de Janeiro se daria numa conjuntura favorável em termos de preços do açúcar no mercado internacional, não sendo, contudo, tão propícia para Portugal e seu império. Desde meados do quinhentos o ultramar luso estaria sendo atacado nos seus diferentes quadrantes e o Reino, na mesma época, sofreria as desventuras das crises de subsistência, da recorrência das pestes, do aumento do déficit público etc. Em meio a este cenário, a solução para a formação das estruturas produtivas do Rio de Janeiro seria dado pelo já conhecido receituário do Antigo Regime português. Qual seja: a conquista de terras e de homens; o sistema de mercês; e o Senado da Câmara. Caberia aos conquistadores, agora transformados em funcionários do rei e em camaristas, dirigir a gestação da nova sociedade nos trópicos. E nisto eles se superariam. Através dos seus cargos, de suas redes de parentesco e de clientela, eles (e seus descendentes) construiriam engenhos e, com isto, se transformariam na primeira elite senhorial da sociedade escravista e agroexportadora do Rio. Na verdade, através da carreira destes senhores e da economia da qual eles eram mandatários pode-se perceber um dos preceitos básicos da velha sociedade lusa. Isto é, uma hierarquia social profundamente desigual permitindo a produção - e, via política, a apropriação — de parte da riqueza social.

Por seu turno, até por que a montagem da produção colonial se dá dentro dos cenários do Antigo Regime, este movimento, simultaneamente, criaria "uma nobreza da República", cujas bases eram o mando político e a apropriação daquilo que chamei de "economia do bem comum". Esta economia seria formada por bens e serviços públicos sob a jurisdição do Senado e do rei, porém administrados por poucos eleitos, mas custeados por todos os colonos. Tal quadro, por decorrer do controle da política e se traduzir numa acumulação econômica excludente, se decidia na disputa política e se assentava em vastas redes de parentesco e de clientela. 
Esta nobreza - descendente de conquistadores e formada por donos de engenhos que também podiam se dedicar ao comércio - e suas formas de acumulação não foram os únicos caminhos para o enriquecimento no Seiscentos. Afinal, como alguém já disse, o comércio é uma atividade antediluviana, ou seja, existia mesmo antes de Noé e sua arca. Portanto, é certo que alguns colonos transformaram-se em donos de engenho, principalmente por meio do comércio. Entretanto, mesmo estes tiveram que lidar com um mercado onde a Câmara interferia nos preços e os ministros do rei faziam estanques de mercadorias.

Por último, é também certo que aquela nobreza e suas práticas, como fenômenos majoritários, em algum momento da história colonial cederiam espaço para outras relações sociais. Afinal, em finais do século XVIII, a elite econômica (aquela que controla o tráfico de escravos e a liquidez do sistema, entre outros setores) são os comerciantes de grosso trato. Contudo, a prática da exclusão social do público (para além da população cativa) continuaria como uma das chaves para a acumulação de riquezas.

\section{Fontes manuscritas}

ACRJ - Arquivo Geral da Cidade do Rio de Janeiro (Brasil), Cartório do $1^{\circ}$ Ofício de Notas do Rio de Janeiro, 1612-1698. Tipos de escrituras (E): CVcompra e venda; Pro- procuração; H- hipoteca e didinheiro a ganho; CoConhecimento; Q- quitação; P- partido; T- transmissão; Per- permuta; Testtestamento; Fiança

AMSB - Arquivo do Mosteiro de São Bento, Rio de Janeiro (Brasil); inventários e testamentos.

AN - Arquivo Nacional, Rio de Janeiro (Brasil), — Cartório do 10 Ofício de Notas do Rio de Janeiro. Escrituras Públicas: 1610-1698.

- 1680. Correspondência dos Governadores Rio de Janeiro. Provisão Régia. Códice 77, Livro. 10, p. 54.

- 1702. Correspondência dos Governadores Rio de Janeiro. Cartas. Códice 77.Livro 13.

AHU - Arquivo Histórico Ultramarino, Lisboa (Portugal).

— Rio de Janeiro: ca — Coleção Castro Almeida; av — Avulsos; Códices 115 e 1279. 
- Angola: 1695, Cx. 15, doc. 36

Arquivo da Torre do Tombo (Portugal): Chancelaria de Filipe II, liv. 16; Chancelaria de Filipe III, Doações, liv. 32

\section{Fontes publicadas}

AN 1911. Arquivo Nacional. Publicaçōes, XI, Rio de Janeiro: Arquivo Nacional. BN, DH, Biblioteca Nacional, Documentos Históricos, vol. 16 a 34, Rio de Janeiro. Couto, D. s/d, O Soldado Prático, Lisboa: Edições Europa-América

Frei Vicente Salvador. 1982. História do Brasil, Belo Horizonte: Ed. Itatiaia; São Paulo: Ed. da USP

Ordenações Filipinas 1985. Livro 1, Lisboa: Fundação Calouste Gulbenkian, 1985 IHGB — Instituto Histórico Geográfico Brasileiro.

Rio de Janeiro 1935. Diretoria Geral do Patrimônio, Estatística e Arquivo. O Rio de Janeiro no sec. XVII - Acordōes e Veranças do Senado e da Câmara, 1635-1650 Tourinho, E. 1929. Autos de Correiçôes dos Ouvidores do Rio de Janeiro, vol.1 (1241699). Rio de Janeiro: Prefeitura do Distrito Federal.

\section{Anexo 1:}

\section{Fundadores e primeiros senhores de engenho das família} senhoriais do Rio de Janeiro

\begin{tabular}{|c|c|c|c|c|c|}
\hline Tipo & fundador da Fam. Sr. & $1^{\mathrm{o}}$ sr. de engenho & Cas & Patente* & Fonte \\
\hline 1 & Belchior Pontes & & 1580 & & \\
\hline 2 & André da Silveira & André da Silveira & 1599 & & RUDGE \\
\hline & Villalobos & Villalobos & & & (1983) \\
\hline \multirow[t]{2}{*}{2} & Belchior Andrade & & 1616 & Cap.Inf. & \\
\hline & & $\begin{array}{l}\text { Franc. Andrade } \\
\text { e Araujo }\end{array}$ & 1648 & Meir.Mar & $\begin{array}{l}\text { ACRJ- } \\
\text { ECV, } 1691\end{array}$ \\
\hline \multirow[t]{2}{*}{2} & Diogo Aires Aguirre & & $1620 ?$ & Capmor & \\
\hline & & $\begin{array}{l}\text { Domingos Aires } \\
\text { Aguirre }\end{array}$ & 1650 & & $\begin{array}{l}\text { Araujo } \\
(1901)\end{array}$ \\
\hline 2 & $\begin{array}{l}\text { Fernão Faleiro } \\
\text { Homem }\end{array}$ & $\begin{array}{l}\text { Fernão Faleiro } \\
\text { Homem }\end{array}$ & 1646 & Cap.Fort & $\begin{array}{l}\text { ACRJ- } \\
\text { ECV, } 1653\end{array}$ \\
\hline
\end{tabular}




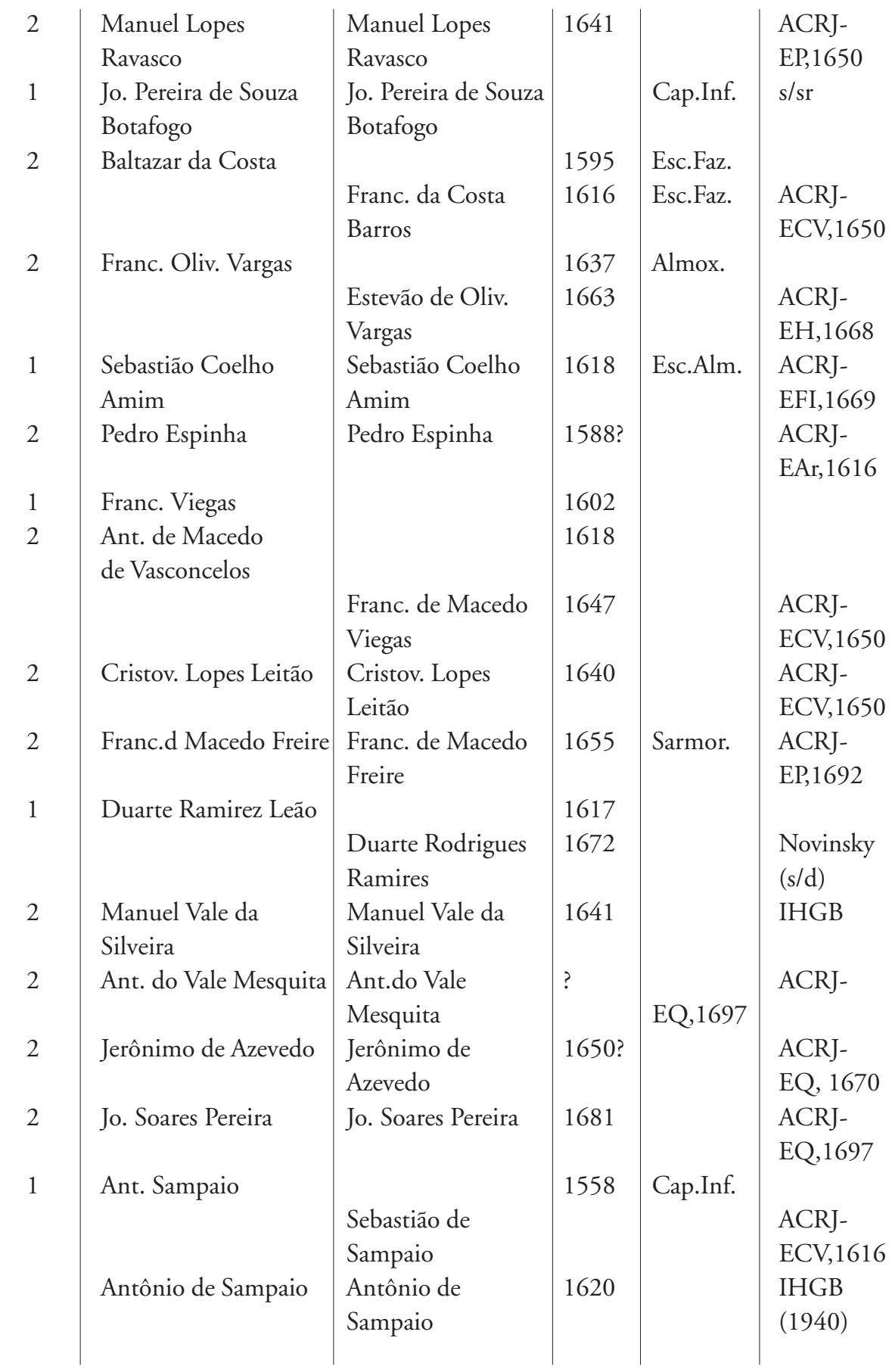


A nobreza da República $\bullet 105$

\begin{tabular}{|c|c|c|c|c|c|}
\hline 2 & $\begin{array}{l}\text { Agoostinho Pimenta } \\
\text { de Moraes }\end{array}$ & $\begin{array}{l}\text { Agostinho Pimenta } \\
\text { de Moraes }\end{array}$ & 1652 & & $\begin{array}{l}\text { ACRJ- } \\
\text { AR,1689 }\end{array}$ \\
\hline 1 & Diogo Sá da Rocha & Diogo Sá da Rocha & 1613 & Ouvidor & $\begin{array}{l}\text { ACRJ- } \\
\text { ECV }, 1650\end{array}$ \\
\hline 2 & Franc. de Gouveia & Franc. de Gouveia & ? & & $\begin{array}{l}\text { ACRJ- } \\
\text { ECV }, 1650\end{array}$ \\
\hline \multirow[t]{2}{*}{2} & \multirow[t]{2}{*}{ Manuel Barbosa Pinto } & & 1628 & & \\
\hline & & $\begin{array}{l}\text { Diogo de Sá } \\
\text { da Rocha }\end{array}$ & 1664 & & $\begin{array}{l}\text { ACRJ- } \\
\text { ECV,1665 }\end{array}$ \\
\hline 2 & Jacinto da Guarda & Jacinto da Guarda & $1614 ?$ & & $\begin{array}{l}\text { ACRJ- } \\
\text { ECV }, 1650\end{array}$ \\
\hline 1 & Manuel Leitão & Manuel Leitão & 1616 & & $\begin{array}{l}\text { ACRJ- } \\
\text { EQ,1665 }\end{array}$ \\
\hline 2 & Cust. Coelho Madeira & $\begin{array}{l}\text { Cust. Coelho } \\
\text { Madeira }\end{array}$ & 1643 & Cap.Pres & $\begin{array}{l}\text { ACRJ- } \\
\text { EP,1662 }\end{array}$ \\
\hline 1 & Toussaint Grugel & Toussaint Grugel & 1606 & & $\begin{array}{l}\text { ACRJ- } \\
E Q, 1662\end{array}$ \\
\hline 2 & $\begin{array}{l}\text { Claude Antoine } \\
\text { Besançon }\end{array}$ & $\begin{array}{l}\text { Claude Antoine } \\
\text { Besançon }\end{array}$ & 1626 & & $\begin{array}{l}\text { ACRJ- } \\
\text { EP,1653 }\end{array}$ \\
\hline 2 & $\begin{array}{l}\text { Felix Correia de } \\
\text { Castro Pinto }\end{array}$ & $\begin{array}{l}\text { Felix Correia de } \\
\text { Castro Pinto }\end{array}$ & 1673 & & $\begin{array}{l}\text { Novinsky } \\
\text { (s/d) }\end{array}$ \\
\hline \multirow[t]{2}{*}{1} & $\begin{array}{l}\text { Jo. Gonçalves } \\
\text { de Azevedo }\end{array}$ & & 1608 & Alf.Fort & \\
\hline & & $\begin{array}{l}\text { Afo. Gonçalves } \\
\text { de Azevedo }\end{array}$ & 1638 & & $\begin{array}{l}\text { ACRJ- } \\
\text { EFI,1663 }\end{array}$ \\
\hline 2 & $\begin{array}{l}\text { Estevão Tourinho } \\
\text { Pacheco }\end{array}$ & $\begin{array}{l}\text { Estevão Tourinho } \\
\text { Pacheco }\end{array}$ & 1629 & Alf.Fort & $\begin{array}{l}\text { ACRJ- } \\
\text { EFI,1663 }\end{array}$ \\
\hline \multirow[t]{2}{*}{1} & Jordão Homem & & $1542 ?$ & & \\
\hline & da Costa* & $\begin{array}{l}\text { Jordão Homem } \\
\text { da Costa }\end{array}$ & 1620 & Tab. Orf & $\begin{array}{l}\text { ACRJ- } \\
\text { ECV,1668 }\end{array}$ \\
\hline \multirow[t]{2}{*}{2} & Aleixo Manuel & & 1572 & Cap.Inf. & \\
\hline & & $\begin{array}{l}\text { Ant. Muniz } \\
\text { de Menezes }\end{array}$ & 1665 & Cap.Inf. & $\begin{array}{l}\text { ACRJ- } \\
\text { ECV }, 1662\end{array}$ \\
\hline \multirow[t]{2}{*}{2} & Domingos Machado & & 1575 & & \\
\hline & & $\begin{array}{l}\text { Luis Machado } \\
\text { Homem }\end{array}$ & 1646 & J.Orfãos & $\begin{array}{l}\text { ACRJ- } \\
\mathrm{EH}, 1674\end{array}$ \\
\hline \multirow[t]{2}{*}{2} & Luís Barcelos & & 1607 & & \\
\hline & & $\begin{array}{l}\text { Manuel Barcelos } \\
\text { Machado }\end{array}$ & 1646 & & $\begin{array}{l}\text { ACRJ- } \\
\text { ECV,1662 }\end{array}$ \\
\hline
\end{tabular}




\begin{tabular}{|c|c|c|c|c|c|}
\hline 2 & $\begin{array}{l}\text { Manuel de Azedias } \\
\text { Valadão }\end{array}$ & & 1611 & & \\
\hline & & $\begin{array}{l}\text { Manuel Azedias } \\
\text { Valadão }\end{array}$ & 1666 & & $\begin{array}{l}\text { ACRJ- } \\
\text { EQ,1686 }\end{array}$ \\
\hline 2 & $\begin{array}{l}\text { Jorge Fernandes } \\
\text { da Fonseca }\end{array}$ & $\begin{array}{l}\text { Jorge Fernandes } \\
\text { da Fonseca }\end{array}$ & 1615 & & $\begin{array}{l}\text { Rio de Ja- } \\
\text { neiro (1935) }\end{array}$ \\
\hline 2 & Jo. do Zouro de Oliv. & $\begin{array}{l}\text { Jo. do Zouro } \\
\text { de Oliv. }\end{array}$ & 1616 & & $\begin{array}{l}\text { ACRJ- } \\
\mathrm{EH}, 1689\end{array}$ \\
\hline 2 & Pedro de Oliveira & Pedro de Oliveira & 1622 & & $\begin{array}{l}\text { ACRJ- } \\
\text { ECV,1635 }\end{array}$ \\
\hline 2 & $\begin{array}{l}\text { Gaspar Carrilho } \\
\text { de Mattos }\end{array}$ & $\begin{array}{l}\text { Gaspar Carrilho } \\
\text { de Mattos }\end{array}$ & 1634 & Tabelião & $\begin{array}{l}\text { ACRJ- } \\
\text { ECV,1662 }\end{array}$ \\
\hline 2 & $\begin{array}{l}\text { Franc. de Araujo } \\
\text { Caldeira }\end{array}$ & $\begin{array}{l}\text { Franc. de Araujo } \\
\text { Caldeira }\end{array}$ & 1640 & & $\begin{array}{l}\text { Araujo } \\
(1901)\end{array}$ \\
\hline 2 & $\begin{array}{l}\text { Fernando Cabral } \\
\text { de Melo }\end{array}$ & $\begin{array}{l}\text { Fernando Cabral } \\
\text { de Melo }\end{array}$ & 1642 & & $\begin{array}{l}\text { ACRJ- } \\
\text { ECV,1689 }\end{array}$ \\
\hline 2 & $\begin{array}{l}\text { Amador Lemos } \\
\text { Ferreira }\end{array}$ & $\begin{array}{l}\text { Amador Lemos } \\
\text { Ferreira }\end{array}$ & 1673 & & $\begin{array}{l}\text { ACRJ- } \\
\mathrm{EH}, 1692\end{array}$ \\
\hline 2 & $\begin{array}{l}\text { Manuel da Guarda } \\
\text { Muniz }\end{array}$ & $\begin{array}{l}\text { Manuel da Guarda } \\
\text { Muniz }\end{array}$ & 1649 & & $\begin{array}{l}\text { ACRJ- } \\
\text { EFI,1685 }\end{array}$ \\
\hline 2 & Aleixo Vaz & Aleixo Vaz & 1674 & & $\begin{array}{l}\text { ACRJ- } \\
\text { EFi,1668 }\end{array}$ \\
\hline 1 & $\begin{array}{l}\text { Franc. Lemos } \\
\text { de Azevedo }\end{array}$ & $\begin{array}{l}\text { Franc. Lemos } \\
\text { de Azevedo }\end{array}$ & 1597 & Alcaide & $\begin{array}{l}\text { ACRJ- } \\
\text { AR,1635 }\end{array}$ \\
\hline 2 & $\begin{array}{l}\text { Luiz Reinoso } \\
\text { Queixada }\end{array}$ & $\begin{array}{l}\text { Luiz Reinoso } \\
\text { Queixada }\end{array}$ & 1648 & & $\begin{array}{l}\text { ACRJ- } \\
\text { EQ,1662 }\end{array}$ \\
\hline 1 & $\begin{array}{l}\text { Jerônimo Barbalho } \\
\text { Bezerra }\end{array}$ & & 1614 & Gov. & \\
\hline & $\begin{array}{l}\text { Agos.Barbalho } \\
\text { Bezerra }\end{array}$ & $\begin{array}{l}\text { Agos. Barbalho } \\
\text { Bezerra }\end{array}$ & ? & Gov. & $\begin{array}{l}\text { ACRJ- } \\
\text { ECV,1659 }\end{array}$ \\
\hline 2 & $\begin{array}{l}\text { Antonio da Costa } \\
\text { Ramires }\end{array}$ & & 1619 & & \\
\hline & & $\begin{array}{l}\text { Pedro da Costa } \\
\text { Ramires }\end{array}$ & 1668 & & $\begin{array}{l}\text { ACRJ- } \\
\text { EP,1663 }\end{array}$ \\
\hline 1 & $\begin{array}{l}\text { Gaspar Pereira } \\
\text { Carvalho }\end{array}$ & $\begin{array}{l}\text { Gaspar Pereira } \\
\text { Carvalho }\end{array}$ & $1614 ?$ & & $\begin{array}{l}\text { Reingantz, } \\
(1965)\end{array}$ \\
\hline 2 & Franc. de Lemos Faria & $\begin{array}{l}\text { Luis de Lemos } \\
\text { Pereira }\end{array}$ & 1644 & & $\begin{array}{l}\text { Reingantz } \\
\text { (1965) }\end{array}$ \\
\hline
\end{tabular}




\begin{tabular}{|c|c|c|c|c|c|}
\hline 1 & Diogo de Amorim & Diogo de Amorim & $1573 ?$ & & Reingantz, \\
\hline & Soares & Soares & & & $(1965)$ \\
\hline 2 & Seb. Fagundes Varela & $\begin{array}{l}\text { Seb. Fagundes } \\
\text { Varela }\end{array}$ & 1613 & & $\begin{array}{l}\text { Belchior } \\
(1965)\end{array}$ \\
\hline 2 & João Fagundes Paris & João Fagundes Paris & 1635 & & $\begin{array}{l}\text { ACRJ- } \\
\text { EP, } 1650\end{array}$ \\
\hline 1 & Manuel da Costa & Manuel da Costa & $1605 ?$ & & $\begin{array}{l}\text { ACRJ- } \\
\text { Dote, } 1635\end{array}$ \\
\hline 2 & Franc. Barbosa Caldas & $\begin{array}{l}\text { Franc. Barbosa } \\
\text { Caldas }\end{array}$ & 1635 & & $\begin{array}{l}\text { ACRJ- } \\
\text { Dote, } 1635\end{array}$ \\
\hline 1 & Manuel de Castilho & & 1595 & Alm. & \\
\hline 2 & $\begin{array}{l}\text { Manuel Caldeira } \\
\text { Soares }\end{array}$ & $\begin{array}{l}\text { João de Castilho } \\
\text { Pinto } \\
\text { Manuel Caldeira } \\
\text { Soares }\end{array}$ & $\begin{array}{l}1617 \\
1651\end{array}$ & Cap.Fort & $\begin{array}{l}\text { ACRJ- } \\
\text { ECV,1668 } \\
\text { ACRJ- } \\
\text { ECV,1674 }\end{array}$ \\
\hline 1 & Miguel Gomes Bravo & $\begin{array}{l}\text { Miguel Gomes } \\
\text { Bravo }\end{array}$ & 1593 & Tes.Def. & ACRJ-Dote \\
\hline 2 & $\begin{array}{l}\text { João do Couto } \\
\text { Carnide }\end{array}$ & $\begin{array}{l}\text { João do Couto } \\
\text { Carnide }\end{array}$ & 1624 & & $\begin{array}{l}\text { ACRJ- } \\
\text { ECV,1632 }\end{array}$ \\
\hline 2 & Pant. Duarte Velho & Pant. Duarte Velho & 1637 & & $\begin{array}{l}\text { ACRJ- } \\
E Q, 1674\end{array}$ \\
\hline 2 & Manuel de Gouveia & Manuel de Gouveia & 1645 & & $\begin{array}{l}\text { ACRJ- } \\
\text { EH,1662 }\end{array}$ \\
\hline 1 & Julião Rangel de Abreu & & 1574 & Ouvidor & \\
\hline 2 & Balthazar de Abreu & $\begin{array}{l}\text { Pedro de Abreu } \\
\text { Rangel }\end{array}$ & $\begin{array}{l}1613 \\
1641\end{array}$ & & $\begin{array}{l}\text { ACRJ- } \\
\text { ECV,1664 }\end{array}$ \\
\hline 2 & $\begin{array}{l}\text { Gaspar Mariz } \\
\text { de Almeida }\end{array}$ & $\begin{array}{l}\text { Gaspar Mariz } \\
\text { de Almeida }\end{array}$ & 1650 & Capmor & $\begin{array}{l}\text { ACRJ- } \\
E Q, 1671\end{array}$ \\
\hline 1 & Domingos Muro & Gonçalo Muro & $\begin{array}{l}1598 \\
1629\end{array}$ & & $\begin{array}{l}\text { ACRJ- } \\
\text { EH,1654? }\end{array}$ \\
\hline 2 & $\begin{array}{l}\text { Bento da Rocha } \\
\text { Gondim }\end{array}$ & $\begin{array}{l}\text { Bento da Rocha } \\
\text { Gondim }\end{array}$ & 1656 & & $\begin{array}{l}\text { ACRJ- } \\
E Q, 1679\end{array}$ \\
\hline 1 & Manuel Veloso Doria & $\begin{array}{l}\text { Manuel Veloso } \\
\text { Doria }\end{array}$ & $1603 ?$ & & $\begin{array}{l}\text { Belchior } \\
(1965)\end{array}$ \\
\hline 2 & $\begin{array}{l}\text { Luiz V. M. } \\
\text { Soutomaior }\end{array}$ & $\begin{array}{l}\text { Luiz V. M. } \\
\text { Soutomaior }\end{array}$ & 1655 & & $\begin{array}{l}\text { IHGB } \\
(1943)\end{array}$ \\
\hline 1 & Antonio de Mariz & & 1567 & Prov.Faz & \\
\hline
\end{tabular}




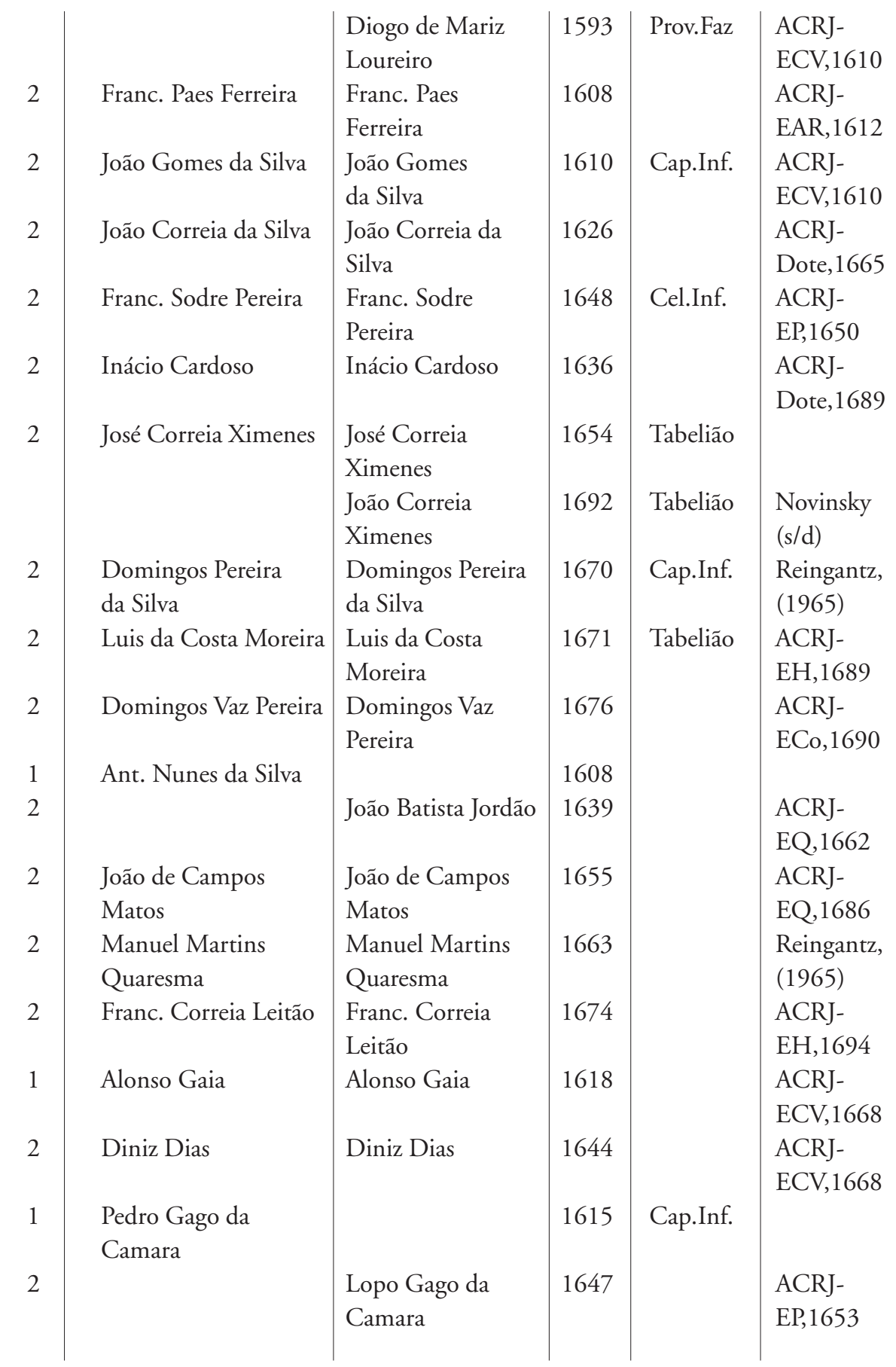




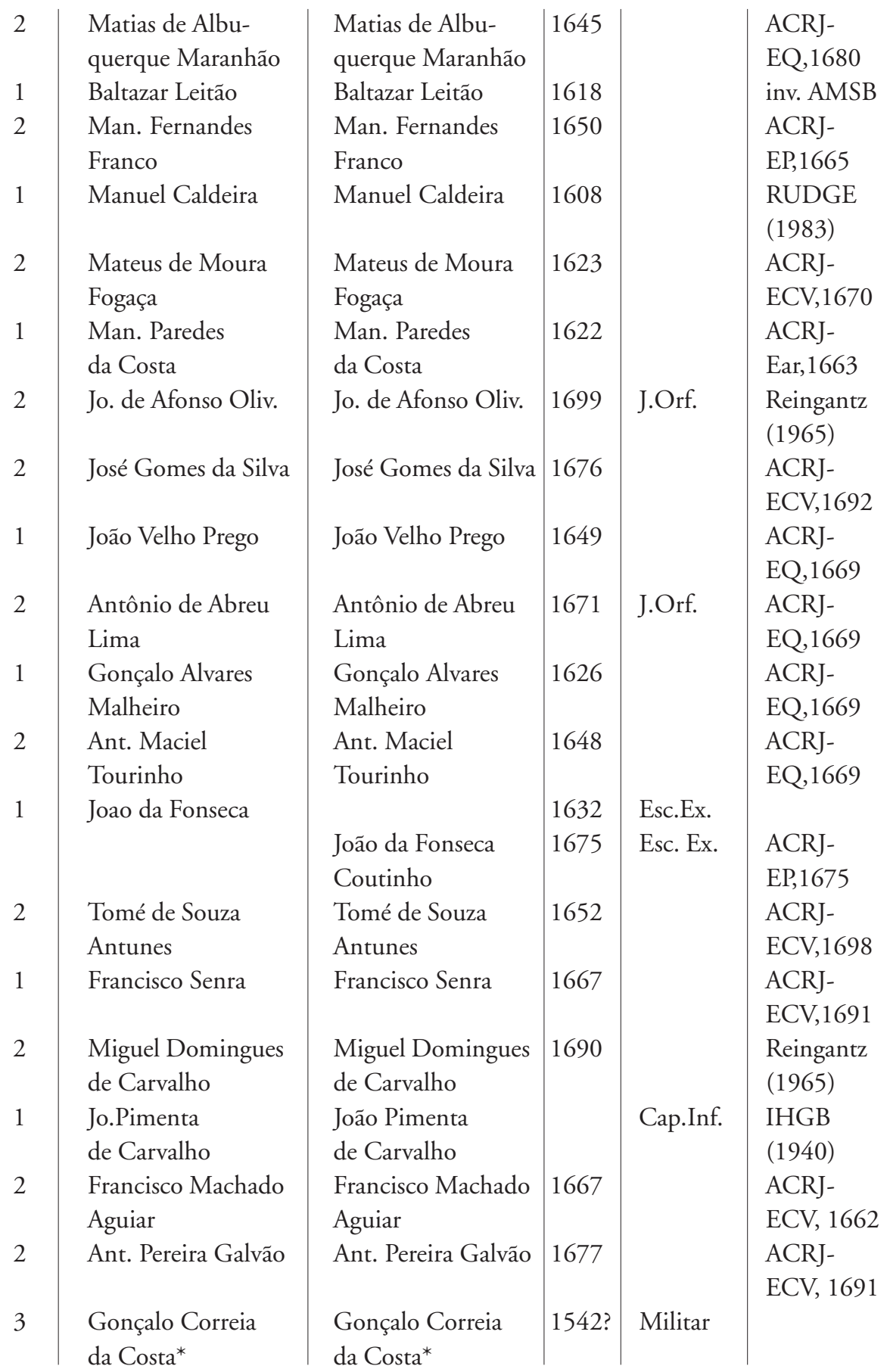




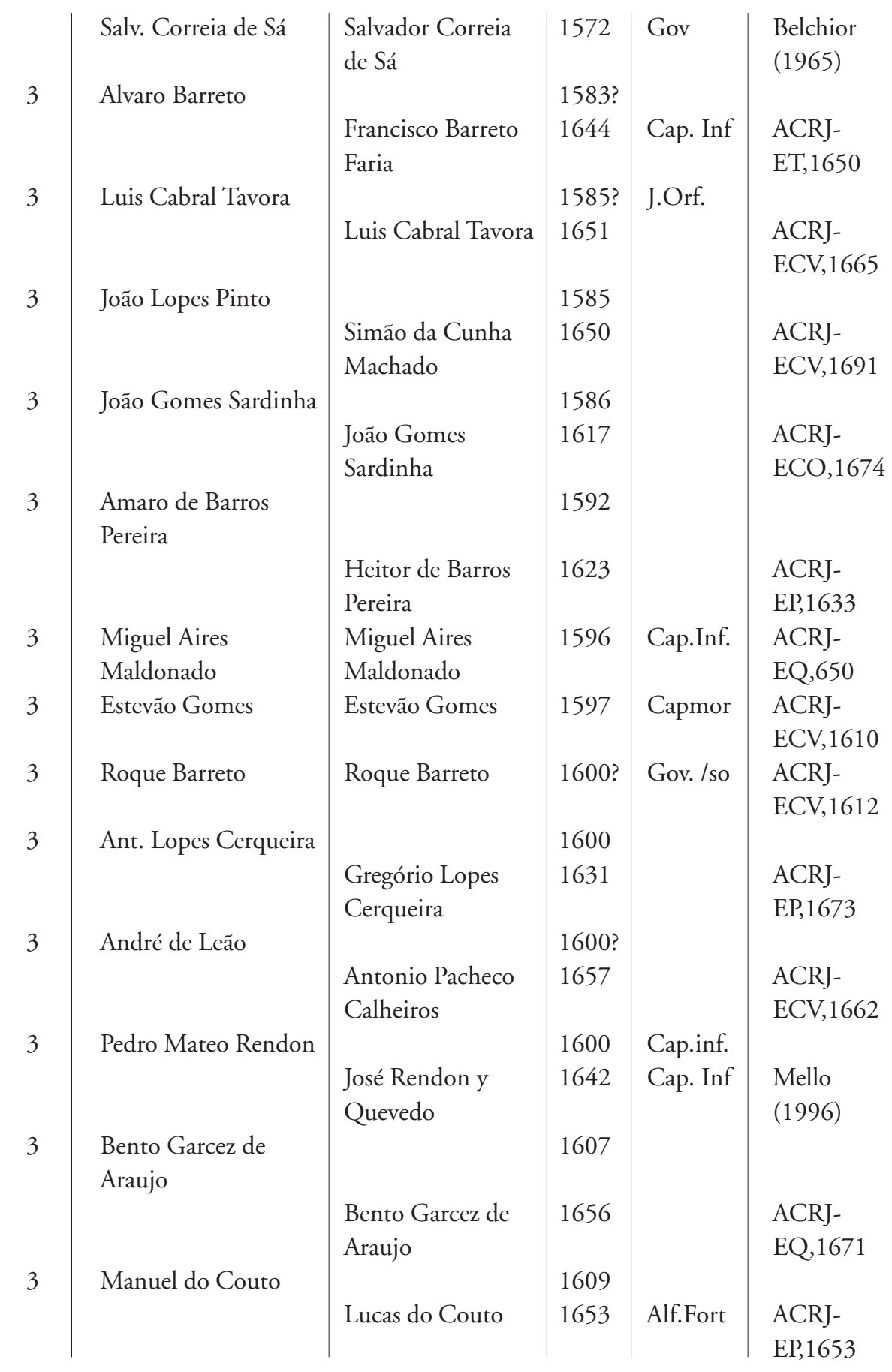




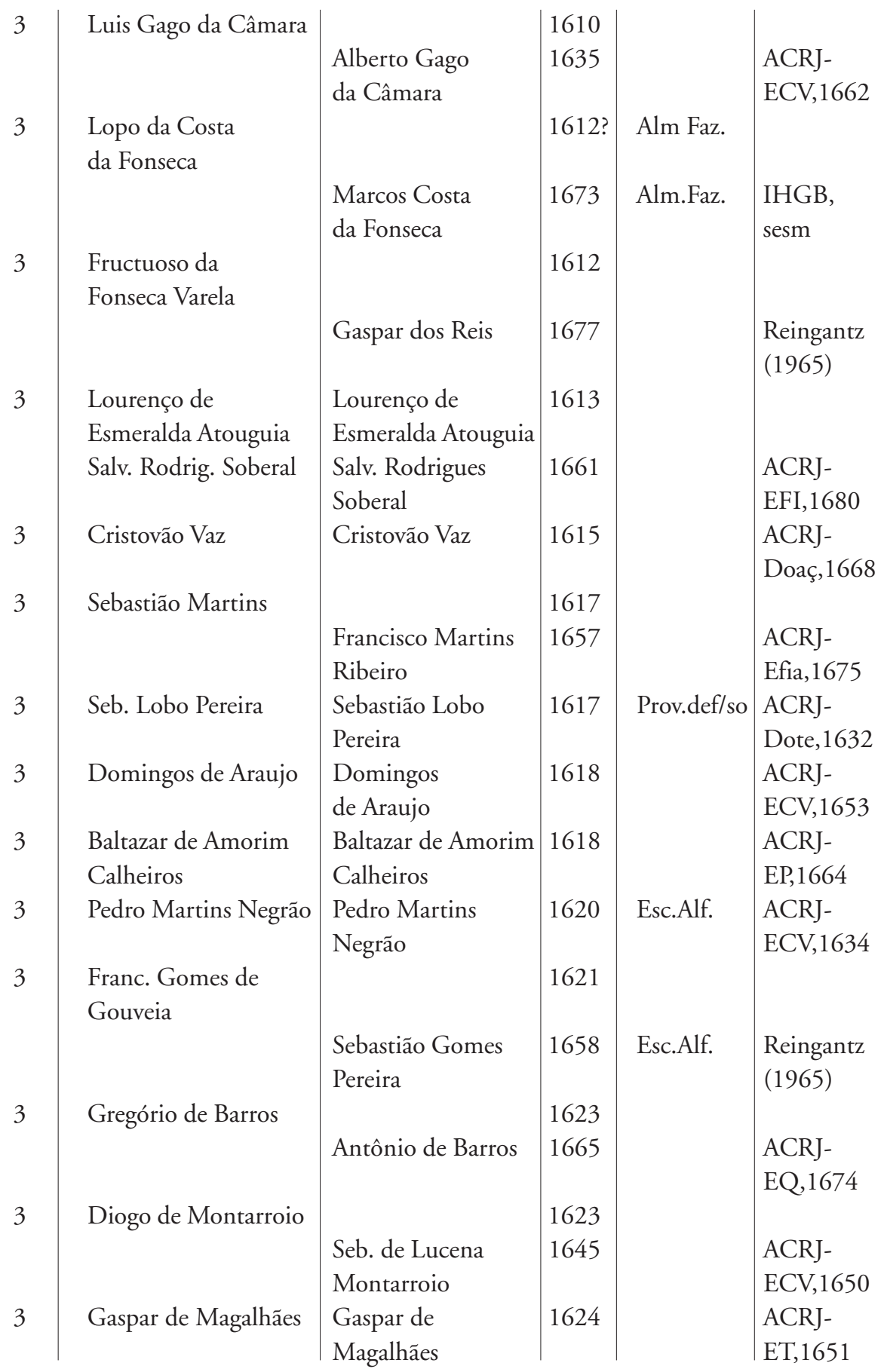




\begin{tabular}{|c|c|c|c|c|c|}
\hline 3 & $\begin{array}{l}\text { Feliciano Coelho } \\
\text { Cam }\end{array}$ & $\begin{array}{l}\text { Feliciano } \\
\text { Coelho Cam }\end{array}$ & 1624 & & $\begin{array}{l}\text { Araujo } \\
(1901)\end{array}$ \\
\hline 3 & $\begin{array}{l}\text { Luiz de Freitas } \\
\text { Matoso }\end{array}$ & $\begin{array}{l}\text { Luiz de Freitas } \\
\text { Matoso }\end{array}$ & 1626 & Cap.Inf. & $\begin{array}{l}\text { Araujo } \\
(1901)\end{array}$ \\
\hline 3 & João Alvares Pereira & João Alvares Pereira & 1626 & & $\begin{array}{l}\text { ACRJ- } \\
\text { ECV,1650 }\end{array}$ \\
\hline 3 & $\begin{array}{l}\text { Domingos Gomes } \\
\text { Pereira }\end{array}$ & $\begin{array}{l}\text { Domingos Gomes } \\
\text { Pereira }\end{array}$ & 1627 & & $\begin{array}{l}\text { ACRJ- } \\
\mathrm{EH}, 1674\end{array}$ \\
\hline 3 & João Luis Mafra & João Luis Mafra & 1632 & Sarmor & $\begin{array}{l}\text { ACRJ- } \\
\text { ECV,1633 }\end{array}$ \\
\hline 3 & $\begin{array}{l}\text { MateusCorreia } \\
\text { Pestana }\end{array}$ & $\begin{array}{l}\text { MateusCorreia } \\
\text { Pestana }\end{array}$ & 1633 & & $\begin{array}{l}\text { ACRJ- } \\
\text { EQ,1673 }\end{array}$ \\
\hline 3 & Antonio Dias & Antonio Dias & 1636 & & $\begin{array}{l}\text { ACRJ- } \\
\text { EP, } 1650\end{array}$ \\
\hline 3 & Bento Pinheiro & Bento Pinheiro & 1636 & & $\begin{array}{l}\text { ACRJ- } \\
\text { EP, } 1653\end{array}$ \\
\hline 3 & $\begin{array}{l}\text { Gonçalo Pontes } \\
\text { Labrit }\end{array}$ & $\begin{array}{l}\text { Gonçalo Pontes } \\
\text { Labrit }\end{array}$ & 1636 & & $\begin{array}{l}\text { ACRJ- } \\
\text { ECV,1662 }\end{array}$ \\
\hline 3 & João Dias Rangel & João Dias Rangel & 1637 & & $\begin{array}{l}\text { ACRJ- } \\
E C V, 1691\end{array}$ \\
\hline 3 & Antônio Ribeiro & $\begin{array}{l}\text { Antônio Ribeiro } \\
\text { Afo. Gonçalves } \\
\text { de Azevedo }\end{array}$ & $\begin{array}{l}1638 ? \\
1638\end{array}$ & Tabel. & $\begin{array}{l}\text { ACRJ- } \\
\text { ECV, } 1650 \\
\text { ACRJ- } \\
\text { EFI,1663 }\end{array}$ \\
\hline 3 & Domingos Casado & Domingos Casado & 1641 & & $\begin{array}{l}\text { ACRJ- } \\
\text { ECV,1662 }\end{array}$ \\
\hline 3 & Roque de Gouveia & Roque de Gouveia & 1641 & & $\begin{array}{l}\text { ACRJ- } \\
\text { PRO,1662 }\end{array}$ \\
\hline 3 & Diogo Pacheco & Diogo Pacheco & 1644 & & $\begin{array}{l}\text { ACRJ- } \\
\text { Test., } 1658\end{array}$ \\
\hline 3 & João Godinho & $\begin{array}{l}\text { João Godinho } \\
\text { Rosado1 }\end{array}$ & $\begin{array}{l}1644 \\
1675\end{array}$ & & $\begin{array}{l}\text { Araujo } \\
(1901)\end{array}$ \\
\hline 3 & $\begin{array}{l}\text { Franc. Frazão } \\
\text { de Souza* }\end{array}$ & & $1620 ?$ & & \\
\hline 3 & Inácio de Andrade & $\begin{array}{l}\text { Pedro de Souza } \\
\text { Pereira } \\
\text { Inácio de Andrade }\end{array}$ & 1645 & Prov.Faz & $\begin{array}{l}\text { Inventário, } \\
\text { MSB } \\
\text { ACRJ- } \\
\text { ECV,1670 }\end{array}$ \\
\hline
\end{tabular}




\begin{tabular}{|c|c|c|c|c|c|}
\hline \multirow[t]{3}{*}{3} & \multirow[t]{3}{*}{ Francisco Mateus } & \multirow{6}{*}{$\begin{array}{l}\text { Antonio da } \\
\text { Fonseca Diniz } \\
\text { Jorge de Souza } \\
\text { Coutinho }\end{array}$} & \multirow{2}{*}{\multicolumn{2}{|c|}{$\begin{array}{l}1645 \\
1694\end{array}$}} & \multirow{6}{*}{$\begin{array}{l}\text { ACRJ- } \\
\text { EH,1693 } \\
\text { IHGB,t. } \\
95, \text { v. } 149\end{array}$} \\
\hline & & & & & \\
\hline & & & & & \\
\hline \multirow[t]{2}{*}{3} & Jorge de Souza & & $1645 ?$ & Esc. & \\
\hline & Coutinho & & & & \\
\hline \multirow[t]{2}{*}{3} & $\begin{array}{l}\text { Franc. Pacheco } \\
\text { de Azevedo }\end{array}$ & & $1645 ?$ & & \\
\hline & & $\begin{array}{l}\text { José Pacheco } \\
\text { de Azevedo }\end{array}$ & 1675 & Escr. & $\begin{array}{l}\text { ACRJ- } \\
\text { Efia, } 1694\end{array}$ \\
\hline & Tomé da Silva & Tomé da Silva & $1646 ?$ & & $\begin{array}{l}\text { RUDGE } \\
(1983)\end{array}$ \\
\hline 3 & $\begin{array}{l}\text { Franc. Fernandes } \\
\text { de Azevedo }\end{array}$ & $\begin{array}{l}\text { Franc. Fernandes } \\
\text { de Azevedo }\end{array}$ & 1648 & & $\begin{array}{l}\text { ACRJ- } \\
\text { PRO,1674 }\end{array}$ \\
\hline 3 & Manuel Vaz Coelho & $\begin{array}{l}\text { Manuel Vaz } \\
\text { Coelho }\end{array}$ & 1648 & & $\begin{array}{l}\text { ACRJ- } \\
\text { ECo, } 1697\end{array}$ \\
\hline 3 & Jacinto Lobo Pereira & $\begin{array}{l}\text { Jacinto Lobo } \\
\text { Pereira }\end{array}$ & 1649 & & $\begin{array}{l}\text { ACRJ- } \\
\text { ECV,1691 }\end{array}$ \\
\hline 3 & Manuel Francisco & Manuel Francisco & $1650 ?$ & & $\begin{array}{l}\text { ACRJ- } \\
\text { ECV,1662 }\end{array}$ \\
\hline 3 & João Gago de Oliveira & $\begin{array}{l}\text { João Gago } \\
\text { de Oliveira }\end{array}$ & 1650 & & $\begin{array}{l}\text { ACRJ- } \\
\mathrm{EH}, 1694\end{array}$ \\
\hline 3 & João Lopes Lago & João Lopes Lago & 1652 & Alm. & $\begin{array}{l}\text { ACRJ- } \\
\mathrm{ECV}, 1650\end{array}$ \\
\hline 3 & $\begin{array}{l}\text { Ant. Zuzarte } \\
\text { de Almeida }\end{array}$ & $\begin{array}{l}\text { Ant. Zuzarte } \\
\text { de Almeida }\end{array}$ & 1652 & & $\begin{array}{l}\text { ACRJ- } \\
\mathrm{EH}, 1672\end{array}$ \\
\hline \multirow[t]{2}{*}{3} & $\begin{array}{l}\text { Luis Lopes de } \\
\text { Carvalho }\end{array}$ & & 1653 & Tabel. & \\
\hline & & $\begin{array}{l}\text { Miguel Lopes de } \\
\text { Carvalho }\end{array}$ & 1679 & & $\begin{array}{l}\text { ACRJ- } \\
\mathrm{EH}, 1689\end{array}$ \\
\hline 3 & João Lopes Experto & João Lopes Experto & 1654 & & $\begin{array}{l}\text { ACRJ- } \\
\mathrm{EH}, 1679\end{array}$ \\
\hline 3 & Francisco Gomes & Francisco Gomes & 1656 & & $\begin{array}{l}\text { ACRJ- } \\
\text { ECV }, 1650\end{array}$ \\
\hline & $\begin{array}{l}\text { Salv. Fernandes } \\
\text { de Aguiar }\end{array}$ & $\begin{array}{l}\text { Salvador Fernandes } \\
\text { de Aguiar }\end{array}$ & 1658 & & $\begin{array}{l}\text { ACRJ- } \\
\text { ECV,1692 }\end{array}$ \\
\hline & Manuel Toledo Royas & Manuel Toledo & 1659 & & ACRJ- \\
\hline & Fernando da Gama & $\begin{array}{l}\text { Royas } \\
\text { Fernando da Gama }\end{array}$ & $1660 ?$ & Capmor. & $\begin{array}{l}\text { EQ,1692 } \\
\text { ACRJ- } \\
\text { EQ,1694 }\end{array}$ \\
\hline
\end{tabular}




\begin{tabular}{|c|c|c|c|c|c|}
\hline 3 & Manuel de Azevedo & Manuel de Azevedo & 1660 & & $\begin{array}{l}\text { ACRJ- } \\
\text { FCV } 1697\end{array}$ \\
\hline & $\begin{array}{l}\text { Gaspar Pereira } \\
\text { de Oliveira }\end{array}$ & $\begin{array}{l}\text { Gaspar Pereira } \\
\text { de Oliveira }\end{array}$ & $1661 ?$ & & $\begin{array}{l}\text { ACRJ- } \\
\text { EP, } 1653\end{array}$ \\
\hline & Franc. Moura Fogaça & $\begin{array}{l}\text { Francisco Moura } \\
\text { Fogaça }\end{array}$ & 1662 & & $\begin{array}{l}\text { Reingantz } \\
(1965)\end{array}$ \\
\hline & $\begin{array}{l}\text { Pedro Albernaz } \\
\text { Correia }\end{array}$ & $\begin{array}{l}\text { Pedro Albernaz } \\
\text { Correia }\end{array}$ & 1663 & & $\begin{array}{l}\text { ACRJ-ET, } \\
1675\end{array}$ \\
\hline & $\begin{array}{l}\text { Manuel Cardoso } \\
\text { Leitão }\end{array}$ & $\begin{array}{l}\text { Manuel Cardoso } \\
\text { Leitão }\end{array}$ & 1663 & Tabel. & $\begin{array}{l}\text { AHU-RJ, } \\
692\end{array}$ \\
\hline & Franc. Dias Medonho & $\begin{array}{l}\text { Francisco Dias } \\
\text { Medonho }\end{array}$ & 1664 & & $\begin{array}{l}\text { ACRJ- } \\
\text { ECV,1694 }\end{array}$ \\
\hline 3 & $\begin{array}{l}\text { Franc. Correia } \\
\text { Drumond }\end{array}$ & $\begin{array}{l}\text { Francisco Correia } \\
\text { Drumond }\end{array}$ & 1666 & & $\begin{array}{l}\text { ACRJ- } \\
\text { ECV,1698 }\end{array}$ \\
\hline 3 & João Morato Ravasco & $\begin{array}{l}\text { João Morato } \\
\text { Ravasco }\end{array}$ & 1667 & & $\begin{array}{l}\text { ACRJ- } \\
\text { EP,1662 }\end{array}$ \\
\hline 3 & $\begin{array}{l}\text { Manuel Barcelos } \\
\text { Domingues }\end{array}$ & $\begin{array}{l}\text { Manuel Barcelos } \\
\text { Domingues }\end{array}$ & $1667 ?$ & & $\begin{array}{l}\text { ACRJ- } \\
E Q, 1680\end{array}$ \\
\hline & $\begin{array}{l}\text { Andre Fernandes } \\
\text { Brandão }\end{array}$ & $\begin{array}{l}\text { Andre Fernandes } \\
\text { Brandão }\end{array}$ & 1667 & & $\begin{array}{l}\text { ACRJ- } \\
\text { ECV,1679 }\end{array}$ \\
\hline 3 & $\begin{array}{l}\text { Franc. da Costa } \\
\text { Moura }\end{array}$ & $\begin{array}{l}\text { Francisco da Costa } \\
\text { Moura }\end{array}$ & 1668 & Tab.Orf. & $\begin{array}{l}\text { ACRJ- } \\
E Q, 1692\end{array}$ \\
\hline 3 & $\begin{array}{l}\text { Manuel Correia } \\
\text { Cabral }\end{array}$ & $\begin{array}{l}\text { Manuel Correia } \\
\text { Cabral }\end{array}$ & 1669 & Esc. & $\begin{array}{l}\text { ACRJ- } \\
\text { ECV,1696 }\end{array}$ \\
\hline 3 & João Dique & João Dique & 1672 & & $\begin{array}{l}\text { ACRJ- } \\
\mathrm{EH}, 1689\end{array}$ \\
\hline 3 & Francisco Vaz Garcez & $\begin{array}{l}\text { Francisco Vaz } \\
\text { Garcez }\end{array}$ & 1673 & & $\begin{array}{l}\text { ACRJ- } \\
\text { ECV,1685 }\end{array}$ \\
\hline 3 & Manuel Barbosa Lima & $\begin{array}{l}\text { Manuel Barbosa } \\
\text { Lima }\end{array}$ & 1676 & & $\begin{array}{l}\text { ACRJ- } \\
\text { ECV }, 690\end{array}$ \\
\hline 3 & $\begin{array}{l}\text { Gonç. da Costa } \\
\text { Ramos }\end{array}$ & $\begin{array}{l}\text { Gonçalo da Costa } \\
\text { Ramos }\end{array}$ & 1677 & & $\begin{array}{l}\text { Reingantz } \\
(1965)\end{array}$ \\
\hline 3 & $\begin{array}{l}\text { Antonio Borges } \\
\text { Madeira }\end{array}$ & $\begin{array}{l}\text { Antonio Borges } \\
\text { Madeira }\end{array}$ & 1678 & & $\begin{array}{l}\text { ACRJ- } \\
\mathrm{EH}, 1697\end{array}$ \\
\hline 3 & $\begin{array}{l}\text { Dionisio Correia } \\
\text { de Brito }\end{array}$ & $\begin{array}{l}\text { Dionisio Correia } \\
\text { de Brito }\end{array}$ & 1678 & & $\begin{array}{l}\text { ACRJ- } \\
\text { ECV,1679 }\end{array}$ \\
\hline 3 & $\begin{array}{l}\text { Domingos Coelho } \\
\text { de Souza }\end{array}$ & $\begin{array}{l}\text { Domingos Coelho } \\
\text { de Souza }\end{array}$ & 1680 & & $\begin{array}{l}\text { ACRJ- } \\
\text { ECV,1694 }\end{array}$ \\
\hline 3 & Franc. Gomes Ribeiro & $\begin{array}{l}\text { Francisco Gomes } \\
\text { Ribeiro }\end{array}$ & 1680 & Cap.Inf. & $\begin{array}{l}\text { ACRJ- } \\
\text { EPer,1689 }\end{array}$ \\
\hline
\end{tabular}


A Nobreza da RePÚblCA $\bullet 115$

\begin{tabular}{|c|c|c|c|c|c|}
\hline 3 & Pedro Sanches & Pedro Sanches & 1681 & & ACRJ-EP, \\
\hline & da Fonseca & da Fonseca & & & 1653 \\
\hline 3 & $\begin{array}{l}\text { Franc. de Almeida } \\
\text { Jordão }\end{array}$ & $\begin{array}{l}\text { Francisco de } \\
\text { Almeida Jordão }\end{array}$ & 1683 & Alm.faz. & $\begin{array}{l}\text { ACRJ- } \\
\text { ECV,1696 }\end{array}$ \\
\hline 3 & $\begin{array}{l}\text { Cristov de } \\
\text { Almeida Gamboa }\end{array}$ & $\begin{array}{l}\text { Christovão de } \\
\text { Almeida Gamboa }\end{array}$ & 1684 & Alf. Mar & $\begin{array}{l}\text { ACRJ- } \\
\text { EP,1689 }\end{array}$ \\
\hline 3 & Jeronimo de Medeiros & $\begin{array}{l}\text { Jeronimo de } \\
\text { Medeiros }\end{array}$ & 1684 & & $\begin{array}{l}\text { ACRJ- } \\
\text { ECV,1691 }\end{array}$ \\
\hline 3 & Ant. Correia Barbosa & $\begin{array}{l}\text { Antonio Correia } \\
\text { Barbosa }\end{array}$ & 1692 & & $\begin{array}{l}\text { ACRJ- } \\
\text { ECV,1692 }\end{array}$ \\
\hline
\end{tabular}

Obs: Tipo = Tipo de família senhorial: 1 = familia senhorial extensa; 2 = família senhorial devida por linha feminina derivada das extensas; 3 = família senhorial simples. Jo. = João; Franc. = Francisco; Oliv. $=$ Oliveira $;$ Crsit $=$ Cristovão $;$ Cust.$=$ Custódio $;$ Afo $=$ Afonso; Agos. = Agostinho; Seb. = Sebastião; Pant. = Pantaleão; Ant. = Antônio $;$ Man..$=$ Manuel; Salv. = Salvador; Rodrig. = Rodriguês; Gonç. $=$ Gonçalo; cap. inf. $=$ capitão de infantaria; alm = almoxarife da fazenda; alf. mar. = alferes de mar e guerra; tabel. = tabelião; esc. escrivão; j. orf. =juiz de orfãos; prov. faz. = provedor da fazenda; gov. governador; capmor = capitão mor; sarmor = sargento mor.

\section{Notas}

${ }^{1}$ Este artigo faz parte de uma pesquisa financiada pelo CNPq. Gostaria de agradecer o auxílio dos bolsistas de iniciação científica: Glacia Freitas de Oliveira, Vanusa de Oliveira Martins, Luiz Guilherme Scaldaferri Moreira e André Boucinhas

${ }^{2}$ FERLINI, Vera, Terra, Trabalho e Poder, São Paulo, Brasiliense, 1988, p. 60-61.

${ }^{3}$ SCHARTZ, Stuart. Segredos internos, São Paulo, Cia das Letras/CNPq, 1988, p.400.

${ }^{4}$ FERLINI, Vera, op. cit., pp.61-61.

${ }^{5}$ LISBOA, Balthazar. S., Anaes do Rio de Janeiro, t III, Rio de Janeiro, Typ. de seignotPlancher e C., 1835, p. 295.

${ }^{6}$ REINGANTZ, Carlos, Primeiras Famílias do Rio de Janeiro. Rio de Janeiro: Livraria Brasiliana, 1965.

${ }^{7}$ Cf. LEWIN, Linda, Política e Parentela na Paraíba, Rio de Janeiro, Record: 1993.

${ }^{8}$ GODINHO, Vitorino, M, Ensaios II, Lisboa, Sá da Costa, 1978, 262-64

9 SUBRAHMANYAM, Sanjay, O império asiático português, 1500-1700, Lisboa, Difel, 1995, pp. 205-6; BETHENCOURT, Francisco \& CHAUDHURI, K. (dir.), História da Expanção Portuguesa, vol. 2, Lisboa, Círculo do Livro, 1998, p. 290

${ }^{10}$ GODINHO, Vitorino, op. cip., p. 25-27. 
${ }^{11}$ Cf. GODINHO, Vitorino, op. cip., p. 65-72. Existe uma vasta historiografia sobre os traços do Antigo Regime em Portugal e as suas ligaçōes com o ultramar. Além dos trabalhos de Godinho ver, entre outros estudos. MAGALHÃES, Joaquim. R (coord.), História de Portugal - no Alvorecer da Modernidade, Lisboa, Ed. Estampa, 1993, HESPANHA, Antônio. M. (coord.) História de Portugal — Antigo Regime, Lisboa, Ed. Estampa,1993 ${ }^{12}$ MAGALHÃES, Joaquim. R, "A fazenda”, in: MAGALHĀES, Joaquim. R (coord.), op. cit. 93-98.

${ }^{13}$ GODINHO, Vitorino M., Introdução a História Econômica, Lisboa, Horizonte, s/d, p. 171.

${ }^{14}$ RODRIGUES, Teresa, F, “As estruturas Populacionais”, in: MAGALHÃES, Joaquim, R, (coord.). op. cit., pp. 218-22.

${ }^{15}$ GODINHO, Vitorino, op. cip., 1978, p.273

16 SCHWARTZ, Stuart, "Brasil Colonial: Plantaciones y Periferia, 1580-1750" in: BETHELL, L.(org.), Historia de América Latina, vol. 3, México, Crítica, 1990.p.204.

${ }^{17}$ GODINHO, Vitorino, op. cip., 1978, p.273

${ }^{18}$ SALLES LOUREIRO, F. 1986. "A Alteração das Coordenadas da política de Expansão Portuguesa na segunda Metade do século XVI", in: Actas das Primeiras Jornadas de História Moderna, vol. I, Lisboa, Centro de História da Universidade de Lisboa, pp. 259 - 73

${ }^{19}$ DISNEY, Anthony, R. A Decadência do Império da Pimenta, Lisboa, Edições 70, 1981, 67. 69; GODINHO, Vitorino, op. cip., 1978, p. 69.

${ }^{20}$ RODRIGUES, Teresa, F, “As estruturas Populacionais”, in: MAGALHĀES, Joaquim, R. (coord.).op. cit., pp. 197-210.

${ }^{21}$ VIEIRA, Alberto, Portugal y las Islas del Atlántico, Madri, Mapfre, 1992, 133 -203

${ }^{22}$ MONTEIRO, John. M, Negros da Terra, São Paulo, Cia das Letras, 1994, 57 - 128.

${ }^{23}$ MAGALHÂES, Joaquim, R, Mobilidade e cristalização social in: MAGALHÃES, Joaquim, R, (coord.). op. cit., pp. 503-504; THOMAZ, Luís, De Ceuta a Timor, Lisboa, Difel, 1994, p. 154.

${ }^{24}$ PAES LEME, Pedro, T., A.., Nobiliarquia Paulistana Histórica e Genealógica, t. II, Belo Horizonte: Ed. Itatiaia; São Paulo: Ed. da USP, 1980, p. 231.

${ }^{25}$ NORONHA, Henrique, Nobiliario da Ilha da Madeira, Funchal, Biblioteca Nacional, p. 385.

${ }^{26}$ MATTOSO, J. 1993. "A socialidade", in: MATTOSO, J., (coord.). História de Portugal - A Monarquia Feudal, Lisboa, Ed. Estampa, 1993, p. 449.

${ }^{27}$ Cf Anexo 1 com FRANCO, Francisco, A, C., Dicionário de Bandeirantes e Sertanistas do Brasil, Belo Horizonte: Ed. Itatiaia; São Paulo: Ed. da USP, 1989.

${ }^{28}$ Furtado, C., Formação econômica do Brasil, São Paulo, Ed. Nacional, 1976, p.11; SCHWARTZ, Stuart, op. cit., 1988, p. 225

${ }^{29}$ CANABRAVA, Alice, P., O Comércio Português no rio da Prata (1580-1640), Belo Horizonte, Ed. Itatiaia, São Paulo, Ed. da USP, 1984; LOBO, E. L., História do Rio de 
Janeiro, vol. 1, Rio de Janeiro, IBMEC, 1975, p.50. SALVADOR, José G. Os CristãosNovos e o Comércio no Atlântico Meridional, São Paulo, MEC, Ed. Pioneira, 1978, 330351; MELLO, Carl. O Rio de Janeiro no Brasil Quinhentista, Rio de Janeiro, Giordano, 1996, pp. 185-202.

${ }^{30}$ SCHWARTZ, Stuart, op. cit., 1988, p.146.

${ }^{31}$ AHU, av, cx. 6, doc. 35

${ }^{32} \mathrm{AHU}$, av, cx. 3, doc. 122

${ }^{33} \mathrm{AHU}$, av, cx. 2, doc. 24

${ }^{34}$ AMSB, inventátios post mortem: Feliciana de Pina (1656) e Pedro de Soua Pereira (1673); NOVINSKY, Anita, Inquisição, Imprensa Nacional, s/d, p. 132

${ }^{35}$ FRAGOSO, João, Homens de grossa aventura: acumulação e hierarquia na praça mercantil do Rio de Janeiro (1790 - 1830), $2^{2}$ ed., Rio de Janeiro, Civilização Brasileira, 1998, pp.337-38. A pequena amostragem para a primeira metade do século XVII deve-se, além do pequeno contingente demográfico da cidade (provavelmente menos de 10.000 habitantes entre livres e escravos - ver FRAGOSO, João,"Hierarquias sociais e formas de acumulação no Rio de Janeiro, século XVII", Colonial Latin American Review, vol 6, \#2. 1997), ao fato de que os livros para os demais cartórios da cidade, presentes no Arquivo Nacional, não estarem à disposiçãao do público em função de seu estado de conservação. ${ }^{36}$ PEDREIRA, Jorge M. V., Os Homens de negócio da Praça de Lisboa de Pombal ao Vintismo (1755-1822), Lisboa: Universidade Nova de Lisboa (tese de doutorado), 1995, p.18.

${ }^{37}$ Considerei algumas famílias senhoriais como domicílios de ministros apesar de não descenderem de um casal fundador com este cargo. Isto só ocorreu nos casos em que a família, por várias gerações, é claramente formada de pessoas ligadas à administração real. Tal foi o caso da família de Belchior da Ponte, que teve entre seus parentes capitães de infantaria, juizes de órfăos e um desembargador ou ainda de Pedro de Souza Correia, que contou com três Provedores da Fazenda Real.

${ }^{38}$ Frei VICENTE SALVADOR, História do Brasil, Belo Horizonte, Ed. Itatiaia, São Paulo, Ed. da USP, 1982, p. 166.

${ }^{39}$ SALGADO, Graça (org.), Fiscais e Meirinhos Rio de Janeiro, Arquivo Nacional \& Nova Fronteira, 1985, p. 55.

${ }^{40}$ BELCHIOR, E.O., Conquistadores e Povoadores do Rio de Janeiro. Rio de Janeiro, Livraria Brasiliana editora, 1965, pp. 429-435; COARACY, V., O Rio de Janeiro no século XVII, Rio de Janeiro, ed. José Olympio, 1944, p. XXVI.

${ }^{41}$ BELCHIOR, op. cit., 326-27 e 368-69; AHU, ca, cx. 3, doc. 440-448.

${ }^{42}$ SALGADO, op. cit.

${ }^{43}$ BELCHIOR, op. cit., 312-15.

${ }^{44} \mathrm{AHU}$, av, cx. 3, doc. 84;

${ }^{45}$ ATT, Chancelaria de Filipe II, liv. 16, p. 209; BELCHIOR, op. cit., 312-15.

${ }^{46}$ AHU, ca, cx. 5, doc. 844; Ordenaçôes Filipinas 1985,, L. I, t. LXXXVIII. 
${ }^{47}$ BELCHIOR, op. cit.,440-41.

${ }^{48}$ Cf. LOCKHART, John, Spanish Peru, 1532-1560, Madson: Wisconsin Press, p. 1968, p. 11-33; ELLIOTT, John., "La conquista española y las colonias de América", in: Bethell, L. (org.),op. cit., vol. 1, pp. 155-169; PEÑA, J, Oligarquía y Propiedad en Nueva España, 1550-1624, México: Fundo de Cultura Económico, 1983, pp. 148-149.

${ }^{49}$ BELCHIOR, op. cit., p. 385-87; AHU, códice 115.

${ }^{50}$ Idem, Ibidem, 1965, 154-55

${ }^{51} \mathrm{Um}$ estudo pioneiro sobre as ligaçōes entre a burocracia e elites coloniais é o de SCHWARTZ, Stuart, Burocracia e Sociedade no Brasil Colonial. São Paulo, Ed. Perspectiva, 1979.

52 Ao que parece, o mesmo não ocorreria com os descendentes dos conquistadores espanhóis do México. Passado os tempos da conquista, aquele grupo seria substituído por outros segmentos sociais ver ELLIOT, J., Op. cit., p. 25.

53 BN, DH, v. 19, p. 464.

${ }^{54}$ AHU, ca, cx. 3, doc. 295. Desde 1639 há referência de Pedro ocupar o posto de provedor da fazenda (AHU, ca,cx2, doc229-231), contudo, a provisão real da propriedade. do ofício é datada de 1644

${ }^{55}$ Frei VICENTE SALVADOR, op. cit. pp.254-55

${ }^{56}$ SERRÃO, Joaquim, V., O Rio de Janeiro no século XVI, Lisboa, Comissão Nacional das Comemorações do IV Centenário do Rio de Janeiro, 1965, p. 115. Frei VICENTE SALVADOR, op. cit. p. 355

${ }^{57}$ MENDONÇA, Paulo. K., O Rio de Janeiro da Pacificação, Rio de Janeiro, Secretaria Municipal de Culltura, 1991, 104-5; (SCHWARTZ, op. cit., 1988, p. 46.

${ }^{58}$ BELCHIOR, E., op. cit., p.437-38; MENDONÇA, P., op. cit. p.102; AHU, av, cx. 1, doc. 24; AHU, av., cx. 1, doc. 25.

59 TEXEIRA da SILVA, Francisco C.,. Morfologia da Escassez, Niterói: Universidade Federal Fluminense, (tese de doutorado inédita), 1990, pp. 321-326..

${ }^{60}$ SOBRAL NETO, M. "A Persistência Senhorial”, in: Magalhães, J. R (coord.). op. cit., 1993 , p. 165

${ }^{61}$ GONÇALO MONTEIRO, Nuno, "Poder senhorial, estatuto nobiliárquico e aristocracia”, in: HESPANHA, A. M. (coord.), op. cit., 1993, pp. 333-370. Uma das maneiras de se entender as mercês distribuídas pelo rei é, talvez, utilizando a noção de "economia do dom” inspirada em Marcel Mauss. O movimento de dar pressupõe também receber e retribuir (MAUSS, Marcel, Sociologia e Antropologia, São Paulo: EPU.1974), e deste modo se estabelece relações sociais cuja marca é o desequilíbrio e a dependência. Portanto, para a Coroa, os privilégios concedidos permitiam o estabelecimento de vínculos de subordinação para com a aristocracia e, conseqüentemente, o fortalecimento da autoridade real. Para a aplicação deste conceito na analise do Antigo Regime português ver Xavier e HESPANHA (XAVIER, A. \& HESPANHA, A.,. "As redes de clientelares" in: HESPANHA, A. M. (coord.), op. cit. 1993, 382-386) 
${ }^{62}$ THOMAZ, Luís, op. cit., p. 430

${ }^{63}$ AHU, Angola, cx. 15, doc. 36.

${ }^{64}$ Cf. MAGALHĀES, Joaquim, R., op. cit.,1993, p. 487-507; SILVA, Maria, J., O., Fidalgos-mercadores no século XVIII, Lisboa: Imprensa Nacional, 1992; Rau, Virginia, "Fortunas ultramarinas e a nobreza portuguesa no século XVII", Estudos sobre a História econômica e social do Antigo Regime, Lisboa, Ed. Presença, 1984; GODINHO, Vitorino, A estrutura da antiga sociedade portuguesa, Lisboa, Arcádia, 1975

${ }^{65}$ BOXER, C. R., O império colonial português, Lisboa, Edições 70, 1981, p.285.

${ }^{66}$ CURTO, D. R. 1993. "A Formação dos Agentes”, in: Magalhães, J. R. (coord.), op. cit., 1993, p. 133; SUBRAHMAYAM, op. cit., p. 221; DISNEY, A, op. cit., p. 81.

${ }^{67}$ BURKHOLDER, M., "Burócratas", in: HOBERMAN, L. \& SOCOLOLOW, S., Cuidades y sociedad en latinoamérica colonial, México, Fundo de Cultura Económica, 1992, pp. 111-16.

${ }^{68}$ AHU, av, cx. 1, doc. 6.

${ }^{69}$ AHU, av, cx. 3, doc. 48

${ }^{70}$ BOXER, C., Salvador de Sá e a luta pelo Brasil e Angola, 1602-1686, São Paulo, Ed. Nacional, Ed. da Universidade de São Paulo, 1993, pp. 194-204.

${ }^{71}$ AHU, av, cx. 3, doc. 11.

72 (AHU, av, cx. 3, doc. 93)

${ }^{73}$ Esta realidade de "mercado imperfeito", ou de interferência da política na economia, como era de se esperar, não é estranha para a América espanhola. Entre outros autores ver: PEÑA, J., op. cit., BURKHOLDER, M, op. cit.

${ }^{74}$ AHU, ca, docs. 204, 971-72, 975-77 e 1915.

75 AGRJ, EP., 1697.

${ }^{76}$ HESPANHA, A,M., As vésperas do Leviathan, Coimbra, Liv. Almedina, 1994, pp. 161 224

${ }^{77}$ AHU, ca, doc. 268.

${ }^{78}$ AHU, av, cx.1, doc. 15.

${ }^{79}$ AHU, ca, doc. 268.

${ }^{80}$ BN, DH, vol. 16, p. 153; (AHU, av, cx. 1, doc. 41); AHU, av, cx. 1, doc. 8.

${ }^{81}$ AHU, av, cx. 1, doc. 41; REINGANTZ, op. cit., vol. 2, p.277; COARACY, op. cit., xxxvi)

${ }^{82}$ ATT, Chancelaria de Filipe III, Doações, liv. 32, p. 278v; AGRJ, EP., 1635, p. 79; AHU, av, cx. 1 , doc. 82

${ }^{83}$ AN, Pub. \# 11; AHU, ca, doc. 2215; (AN, EP., 1686, p. 20; AN, EP., 1698, p. 83)

${ }^{84}$ COUTO, Diogo, O Soldado Prático, Lisboa, Ediçōes Europa-América, s/d.

${ }^{85}$ AHU, av, cx. 2, doc. 57; AHU, av, cx. 1, doc. 47. 
${ }^{86}$ AHU, av, cx. 1, doc. 15.

${ }^{87}$ AHU, ca, doc. 229-231 e ca, doc. 1621-22; AHU, av, cx.3, doc. 95; AN, EP, cv., 1650; AHU, ca, doc. 1285-89); AN, EP, arr., 1673

${ }^{88}$ AHU, ca, doc. 2050.

${ }^{89}$ AHU, av, cx. 4, doc. 48

${ }^{90}$ AHU, av, cx. 2, doc. 57.

${ }^{91} \mathrm{AHU}$, av, cx. 4, doc. 107. Sobre o assunto, entre outros, ver: BRAUDEL, F, Os Jogos da Troca, Lisboa, Ed. Cosmos, 1985; POLANIY, Karl, A Grande Transformação, Rio de Janeiro, Ed. Campus, 1980; MAGALHĀES, Joaquim. R., O Algarve Econômico, 1600-1773, Lisboa, Estampa, 1988; GONÇALO MONTEIRO, "O espaço político e social local”, in: OLIVEIRA, C. (dir.), História dos Municípios e do Poder Local, Lisboa, Temas e Debates, 1996. Para um balanço historiográfico sobre a Câmara municipal na América portuguesa colonial ver: BICALHO, Maria, F., A Cidade e o Império: Rio de Janeiro na dinâmica Colonial Portuguesa. Séculos XVII e XVIII, São Paulo: USP (tese de doutoramento inédita), 1997; GOUVEA, Maria. F., "Redes de Poder na América Portuguesa. O Caso da Câmara do Rio de Janeiro em fins do século XVIII e Início do XIX”, in: O Município no Mundo Português — seminário internacional, Funchal: Centro de Estudos de História do Atlântico. Sobre um resumo da competência das Câmaras portuguesas, segundo as Ordenações Filipinas, no domínio econômico ver HESPANHA, op. cit.,1994, p. 161, nota 104.

92 RIO DE JANEIRO, Diretoria Geral do Patrimônio, Estatística e Arquivo, O Rio de Janeiro no séc. XVII - Acordóes e Veranças do Senado e da Câmara, 1635-1650, 1935, p. 55 e 84

${ }^{93}$ No quadro 10 não incluo todas as famílias descendentes de conquistadores.

${ }^{94}$ LISBOA, B., op. cit., t III, p. 145-146)

${ }^{95}$ RIO DE JANEIRO, op. cit., p. 59.

${ }^{96}$ Idem, Ibidem, pp. 61-63.

${ }^{97}$ AHU, ca, doc. 2123-26.

${ }^{98}$ HANSON, C., Economia e Sociedade no Portugal Barroco, Lisboa, Pub. D. Quixote, 1986, p. 239.

${ }^{99}$ LISBOA, B, op. cit., t III, p. 200

${ }^{100}$ AHU, av, cx. 3, doc. 11.

${ }^{101}$ HANSON, op. cit., p. 239; LISBOA, B, op. cit., t III, p. 218

${ }^{102}$ AHU, av, cx. 4, doc. 107

${ }^{103}$ AHU, av, cx.3, doc. 1103.

${ }^{104}$ AHU, RJ., códice 1279; AHU, av, cx. 2, doc. 57

105 AHU, ca, doc. 1571.

${ }^{106}$ AHU, av, cx. 1, doc. 8. 
${ }^{107}$ AHU, av, cx. 2, doc. 57.

${ }^{108}$ Rio de Janeiro, op. cit., 1935, p. 8; AHU, ca, doc. 1814-1819

${ }^{109}$ Rio de Janeiro, op. cit., 1935, p. 8.

${ }^{110}$ Salvador, op. cit., p. 182; AHU, av., cx. 1, doc. 82)

${ }^{111}$ GONÇALO, MONTEIRO, Nuno, in: HESPANHA, A. M. (coord.), op. cit., 1993, pp. 333-370, 1993, p.334; CABRAL de MELLO, , E. 1997, Rubro Veio, Rio de Janeiro: Topbooks 1997, p.167.

${ }^{112}$ Ordenações Filipinas 1985, liv. 1, t. 67, \# 6, p. 155, nota 1; GONÇALO, MONTEIRO, Nuno O Crespúculo dos Grandes (1750-1832), Lisboa, Imprensa Nacional da Casa da Moeda, 1998, pp. 17-32; GONÇALO, MONTEIRO, Nuno "O espaço político e social local”, in: Oliveira, C. (dir.), op. cit., 1996, , pp. 163-164.

${ }^{113}$ Para a ligação entre a noção de principais da terra e conquistadores ver BICALHO, op. cit, 1997, 372-374.

${ }^{114}$ RIO DE JANEIRO, op. cit.; AHU, ca, cx.3, doc. 440-448.

${ }^{115}$ RIO DE JANEIRO, op. cit., p. 77.

${ }^{116}$ AHU, ca, doc. 974.

${ }^{117}$ AHU, av, cx4, doc.94; ca, doc 1332-1339.

${ }^{118}$ HESPANHA,A, “A Fazenda”, in: HESPANHA, A. M. (coord.) op. cit., 1993 p. 225; GODINHO, V, op. cit., 68-69.

${ }^{119}$ GONÇALO, MONTEIRO, Nuno, op. cit., 1998, 227-234 e 503-511.

${ }^{120}$ Idem, Ibidem, pp. 503-517.

${ }^{121}$ AHU, av., cx. 6, doc. 8; AHU, ca, cx3, doc. 440-448.

${ }^{122}$ AHU, av, cx. 2, doc. 57.

${ }^{123}$ AHU, ca, cx. 9,doc. 1670-78.

${ }^{124}$ AHU, av, cx. 5, doc. 74.

${ }^{125}$ AHU, ca, cx. 2, doc. 252-262; AHU, ca, cx. 3, doc. 295.

${ }^{126}$ Em um recente trabalho foi chamada a atenção para a presença de extensas redes sociais de poder que atravessariam o império português. Tais redes envolveriam famílias aristocráticas e suas clientelas nas nomeaçōes régias para os altos cargos da administração civil e militar do ultramar (BETHENCOURT, F, “Configurações do Império”, in: BETHENCOURT, F, op. cit. 1998, 283). Para Goa a existência destas redes já fora indicada por SUBRAHMANYAM, S, op. cit. 326-335). No caso do Rio de Janeiro é importante sublinhar que Salvador Correia de Sá e Benevides teve assento no Conselho Ultramarino, em Lisboa, mantendo ainda diversos interesses na cidade (BOXER, op. cit. 1973). Sobre o tema para o império espanhol ver PEÑA, J., op. cit., p. 215).

${ }^{127}$ Para o tema ver METCALF, Alida, "Fathers and Sons: the ploitics of inheritance in a colonial Brazilian township”, in: Hispanic American Review 66(3): 455-84, 1986; 
NAZZARI, Muriel, Disappearance of dowry, Stanford: Stanford University Press, 1991; e FARIA, Sheila, C., A Colônia em Movimento, Rio de Janeiro, Nova Fronteira, 1998).

${ }^{128}$ FRAGOSO, J., op. cit., 1998.

\section{Resumo}

O ARTIGO ANALISA a formação da primeira elite senhorial do Rio de Janeiro e de sua economia (séculos XVI e XVII). Ele parte do pressuposto de que tal formação se daria em um contexto marcado por dificuldades em Portugal e no seu Ultramar. Em meio a este cenário, os conquistadores utilizariam os velhos elementos, porém eficientes, da antiga sociedade lusa: a conquista (de homens e terras), o Senado da Câmara e o sistema de mercês. Como resultado deste processo, teríamos a formação de uma economia de plantation como derivação de uma hierarquia social e econômica que exclui parte dos colonos.

\section{Abstract}

THE ARTICLE ANALYSES the making of the early seigniorial elite in Rio de Janeiro, as well as its main economic characteristics during the sixteenth and seventeenth centuries. Both centuries were difficult times for Portugal and it's overseas lands. In this scenario the conquerors used the old, but efficient, strategies of the ancient Portuguese society, mainly the conquest (of men and lands), the control of the "senado da câmara" and of the "sistema de mercês". This process resulted in a social and economic hierarchy that excluded part of the colognes and gave birth to the plantation economy. 